\title{
ATUALIDADES E
}

\section{FUNDAMENTOS}

EM REPRODUÇÃO E

DESENVOLVIMENTO

Victor Hugo Vieira Rodrigues

VOLUME 1

\section{ORGANIZADORES}

Aderson Martins Viana

Neto

Máyra Carvalho

Petelinkar
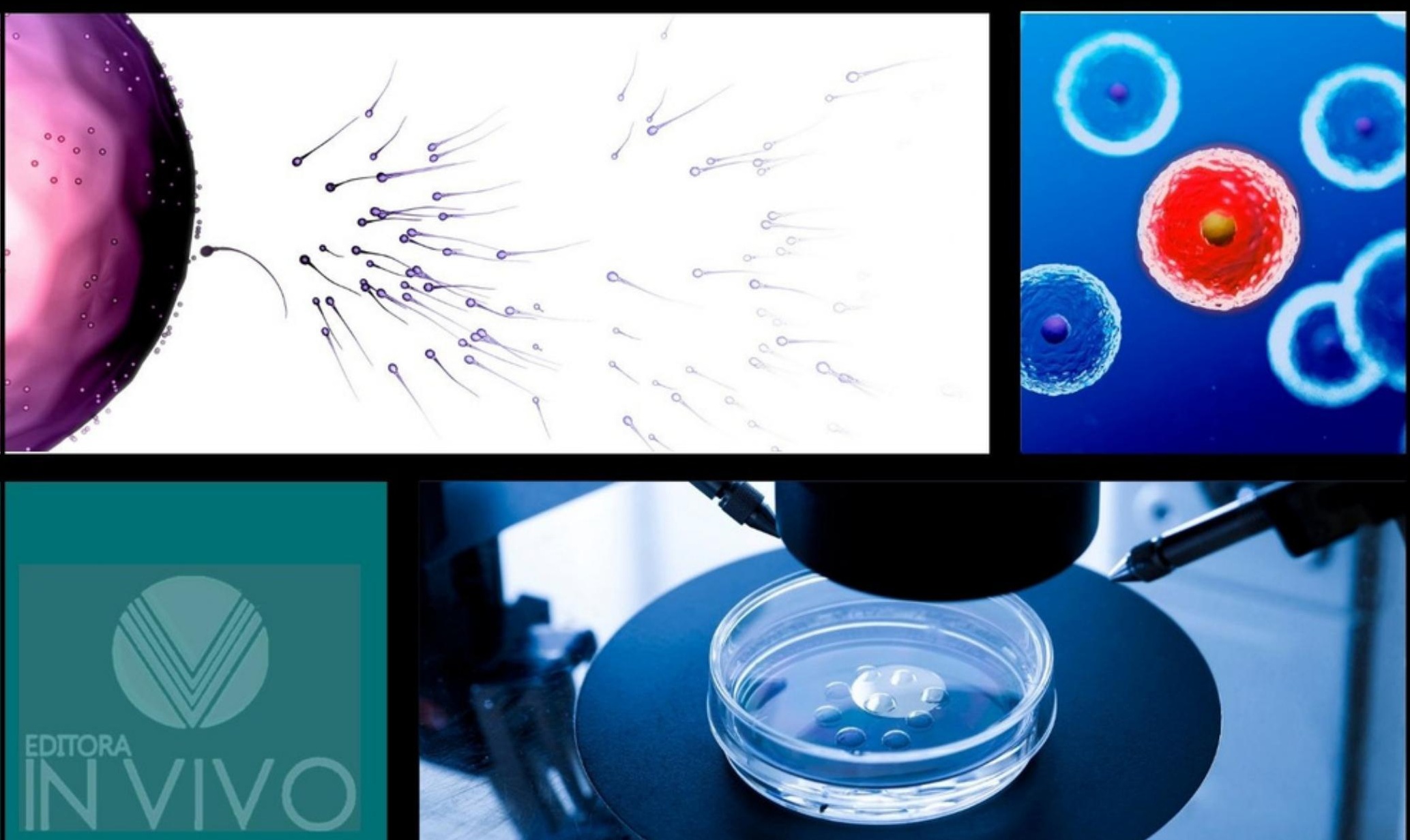
ATUALIDADES E FUNDAMENTOS EM REPRODUÇÃO E DESENVOLVIMENTO

VICTOR HUGO VIEIRA RODRIGUES

ADERSON MARTINS VIANA NETO

MÁYRA CARVALHO PETELINKAR

(Organizadores)

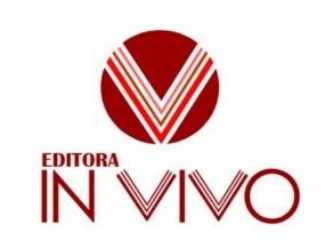

2021 


\author{
2021 by Editora In Vivo \\ Copyright (C) Editora In Vivo \\ Copyright do Texto (C) $2021 \mathrm{O}$ autor \\ Copyright da Edição (C) 2021 Editora In Vivo
}

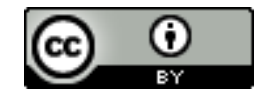

Esta obra está licenciada com uma Licença Creative Commons Atribuição 4.0 Internacional (CC BY 4.0).

O conteúdo desta obra e seus dados em sua forma, correção e confiabilidade são de responsabilidade exclusiva dos autores. Permitido o download da obra e o compartilhamento desde que sejam atribuídos créditos aos autores, permitindo-se uso para fins comerciais.

Editor Chefe

Dr. Everton Nogueira Silva

\section{Colégio de Ciências da Vida 1.1 Ciências Agrárias}

Dr. Aderson Martins Viana Neto

Dra. Ana Paula Bezerra de Araújo

MSc. Edson Rômulo de Sousa Santos

Dr. Fágner Cavalcante P. dos Santos

MSc. Filomena Nádia Rodrigues Bezerra

Dra. Lina Raquel Santos Araújo

Dr. Luis de França Camboim Neto

MSc. Maria Emília Bezerra de Araújo

MSc. Yuri Lopes Silva

\subsection{Ciências Biológicas}

Dra. Antonia Moemia Lúcia Rodrigues Portela

1.3 Ciências da Saúde

Dra. Ana Luiza M. Cazaux de Souza Velho

Dr. Isaac Neto Goes Silva

Dra. Maria Verônyca Coelho Melo

MSc. Paulo Abílio Varella Lisboa

Dra. Vanessa Porto Machado

Dr. Victor Hugo Vieira Rodrigues

\section{Conselho Editorial}

2 Colégio de Humanidades 2.1 Ciências Humanas

Dra. Alexsandra Maria Sousa Silva

MSc. Francisco Brandão Aguiar

MSc. Julyana Alves Sales

2.2 Ciências Sociais Aplicadas

MSc. Cícero Francisco de Lima

MSc. Erivelton de Souza Nunes

Dra. Maria de Jesus Gomes de Lima

MSc. Maria Rosa Dionísio Almeida

MSc. Marisa Guilherme da Frota

3 Colégio de Ciências Exatas, Tecnológica

e Multidisciplinar

3.1 Ciências Exatas e da Terra

MSc. Francisco Odécio Sales

Dra. Irvila Ricarte de Oliveira Maia

3.2 Engenharias

MSc. Amâncio da Cruz Filgueira Filho

MSc. Gilberto Alves da Silva Neto

MSc. Henrique Nogueira Silva

Dr. João Marcus Pereira Lima e Silva

MSc. Ricardo Leandro Santos Araújo

Dados Internacionais de Catalogação na Publicação - CIP

CDD 591 


\begin{abstract}
APRESENTAÇÃO
Este E-book intitulado Atualidades e Fundamentos em Reprodução e Desenvolvimento tem por escopo apresentar a evolução das pesquisas acadêmicas que possam auxiliar nos aspectos clínicos e morfopatologicos da reprodução. Os mais variados e diversos trabalhos acadêmicos, presentes nesta obra, têm por fundamento contemplar os avanços científicos para a área da reprodução e do desenvolvimento, sendo apresentado estudos de grande relevância e contribuição sob novas técnicas e métodos para as áreas tanto da reprodução humana como animal na contemporaneidade da ciência.

Tenham uma boa leitura!

Victor Hugo Vieira Rodrigues

Aderson Martins Viana Neto

Máyra Carvalho Petelinkar
\end{abstract}




\section{Sumário}

\section{SUMÁRIO}

Capítulo 1 - DOI: 10.47242/978-65-993899-8-6-1

CORRELAÇÃO ENTRE DISMORFISMOS OOCITÁRIOS E RESULTADOS DE BIOTÉCNICAS REPRODUTIVAS 06

Capítulo 2 - DOI: 10.47242/978-65-993899-8-6-2

ALTERAÇÕES PATOLÓGICAS DO SISTEMA GENITAL DE PORCAS ABATIDAS NO MUNICÍPIO DE MOSSORÓ, RIO GRANDE DO NORTE. 21

Capítulo 3 - DOI: 10.47242/978-65-993899-8-6-3

TERATOMA MALIGNO OVARIANO EM ÉGUA: ESTUDO DE CASO 45

Capítulo 4 - DOI: 10.47242/978-65-993899-8-6-4

FISIOLOGIA REPRODUTIVA BÁSICA DA FÊMEA CANINA 60

Capítulo 5 - DOI: 10.47242/978-65-993899-8-6-5

INDUÇÃO DE LACTAÇÃO EM NOVILHAS FREEMARTIN- RELATO DE CASO .75

Capítulo 6 - DOI: 10.47242/978-65-993899-8-6-6

CLONAGEM EM BOVINOS: REVISÃO DE LITERATURA .79

Capítulo 7 - DOI: 10.47242/978-65-993899-8-6-7

ASPECTO REPRODUTIVO DO JACARÉ-DE-PAPO-AMARELO

(Caiman latirostris). 96

Capítulo 8 - DOI: 10.47242/10.47242/978-65-993899-8-6-8

AVALIAÇÃO MORFOLÓGICA DE ESPERMATOZOIDES EQUINOS CORADOS COM EOSINA-NIGROSINA E PANÓTICO RÁPIDO. .109 
ÍNDICE REMISSIVO.

.127 


\section{CORRELAÇÃO ENTRE DISMORFISMOS OOCITÁRIOS E RESULTADOS DE BIOTÉCNICAS REPRODUTIVAS}

\section{Anderson Ferreira de Souza}

Centro Universitário Maurício de Nassau, Centro de Saúde, Fortaleza, CE Lattes: http://lattes.cnpq.br/3276022364058901

\section{Ana Íris Pinheiro de Freitas}

Centro Universitário Maurício de Nassau, Centro de Saúde, Fortaleza, CE Lattes: http://lattes.cnpq.br/3712354139828301

\section{Mariana Correia Lima Sales}

Centro Universitário Maurício de Nassau, Centro de Saúde, Fortaleza, CE Lattes: http://lattes.cnpq.br/3070430037650983

\section{Marília Jucá Oliveira}

Centro Universitário Maurício de Nassau, Centro de Saúde, Fortaleza, CE Lattes: http://lattes.cnpq.br/0529334151072488

\section{Milena Erika Pinheiro Saldanha}

Centro Universitário Maurício de Nassau, Centro de Saúde, Fortaleza, CE Lattes: http://lattes.cnpq.br/2017301805653175

\section{José Ryan Ribeiro Tavares}

Centro Universitário Maurício de Nassau, Centro de Saúde, Fortaleza, CE Lattes: http://lattes.cnpq.br/8956703680664291

\section{Máyra Carvalho Petelinkar}

Universidade de Fortaleza, Centro de Ciências da Saúde, Fortaleza, CE http://lattes.cnpq.br/5981111350891482

\section{Dowglish Ferreira Chaves}

Centro Universitário Maurício de Nassau, Centro de Saúde, Fortaleza, CE Lattes: http://lattes.cnpq.br/0898404280553527

\section{Victor Hugo Vieira Rodrigues}

Centro Universitário Maurício de Nassau, Centro de Saúde, Fortaleza, CE Lattes: http://lattes.cnpq.br/2226604565550002

\section{Isadora Machado Teixeira Lima}

Centro Universitário Maurício de Nassau, Centro de Saúde, Fortaleza, CE Lattes: http://lattes.cnpq.br/7247029487214364

Informações sobre o

artigo:

Recebido em:

$24 / 03 / 2021$

Aceito em:

$29 / 03 / 2021$

\section{RESUMO}

Para o sucesso da reprodução assistida, é necessário que haja uma criteriosa seleção dos gametas, o que tornará possível alcançar melhores resultados clínicos. A qualidade do oócito é um fatorchave para a fertilidade feminina, uma vez que reflete no potencial de desenvolvimento do gameta e, consequentemente, no desenvolvimento embrionário. Estudos relataram que cerca de 60 a $80 \%$ dos oócitos maduros apresentam ao menos uma alteração 
Data de publicação:

$19 / 07 / 2021$

Palavras-chave:

Dismorfismo oóctário

Morfologia oócitária

FIV

ICSI

Oócito humano morfológica, também denominada de dismorfismo oocitário. $\mathrm{O}$ objetivo deste trabalho foi promover uma revisão de literatura sobre dismorfismos oócitários e a sua correlação com os resultados de biotecnologias reprodutivas, visto que ainda são escassos estudos mais aprofundados com ênfase nesse tema, viabilizando assim uma atualização. Foi realizada uma pesquisa bibliográfica em plataformas de artigos científicos, como Pubmed e SciELO, utilizando os seguintes descritores: "dismorfismo oocitário", "morfologia oocitária", "FIV", "ICSI", "oócito humano". Os dismorfismos podem ocorrer devido a fatores como idade e problemas genéticos, além de fatores relacionados com o tratamento reprodutivo propriamente dito, como por exemplo, a hiperestimulação ovariana e o ambiente hormonal ao qual o oócito é exposto. Há bastante controvérsias na literatura com relação à classificação da morfologia oocitária e a sua correlação com o desenvolvimento embrionário e a taxa de gravidez definindo o sucesso das biotecnologias reprodutivas.

\section{CORRELATION BETWEEN OOCITARY DYSMORPHISMS AND RESULTS IN REPRODUCTIVE TECHNIQUES}

\section{ABSTRACT}

For the success of assisted reproduction, it is necessary that there is a careful selection of gametes, which will make it possible to achieve better clinical results. Oocyte quality is a key factor for female fertility, since it reflects on the gamete's development potential and, consequently, on embryonic development. Studies related that about 60 to $80 \%$ of mature oocytes present at least one morphological alteration, also called oocyte dysmorphism. The objective of this work was to promote a literature review on oocyte dysmorphisms and their correlation in the results of reproductive biotechnologies, since there is still a lack of more in-depth studies with an emphasis on this theme, thus enabling an update. To this end, a bibliographic search was carried out on platforms of scientific articles, such as Pubmed and SciELO, with descriptors: "oocyte dysmorphisms", "oocitary morphology", "IVF", "ICSI", "human oocyte". Dysmorphisms can occur due to factors such as age and genetic problems, in addition to factors related to reproductive treatment itself, such as ovarian hyperstimulation and the hormonal environment to which the oocyte is exposed. There is much controversy in the literature regarding the classification of oocyte morphology and its correlation with embryonic development and the pregnancy rate defining the success of reproductive biotechnologies.

Keywords:

Oocyte dysmorphisms

Oocitary morphology

IVF

ICSI

Human oocyte 


\section{INTRODUÇÃO}

Para o sucesso da reprodução assistida, é necessário que haja uma criteriosa seleção dos gametas, o que tornará possível alcançar melhores resultados clínicos. Dismorfismos oocitários são classificados basicamente em dois tipos: extracitoplasmáticos e citoplasmáticos (GILCHRIST et al., 2008).

Dismorfismos extracitoplasmáticos são anormalidades ligadas à forma oocitária (formato irregular do oócito em metáfase II meiótica), anormalidades na zona pelúcida (alterações em sua coloração e espessura), e também anormalidades no espaço perivitelino (aumento desse espaço, presença de granulações). Dismorfismos citoplasmáticos são anormalidades ligadas ao citoplasma do oócito, as quais envolvem presença de variações de granulação e de cor (granulação parcial ou total do citoplasma, coloração escura), presença de corpos refráteis, aglomerados de retículo endoplasmático liso, ou presença de vacúolos no ooplasma (BALABAN E URMAN, 2006).

Os dismorfismos podem ocorrer devido a fatores como idade e problemas genéticos, além de fatores relacionados com o tratamento reprodutivo propriamente dito, como por exemplo, a hiperestimulação ovariana e o ambiente hormonal ao qual o oócito é exposto. Há bastante controvérsias na literatura com relação à classificação da morfologia oocitária e a sua correlação com o desenvolvimento embrionário e a taxa de gravidez. Alguns estudos, por exemplo, não indicam associação da morfologia oocitária com resultados de técnicas de reprodução, enquanto outros apontam relação entre a qualidade oocitária e o desenvolvimento embrionário (SETTTI et al., 2011).

Tendo como base tais apontamentos e estudos, podemos observar que há ainda uma carência de informações e pesquisas mais aprofundadas e atuais sobre o tema. Desta forma, o objetivo deste trabalho foi realizar uma revisão bibliográfica qualitativa a fim de acrescentar novos achados literários sobre dismorfismos oocitários e sua correlação com biotécnicas reprodutivas, permitindo uma abordagem mais atualizada sobre o assunto.

\section{MATERIAIS E MÉTODOS}

Foi adotado para essa pesquisa um método de revisão de literatura qualitativa e narrativa embasada em artigos, jornais científicos e livros, utilizando os descritores: “dismorfismo oocitário", “morfologia oocitária”, "FIV”, "ICSI”, “oócito humano”. A busca dos artigos científicos foi realizada por meio das plataformas digitais SciELO e Pubmed entre 
os meses de fevereiro e novembro do ano de 2020. No total, foram utilizados para a pesquisa 25 artigos, dois livros e três jornais científicos.

\section{RESULTADOS E DISCUSSÃO}

\subsection{Oócito e sua Morfologia}

A oogênese é a sequência de eventos pelos quais as oogônias, células germinativas primordiais presentes nos ovários, são transformadas em oócitos maduros. Todas as oogônias se desenvolvem em oócitos primários antes do nascimento, ainda na fase fetal do desenvolvimento gestacional da mulher. O oócito é envolvido pela zona pelúcida e por uma camada de células foliculares, a corona radiata. Os hormônios FSH e LH produzem mudanças cíclicas nos ovários - o ciclo ovariano - resultando no desenvolvimento dos folículos, na ovulação (liberação de um oócito de um folículo maduro) e na formação do corpo lúteo. Durante cada ciclo, o FSH estimula o desenvolvimento de vários folículos primários, aproximadamente de 5 a 12 folículos primários; entretanto, somente um folículo primário normalmente chega ao estágio de folículo maduro e se rompe na superfície ovariana, expelindo seu oócito (MOORE; PERSAUD; TORCHIA, 2006).

Oócitos considerados morfologicamente normais devem apresentar: forma esférica; citoplasma transparente moderadamente granular e livre de inclusões; pequeno espaço perivitelino (EPV), livre de granulações, contendo um único corpúsculo polar redondo e intacto; zona pelúcida (ZP) clara e de espessura apropriada (SWAIN; POOL, 2008).

\subsection{Maturação e Qualidade Oocitária}

A maturação oocitária é um processo longo e bastante complexo. Nele há diversas interações e mudanças nucleares e citoplasmáticas, que resultam na transição de vesícula germinativa em metáfase II e no aparecimento do primeiro corpúsculo polar. As células do cumulus também contribuem para a produção de substâncias que promovem a maturação de oócitos (LOUTRADIS et al., 2006).

A maturação oocitária envolve não apenas alterações relacionadas a eventos nucleares, mas também alterações citoplasmáticas que ocorrem de maneira coordenada, de 
modo que a maturidade nuclear não pode ser considerada sinônimo de competência oocitária, por não refletir a maturidade citoplasmática (EBNER et al., 2006).

Já a maturação citoplasmática é um processo durante o qual vários fenômenos ocorrem no citoplasma do oócito que, paralelamente à maturação nuclear, preparam o oócito para a fecundação e suportam o desenvolvimento embrionário inicial. A qualidade do oócito depende da sua maturação citoplasmática. Oócitos com maturação citoplasmática insuficiente ou defeituosa são incapazes de ser fertilizados e se desenvolverem (LOUTRADIS et al., 2006).

Dessa forma, deficiências no processo de maturação citoplasmática podem comprometer todos os processos que preparam o oócito para ativação, adequada fertilização e desenvolvimento embrionário. Além das deficiências do processo, a assincronia nos eventos de maturação nuclear e citoplasmática foi associada à ocorrência de dismorfismos oocitários (KRISHER, 2004).

\subsection{Oócitos e Biotécnicas Reprodutivas}

O oócito é utilizado em importantes métodos de reprodução humana como, ICSI (Injeção intracitoplasmática de espermatozoides) e FIV (Fecundação in vitro), correspondendo a um dos fatores primários para o sucesso dessas biotecnologias, o que vai depender diretamente da qualidade oocitária.

A técnica de ICSI foi introduzida em 1992, visando suprir as deficiências em fertilização oriundas de fatores masculinos, como alterações de concentração, morfologia espermática e motilidade, se tornando, assim, umas das principais técnicas e métodos de reprodução humana. Essa técnica consiste na introdução de um espermatozóide no citoplasma do oócito, seguida do acompanhamento do posterior desenvolvimento embrionário (PALERMO et al., 1992).

Durante o procedimento de ICSI, é realizada a injeção de um único espermatozóide devidamente selecionado em um oócito maduro, ultrapassando a zona pelúcida do oócito e introduzindo-o no oolema (citoplasma oocitário). A vantagem da ICSI em relação à FIV, é que a ICSI garante in vitro a realização de muitas etapas do processo de fertilização, ou seja, a ligação do espermatozoide e a penetração deste na zona pelúcida e a sua posterior fusão com o oolema. Como desvantagem, a ICSI pode permitir a fertilização do oócito por espermatozoides com propriedades cinéticas deficientes ou anomalias do acrossoma (PALERMO et al., 1992). 
Quanto à FIV, esta também é uma técnica que viabiliza a fertilização caso haja deficiências de fatores masculinos. Consiste em tratamento do oócito e do espermatozóide para que seja realizada a fecundação em laboratório, originando, a partir dessa técnica, um embrião (BHATTACHARYA et al., 2001).

As etapas envolvidas durante a FIV e a transferência de embriões são as seguintes: os folículos ovarianos são estimulados a se desenvolverem e a amadurecerem pela administração de citrato de clomifeno ou gonadotrofina (superovulação). Vários oócitos maduros são então aspirados de folículos ovarianos maduros durante uma laparoscopia. Os oócitos também podem ser colhidos de dentro dos folículos por uma agulha guiada por ultrassonografia inserida através da vagina. Após a colheita dos oócitos, estes são colocados em uma placa de Petri contendo um meio de cultura especial e espermatozóides capacitados. A fertilização dos oócitos e a clivagem dos zigotos são monitoradas microscópicamente por 3 a 5 dias. Dependendo da idade da mãe, de um a três embriões formados (no estágio de quatro a oito células ou blastocistos iniciais) são transferidos para o interior do útero introduzindo-se um cateter através da vagina e do colo uterino. Qualquer embrião remanescente é armazenado em nitrogênio líquido para uso posterior (MOORE; PERSAUD; TORCHIA, 2006).

Vale ressaltar que há estudos que sugerem que o sucesso do desenvolvimento do embrião no útero após a sua transferência está diretamente relacionado à ausência de dismorfismos nos oócitos utilizados para a FIV (BALABAN E URMAN, 2006).

\subsection{Classificação dos Dismorfismos Oocitários e suas Características}

Os dismorfismos oocitários, que consistem em alterações morfológicas e/ou estruturais do oócito, são usualmente classificados em dois grupos: extracitoplasmáticos e intracitoplasmáticos. Em suas definições, consiste em dismorfismo extracitoplasmático a presença de alterações no tamanho do oócito, presença de alterações no espaço perivitelino, granulações corticais na zona pelúcida, bem como na sua espessura e coloração, e alterações morfológicas do corpúsculo polar, como tamanho anormal ou fragmentação. Já nos dismorfismos intracitoplasmáticos, pode se encontrar granulações e/ou inclusões citoplasmáticas, tais como corpos refrativos, vacúolos e agregados de retículo endoplasmático liso (RIENZI et al., 2012). 
A qualidade oocitária é um dos principais fatores que afetam a fertilidade, e a ocorrência de alterações extracitoplasmáticas e/ou intracitoplasmáticas durante o processo de maturação do oócito pode acarretar em falhas na fertilização, aneuploidia cromossômica, e alterações no desenvolvimento embrionário (RIENZI et al., 2008).

\subsection{Dismorfismos Extracitoplasmáticos}

\subsubsection{Zona pelúcida}

A zona pelúcida é uma matriz multilaminar composta por glicoproteínas, polissacarídeos e proteínas específicas, com aproximadamente 15-20 $\mu \mathrm{m}$ de espessura, que envolve o oócito e o embrião no início do desenvolvimento (PELLETIER et al., 2004).

A estrutura da zona pelúcida se forma durante a maturação do oócito pelo folículo e, em parte, pelas células da granulosa. A formação e a organização das proteínas específicas da zona pelúcida durante a maturação oocitária podem refletir na competência do oócito (MONTAG et al., 2011).

Os dismorfismos característicos na zona pelúcida estão relacionados à sua espessura (grossa ou fina) e também à sua coloração (escura) (SOUSA et al., 2013) (Figura 1).

Figura 1 - Oócito com zona pelúcida espessa

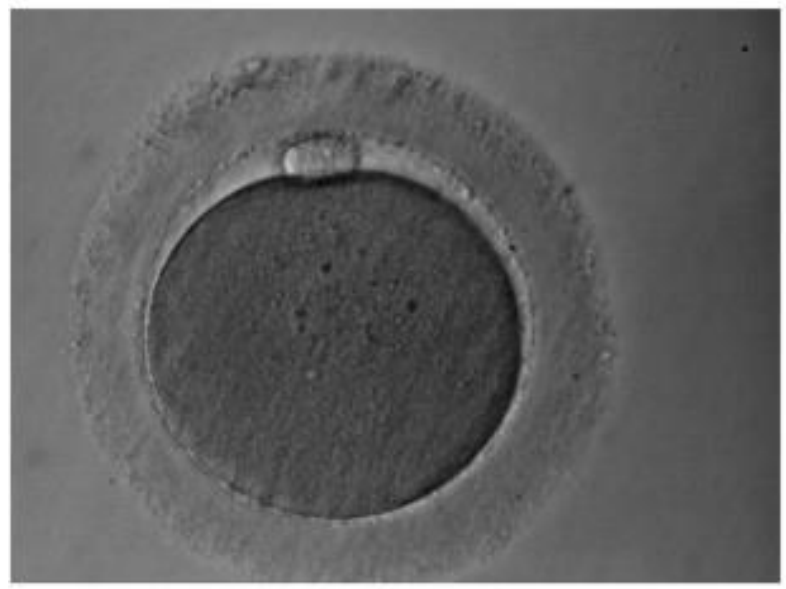

Fonte: Ashrafi et al. (2015) 


\subsubsection{Espaço perivitelino}

O espaço perivitelino consiste em uma fluida estrutura que se localiza entre a membrana plasmática do oócito e a zona pelúcida. Seu espaço pode variar em termos de tamanho e conteúdo, o que pode apontar o grau de maturação do oócito. Em oócitos maduros, o espaço perivitelino apresenta um grau de expansão maior em comparação com oócitos imaturos (MIKKELSEN,LINDENBER, 2001).

Um estudo mostrou que a probabilidade de um oócito ser fertilizado é significativamente reduzida na presença de um espaço perivitelino aumentado (Figura 2), embora os efeitos sobre a implantação e as taxas de gravidez permaneçam obscuros (SETTI, 2011). Já a presença de granulação no espaço perivitelino (Figura 3) foi associada negativamente às taxas de implantação e gravidez em ciclos em que toda a coorte de oócitos é afetada, embora ressalta-se que o número de ciclos analisados tenha sido limitado (FARHI et al., 2002).

Figura 2 - Oócito com espaço perivitelino aumentado e corpúsculo polar fragmentado

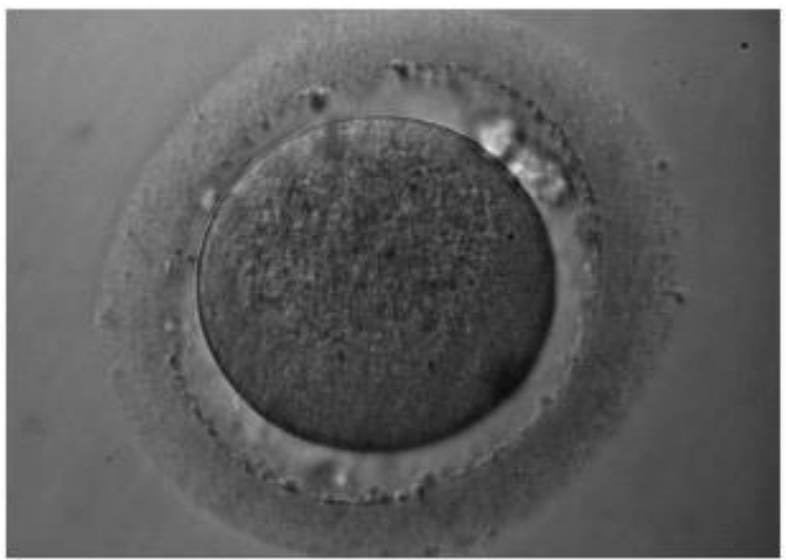

Fonte: Ashrafi et al. (2015) 
Figura 3 - Granulação no espaço perivitelino

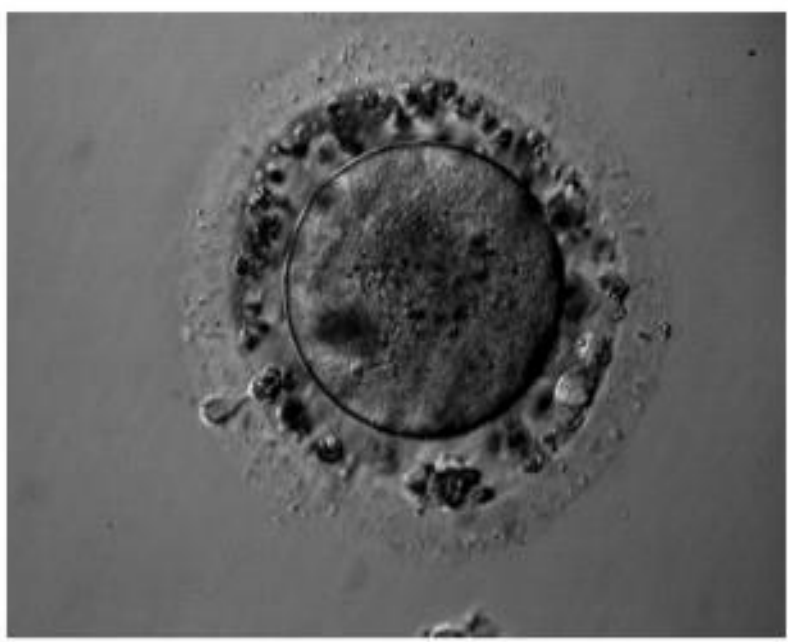

Fonte: Ashrafi et al. (2015)

\subsubsection{Corpúsculo polar}

O primeiro corpúsculo polar a ser apresentado no oócito é uma célula-filha que apresenta 23 cromossomos e 46 cromátides, que é gerado após a telófase da primeira divisão meiótica. Os critérios de formação do primeiro corpúsculo polar, como tamanho, forma e integridade poderão ser utilizados para predição da qualidade oocitária (EBNER et al., 2006) (Figura 4).

Considerando também o fator tempo, acredita-se que a morfologia do primeiro corpúsculo polar pode oferecer informações a respeito da idade pós-ovulatória do oócito, apesar de que alguns corpúsculos polares permanecem intactos por mais de 20 horas após a ovulação. Em geral, após esse tempo as estruturas apresentam sinais de degeneração e fragmentação. O aumento do tamanho do corpúsculo polar pode ser considerado o principal dismorfismo associado a ele, estando relacionado com o aumento de incidência de aneuploidia oocitária (FANCSOVITS et al., 2006). 
Figura 4 - Corpúsculo polar fragmentado

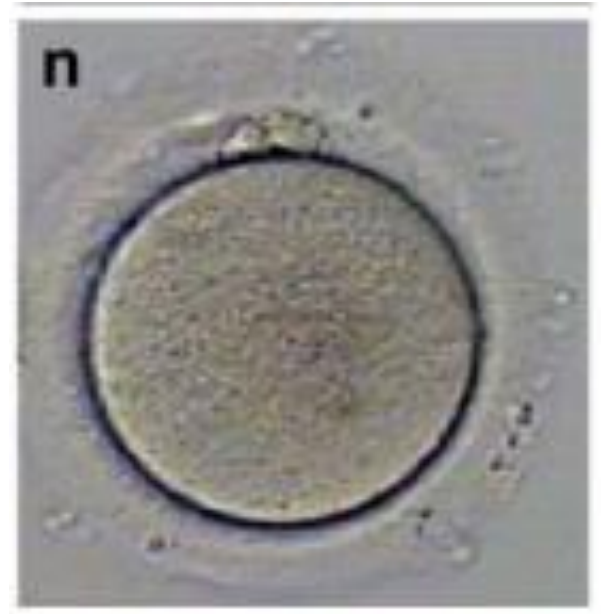

Fonte: Halvae et al. (2012)

\subsection{Dismorfismos Citoplasmáticos}

\subsubsection{Granulação}

O aumento de granulação pode ocorrer de forma homogênea, ou seja, afetando todo o citoplasma, ou centralizadas, sendo o aumento de granulação considerado o principal fator que leva a uma baixa viabilidade oocitária (KAHRAMAN et al., 2000;) (Figuras 5 e 6).

O citoplasma granular é uma característica morfológica rara do oócito, mas que pode ser observada em alguns casos. É diagnosticada como uma área granular esponjosa, escura e maior. A granularidade citoplasmática de um oócito pode ser homogênea ou de localização central, conforme citado acima, podendo ser também leve ou severa. A gravidade da granularidade é baseada no diâmetro da área granular e na profundidade da lesão (KAHRAMAN et al., 2000).

Figura 5 - Oócito com granulação central no citoplasma

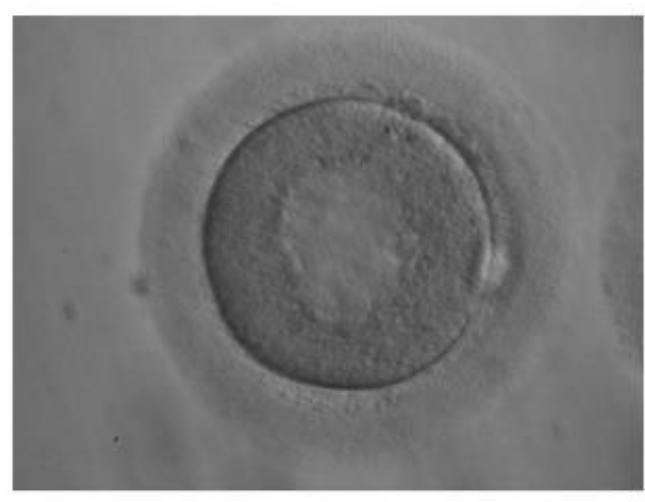

Fonte: Ashrafi et al. (2015) 
Figura 6 - Oócito com granulação geral do citoplasma

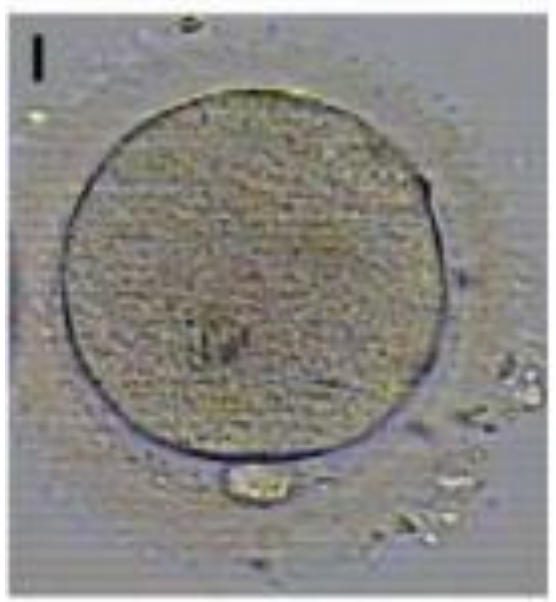

Fonte: Halvae et al. (2012)

\subsubsection{Inclusões}

Há diversos tipos de inclusões que podem ser observadas no citoplasma de oócitos avaliados em microscopia de luz. Os corpos refráteis são estruturas de aproximadamente 10 $\mu \mathrm{m}$ de diâmetro e são compostos por material lipídico e grânulos densos. Vacúolos são inclusões citoplasmáticas rodeadas por uma membrana que podem variar quanto ao número e tamanho, e acredita-se que podem aparecer de forma espontânea ou por interferências de fusões de vesículas oriundas de retículo endoplasmático liso e/ou do complexo de Golgi (EL SHAFIE et al., 2000).

Entretanto, o mecanismo de surgimento de agregados do retículo endoplasmático liso é de origem desconhecida. A diferenciação destas estruturas se dá pelo fato de que os agregados de retículo endoplasmático liso são estruturas translúcidas, não delimitadas por membranas (EBNER et al., 2006; RIENZI et al., 2012).

Estudos apontam que não há uma direta interferência na qualidade oocitária pela presença de algumas inclusões, como corpos refrateis, mas notam que a presença de vacúolos e de agregados de retículo endoplasmático liso é um fator que pode promover a inviabilidade oocitária humana (EBNER et al., 2006;) (Figuras 7 e 8).

Como consequência, os defeitos no citoplasma afetariam a formação e também o posicionamento dos pró-núcleos, tendo em vista que o citoesqueleto estaria sendo afetado, não podendo organizar-se perfeitamente, vindo a afetar então o posicionamento do fuso meiótico durante a retomada da meiose. Com isso, inviabilizaria o conjunto de eventos da fertilização, que envolve liberação de cálcio e grânulos corticais, síntese de proteínas e alterações do citoesqueleto (DOZORTSEV et al., 2005). 
Figura 7 - Oócito com presença de vacúolo. Fonte: Ashrafi et al. (2015)

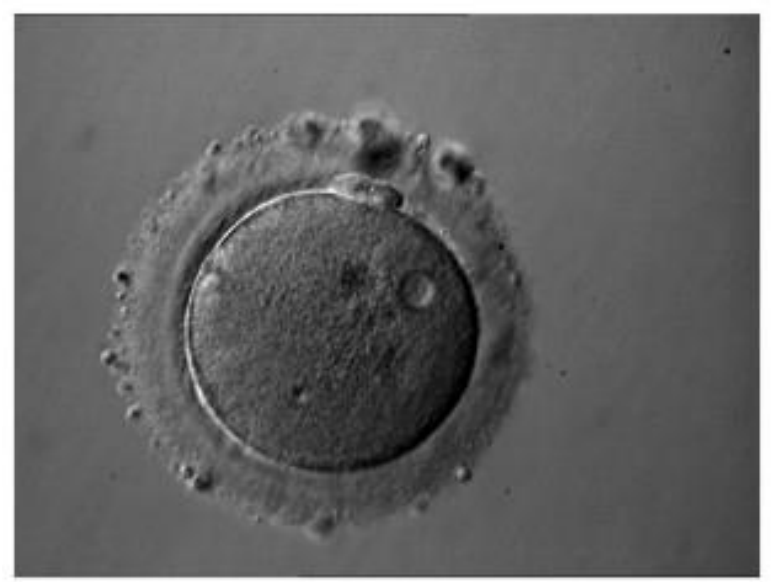

Fonte: Ashrafi et al. (2015)

Figura 8 - Oócito com presença de corpos refráteis

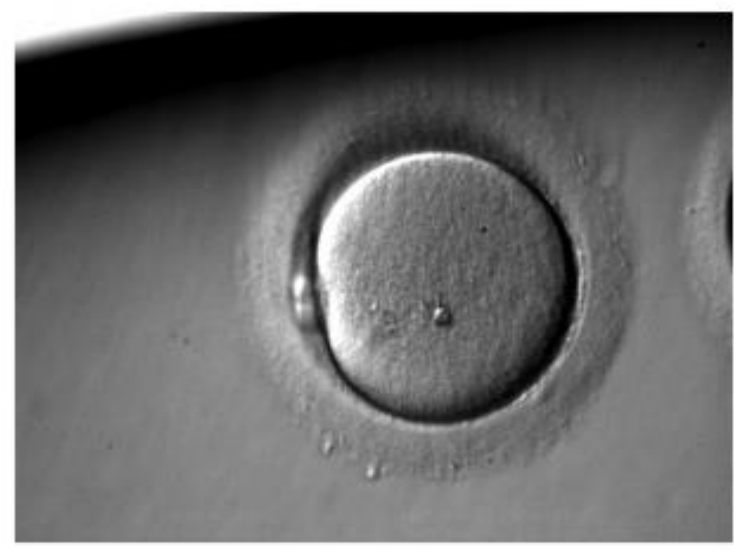

Fonte: Ashrafi et al. (2015)

\section{CORRELAÇÃO ENTRE DISMORFISMOS OOCITÁRIOS E RESULTADOS DAS BIOTECNOLOGIAS REPRODUTIVAS}

Achados de Balaban e Urman (2006) sugeriram que os dismorfismos extracitoplasmáticos devem ser considerados apenas um desvio fenotípico resultante da heterogeneidade dos oócitos recuperados. Já os dismorfismos citoplasmáticos graves, como agregados de retículo endoplasmático liso, granulação central grave e vacuolização excessiva, devem ser considerados anormais e levados em consideração para a seleção de um oócito viável. 
Em uma conferência sobre estudos em reprodução humana, realizada em 2011, foi acordado que uma nota tanto do espaço perivitelino como do tamanho do corpúsculo polar só deve ser feita se eles forem excepcionalmente grandes. Além disso, a observação de vacúolos grandes ( $>14 \mathrm{~mm}$ de diâmetro) deve ser observada.

Rienzi et al. (2010) relataram que anormalidades no corpúsculo polar reduziram significativamente pela metade a chance de fertilização do oócito. Foi proposto que a extrusão de um grande corpúsculo polar se deve ao deslocamento do fuso meiótico e está associada a um aumento da taxa de fertilização anormal.

Setti et al. (2011) demonstraram ainda que a presença de um grande espaço perivitelino reduz significativamente a chance de fertilização do oócito. Esse achado está de acordo com o estudo de Rienzi et al. (2008), que observaram uma diminuição significativa da fertilização na presença dessa anormalidade morfológica. Da mesma forma, Figueira et al. (2010) relataram que a taxa de fertilização foi significativamente afetada pela presença de grande espaço perivitelino. Além disso, observou-se uma redução significativa na probabilidade de fertilização quando encontradas inclusões nos oócitos, como vacúolos e corpos refráteis.

\section{CONCLUSÃO}

Podemos concluir que apesar de haver atualmente grandes avanços na medicina reprodutiva e suas tecnologias, a correlação da morfologia oocitária com os resultados destas biotecnologias ainda é um fator que carece de estudos mais específicos e aprofundados, pois ainda há uma forte contradição nesse sentido na literatura. Tal fato justifica ainda mais a necessidade de atualização sobre o tema, a fim de buscar um consenso geral e unânime, bem como desenvolver um padrão para a avaliação morfológica, visando atingir ao máximo resultados positivos nestas biotecnologias.

\section{REFERÊNCIAS}

ASHRAFI, Mahnaz; et al. Effect of oocyte dysmorphisms on intracytoplasmic sperm injection cycle outcomes in normal ovarian responders. The Journal of Obstetrics and Gynaecology Research, v. 41, n. 12, p. 1912-1920, dez. 2015.

BALABAN, B.; URMAN, B. Effect of oocyte morphology on embryo development and implantation. Reproductive Biomedicine Online, v. 12, n. 5, p. 606-615, mai. 2006. 
BHATTACHARYA, S.; et al. Conventional in vitro fertilisation versus intracytoplasmic sperm injection for the treatment of non-male-factor infertility: a randomised controlled trial. Lancet, v. 357, n. 9274, p. 2075-2079, jun. 2001.

DOZORTSEV, D.; et al. Human oocyte activation following intracytoplasmic injection: the role of the sperm cell. Human Reproduction, v. 10, n. 2, p. 403-407, fev. 1995.

EBNER, T.; MOSER, M.; TEWS, G. Is oocyte morphology prognostic of embryo developmental potential after ICSI? Reproductive Biomedicine Online, v. 12, n. 4, p. 507512, abr. 2006.

EL SHAFIE, M.; et al. Ultrastructure of human oocytes: a transmission electron microscopic view. In: El Shafie M, Sousa M, Windt ML, Kruger TF, editors. An atlas of the ultrastructure of human oocytes a guide for assisted reproduction. London: CRC Press; 2000. p. 151-71. (Encyclopedia of Visual Medicine Series).

FANCSOVITS, P.; et al. Correlation between first polar body morphology and further embryo development. Acta Biologica Hungarica, v. 57, n. 3, p. 331-338, set. 2006.

FARHI, J.; et al. Coarse granulation in the perivitelline space and IVF-ICSI outcome. Journal of Assisted Reproduction and Genetics, v. 19, n. 12, p. 545-549, dez. 2002.

GILCHRIST R. B.; LANE M.; THOMPSON J. G. Oocyte-secreted factors: regulators of cumulus cell function and oocyte quality. Human Reproduction Update, v. 14, n. 2, p. 159-177, 2008.

HALVAEI, Iman; et al. The effect of immature oocytes quantity on the rates of oocytes maturity and morphology, fertilization, and embryo development in ICSI cycles. Journal of Assisted Reproduction and Genetics, v . 29, n. 8, p. 803-810, ago. 2012.

KAHRAMAN S.; et al. Relationship between granular cytoplasm of oocytes and pregnancy outcome following intracytoplasmic sperm injection. Human Reproduction v. 15, n. 11, p. 2390-2393, nov. 2000.

KRISHER, R. L. The effect of oocyte quality on development. Journal of Animal Science, v. 82, n. 13 , p. 14-23, jan. 2004.

LOUTRADIS, Dimitris; et al. Oocyte Maturation in Assisted Reproductive Techniques. Annals New York Academy of Sciences, v. 1092, n. 1, p. 235-246, dez. 2006.

MIKKELSEN, A. L.; LINDENBERG, S. Morphology of in-vitro matured oocytes: impact on fertility potential and embryo quality. Human Reproduction, v. 16, n. 8, p. 1714-1718, ago. 2001.

MONTAG, M.; et al. Gamete competence assessment by polarizing optics in assisted reproduction. Human Reproduction Update, v. 17, n. 5, p. 654-666, 2011.

MOORE, Keith L.; PERSAUD, T.V.N.; TORCHIA, Mark G. Embriologia Clínica. $10^{\circ}$ Edição. Rio de Janeiro: Elsevier Editora Ltda. 2006. 
PALERMO, G.; et al. Pregnancies after intracytoplasmic injection of single spermatozoon into an oocyte. Lancet, v. 340, n. 8810, p. 17-18, jul. 1992.

PELLETIER, C.; KEEFE, D. L.; TRIMARCHI, J. R. Noninvasive polarized light microscopy quantitatively distinguishes the multilaminar structure of the zona pellucida of living human eggs and embryos. Fertility and Sterility, v. 81, n. 1, p. 850-856, mar. 2004.

RIENZI, L.; et al. Significance of metaphase II human oocyte morphology on ICSI outcome. Fertility and Sterility, v. 90, n. 5, p. 1692-1700, nov. 2008.

RIENZI, L.; VAJTA, G.; UBALDI, F. Predictive value of oocyte morphology in human IVF: a systematic review of the literature. Human Reproduction Update, v. 17, n. 1, p. 3445, 2011.

RIENZI, L.; et al. The oocyte. Human Reproduction, v. 27, n. 1, p. 2-21, ago. 2012.

SETTI A.S.; et al. Relationship between oocyte abnormal morphology and intracytoplasmic sperm injection outcomes: a meta-analysis. European Journal of Obstetrics, Gynecology and Reproductive Biology, v. 159, n. 2, p. 364-370, dez. 2011.

SOUSA, M.; et al. Embryological, clinical and ultrastructural study of human oocytes presenting indented zona pelúcida. Cambridge University Press, set. 2013.

SWAIN J. E.; POOL T. B. ART failure: oocyte contributions to unsuccessful fertilization. Human Reproduction Update, v. 14, n. 5, p. 431-446, 2008. 


\section{ALTERAÇÕES PATOLÓGICAS DO SISTEMA GENITAL DE PORCAS ABATIDAS NO MUNICÍPIO DE MOSSORÓ, RIO GRANDE DO NORTE}

\section{Carla Monadeli Filgueira Rodrigues}

Universidade de São Paulo (USP), Laboratório de Filogenia e Taxonomia de Tripanossomatídeos da Universidade de São Paulo, São Paulo, SP

Lattes: http:/ /lattes.cnpq.br/1707230625144268

\section{Jael Soares Batista}

Universidade Federal Rural do Semiárido (UFERSA), Centro de Ciências Agrárias, Mossoró, RN Lattes: http://lattes.cnpq.br/4937343270124186

\section{Lorena Santos Bezerra}

Universidade de Fortaleza (UNIFOR), Centro de Ciências da Saúde, Fortaleza, CE

Lattes: http://lattes.cnpq.br/4384719184797527

\section{Soraya Kelly de Sousa Veloso}

Centro Universitário Maurício de Nassau (UNINASSAU), Centro de Saúde, Fortaleza, CE

Lattes: http://lattes.cnpq.br/3414562367937356

\section{Máyra Carvalho Petelinkar}

Universidade de Fortaleza (UNIFOR), Centro de Ciências da Saúde, Fortaleza, CE

Lattes: http://lattes.cnpq.br/5981111350891482

\section{Victor Hugo Vieira Rodrigues}

Centro Universitário Maurício de Nassau (UNINASSAU), Centro de Saúde, Fortaleza, CE

Lattes: http://lattes.cnpq.br/2226604565550002

Informações sobre o

artigo:

Recebido em:

$06 / 04 / 2021$

Aceito em:

10/04/2021

Data de publicação:

19/07/2021

Palavras-chave:

Patologia

Sistema reprodutor

Abate

Suínos

\section{RESUMO}

A eficácia produtiva em um sistema de exploração de suínos está relacionada à eficiência reprodutiva, medida pelo número de leitões produzidos por fêmea ao ano. Os órgãos que compõem o sistema reprodutivo são sujeitos a lesões infecciosas, traumáticas e neoplásicas, que resultam em alterações histológicas e funcionais. Objetivou-se neste trabalho identificar as patologias mais comuns no aparelho genital de fêmeas suínas abatidas, a fim de estudar a natureza, localização, e a frequência das alterações histológicas e macroscópicas destas doenças. Foram examinados tratos reprodutivos de 169 cadáveres de fêmeas não prenhes (grupo um) e prenhes (grupo dois), fixadas em formol 10\%, seguido pela análise das amostras de forma macroscópica e histológica. Observou-se que $73 \%$ das fêmeas do grupo um possuíam alterações patológicas, e a patologia mais frequente deste grupo foi a presença de cistos paraováricos. No entanto, o grupo dois apresentou grande frequência de fetos macerados, seguido de fetos mumificados. Concluiu-se, portanto, que as patologias mais frequentes foram de origem cística, inflamatória, de 
desenvolvimento e crescimento celular, assim como também patologias do útero gestante.

PATHOLOGICAL CHANGES IN THE GENITAL SYSTEM OF SLAUGHTERED SOWS IN THE MUNICIPALITY OF MOSSORÓ, RIO GRANDE DO NORTE

\section{ABSTRACT}

The productive efficiency in a pig farming system is related to reproductive efficiency, measured by the number of piglets calculated per female per year. The organs that make up the reproductive system are subject to infectious, traumatic and neoplastic lesions, which result in histological and functional changes. The objective of this work was to identify the most common pathologies in the genital apparatus of slaughtered swine females, in order to study the nature, location, and the frequency of histological and macroscopic changes in these diseases. Reproductive tracts of 169 cadavers of non-pregnant females (group one) and pregnant (group two), fixed in 10\% formaldehyde, were examined, followed by the analysis of the samples in a macroscopic and histological form. It was observed that $73 \%$ of the females in group one had pathological changes, and the most frequent pathology in this group was the presence of paraovarian cysts. However, group two showed a high frequency of macerated fetuses, followed by mummified fetuses. It was concluded, therefore, that the most frequent pathologies were of cystic, inflammatory, development and cell growth, as well as pathologies of the pregnant uterus.

\section{INTRODUÇÃO}

A eficiência produtiva em um sistema de exploração de suínos está diretamente relacionada à eficiência reprodutiva, medida pelo número de leitões produzidos por fêmea por ano (DIAL et al., 1994). Esse índice é influenciado diretamente pelo número de partos que cada matriz produz ao ano e pelo número de leitões desmamados por leitegada (WENTZ et al., 2001).

As taxas elevadas de remoção de matrizes além do potencial prejuízo em eficiência reprodutiva, também possuem impacto econômico, sendo associado com elevação nos custos variáveis com reposição de plantel, aumento nos custos por leitão desmamado e redução na lucratividade (SEHESTED, 1996). Em função do intenso fluxo de produção, as taxas anuais de remoção (descarte e mortalidade) e reposição de matrizes em granjas comerciais de suínos são próximas de 50\%, de acordo com Engblom et al. (2007). 
O desempenho reprodutivo insatisfatório pode ser causado por microrganismos específicos, mas em geral deve-se a fatores relacionados ao ambiente (climáticos e instalações), genéticos, de sanidade, de nutrição e de manejo. Assim, o diagnóstico da falha reprodutiva de origem multifatorial é complexo e a identificação dos fatores envolvidos necessita de avaliação abrangente no sistema de produção, que pode ser feito por meio de estudos ecopatológicos realizados nas próprias criações onde os fatos ocorrem espontaneamente (MADEC e JOSSE, 1984).

Por ocasião do estudo dos órgãos genitais femininos coletados após abate, há evidência dos reais motivos que desencadeiam o transtorno reprodutivo como causa de descarte de fêmeas suínas (VARGAS et al., 2005). Assim, objetivou-se neste trabalho identificar as patologias mais comuns no aparelho genital de fêmeas suínas abatidas, a fim de estudar a natureza, localização, e a frequência das alterações histológicas e macroscópicas destas doenças.

\section{MATERIAL E MÉTODOS}

\subsection{Coleta e processamento das amostras}

Foi avaliado, semanalmente, de fevereiro a agosto de 2008, o trato genital feminino de suínos prenhes e não prenhes provenientes do Abatedouro frigorífico de Mossoró AFIM. Após o abate, os sistemas genitais foram removidos das carcaças, dissecados e examinados de acordo com metodologia descrita por Rosa et al. (1978). O trato genital foi encaminhado ao Laboratório de Patologia Veterinária da Universidade Federal Rural do Semiárido - UFERSA, onde foi inicialmente identificado e feito a análise macroscópica deles. Os animais que não se apresentavam gestantes, foram denominados de grupo 1 ( $\mathrm{n}=92)$ e aqueles que estavam gestantes de grupo $2(n=77)$.

Os órgãos do sistema genital foram avaliados quanto à anatomia, cor, volume, consistência e conteúdo. Os genitais que apresentaram algum tipo de alteração macroscópica foram fotografados, sendo posteriormente coletadas amostras de aproximadamente $1,5 \mathrm{~cm}$, as quais foram fixadas em formol tamponado a $10 \%$ e em seguida conservadas em álcool a $70 \%$. Os tecidos foram incluídos em parafina, cortados à espessura de 5 micrômetros, corados pela hematoxilina e eosina e observados em microscopia óptica (PROPHET, 1992), onde foi realizada a leitura das lâminas, avaliando-se a estrutura anatômica de cada órgão e suas respectivas alterações morfológicas. 


\subsection{Avaliação bacteriológica}

Nos órgãos que apresentaram evidências de inflamação de origem infecciosa, tais como presença de exsudatos, foram colhidas amostras do conteúdo através de "swabs" do material. As amostras foram semeadas em meio BHI (Brain Heart Infusion) e incubadas por 24 horas. Posteriormente, efetuou-se a leitura, anotando-se os aspectos de crescimento das colônias. A classificação foi realizada de acordo com as características morfológicas, morfotintoriais à técnica de Gram e provas bioquímicas seguindo-se metodologia recomendada por Carter (1988).

\subsection{Análise estatística}

Para comparar a frequência de fêmeas entre os grupos 1 e 2 , no tocante às alterações patológicas, foi utilizado o teste não paramétrico denominado qui-quadrado $\left(\mathrm{X}^{2}\right)$, ao nível de significância $\mathrm{p}=0,05$. $\mathrm{O}$ trabalho objetivou analisar principalmente os aspectos e descrição morfopatológica do sistema genital feminino de suínos. Desta forma, foi apresentado somente alguns valores percentuais em termos de ocorrência patológica dos indivíduos amostrados.

\section{RESULTADOS E DISCUSSÃO}

Do total de 169 fêmeas suínas analisadas foi observada patologia no genital de 37 (21,8\%) (Tabela 1). Foi observado que 27 fêmeas (73\%) do grupo 1 possuíam alterações patológicas, enquanto o grupo 2 representaram 10 fêmeas (27\%) com essas alterações. Esses valores percentuais foram estatisticamente significativos $\left(X^{2}=7,81 ; p=0,005\right.$ - Gráfico 1). 
Tabela 1 - Quantidade de animais gestantes e não gestantes, com e sem alterações

\begin{tabular}{cccc}
\hline & & Gestante & \multicolumn{2}{c}{ Não gestante TOTAL } \\
\hline Com alteração & 10 & 27 & 37 \\
\hline Sem alteração & 67 & 65 & 132 \\
\hline TOTAL & 77 & 98 & 169 \\
\hline
\end{tabular}

Fonte: Dados da pesquisa

Gráfico 1 - Valores percentuais dos grupos 1 e 2 com presença de alterações patológicas

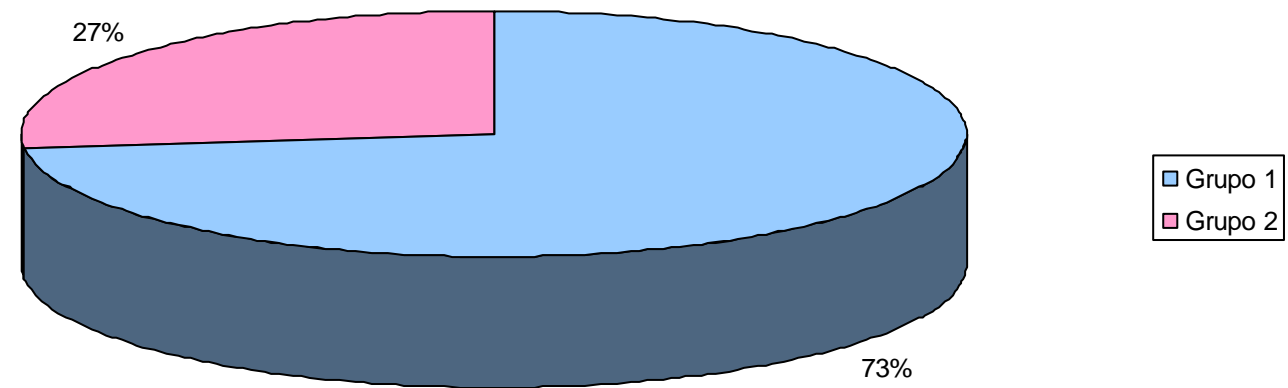

Fonte: Dados da pesquisa

Nos animais do grupo 1, os ovários apresentaram maior frequência de patologias 19 (44,1\%), enquanto que no grupo 2 o útero foi o órgão que apresentou maior frequência de patologias nove (20,9\%). A coexistência de mais de um processo patológico num mesmo órgão é o motivo de o número de diagnósticos atingirem o total de 21. 
Tabela 2 - Frequências dos diagnósticos morfopatológicos do sistema genital de fêmeas suínos abatidos em Mossoró, segundo o tipo de alteração, localização e frequência sobre um total de 169 animais

\begin{tabular}{|c|c|c|c|c|c|c|c|c|c|}
\hline Órgão & Alterações & Localiz & ação & Núr & & Freq & cia & & \\
\hline Ovário & Direito & Esquerd & & Bilat & & & & & \\
\hline & Ovário com hip & trofia & - & - & 1 & 1 & 4,8 & & \\
\hline & Cisto Folicular & 1 & 1 & 2 & 4 & 19 & & & \\
\hline & Cisto do corpo & iteo & 1 & 1 & - & 2 & 9,5 & & \\
\hline & Cisto de inclusã & germinal & - & 1 & - & 1 & 4,8 & & \\
\hline & Cisto luteínico & 1 & - & - & 1 & 4,8 & & & \\
\hline & Cisto paraováric & & & & & & & & \\
\hline & 2 & - & 10 & 47,6 & & & & & \\
\hline Tuba ute & Cisto d & parede $\mathrm{d}$ & a tuba & erina & 2 & 2 & - & 4 & 19 \\
\hline & Hidrossalpinge & 2 & - & - & 2 & 9,5 & & & \\
\hline & Piometra- & - & 4 & 4 & 19 & & & & \\
\hline & Endometrite foc & & - & 1 & 1 & 4,8 & & & \\
\hline & Hiperplasia end & metrial cí & stica & - & - & 1 & 1 & 4,8 & \\
\hline & Fetos macerado & - & - & 5 & 5 & 23,8 & & & \\
\hline & Fetos Mumifica & & - & - & 4 & 4 & 19 & & \\
\hline
\end{tabular}

Fonte: Dados da pesquisa

Nos ovários a patologia mais freqüente foi os cistos. Destes, os cistos paraováricos ocorreram em maior número, sendo oito $(38 \%)$ casos no grupo 1 e dois $(9,5 \%)$ no grupo 2 , seguido pelos cistos folicular com quatro $(19 \%)$ casos, cisto do corpo lúteo com dois $(9,5 \%)$ casos e cistos de inclusão germinal com um $(4,8 \%)$ caso. Concernente a localização dos cistos ovarianos, nota-se que a lesão ocorreu nos antímeros esquerdo e direito na mesma proporção. No ovário houve ainda presença de um (4,8\%) caso de hipotrofia ovariana.

Macroscopicamente, os cistos foliculares caracterizavam-se pela presença de uma formação cística variando de $2,5 \mathrm{~cm}$ a $6,0 \mathrm{~cm}$ de diâmetro, de parede delgada, contendo líquido claro e seroso. Em dois animais, nos antímeros direito e esquerdo havia formações cavitárias múltiplas (Figura 1). 
Figura 1 - Aspecto macroscópico do cisto folicular em fêmeas suínas

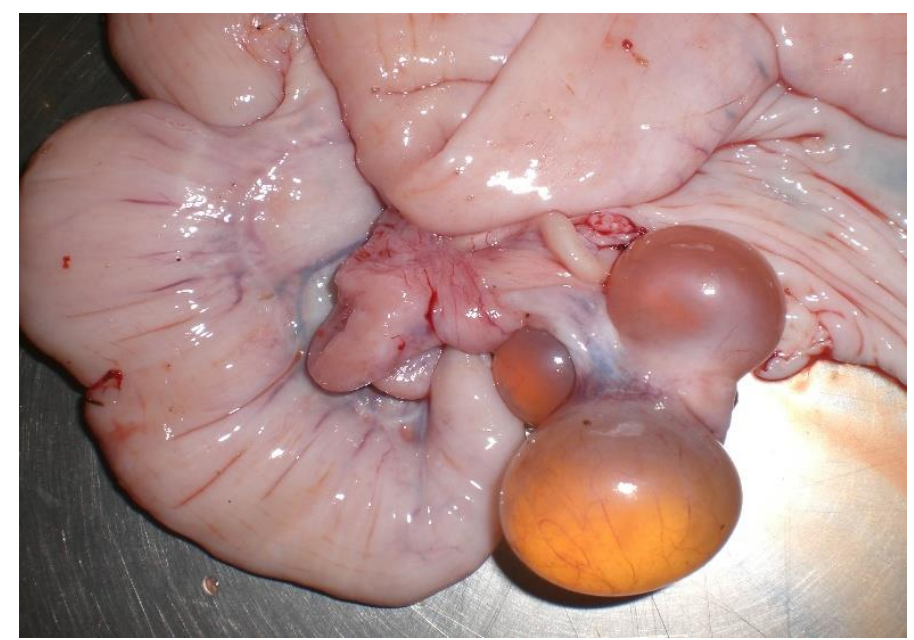

Fonte: Autores

Histologicamente observou-se a ausência de ovócito, zona pelúcida e células da granulosa, além da presença de epitélio estratificado com células cúbicas, envolto em tecido fibroso (Figura 2).

Figura 2 - Aspecto histológico do cisto folicular ovariano em fêmeas suínas. Hematoxilina eosina. 20X

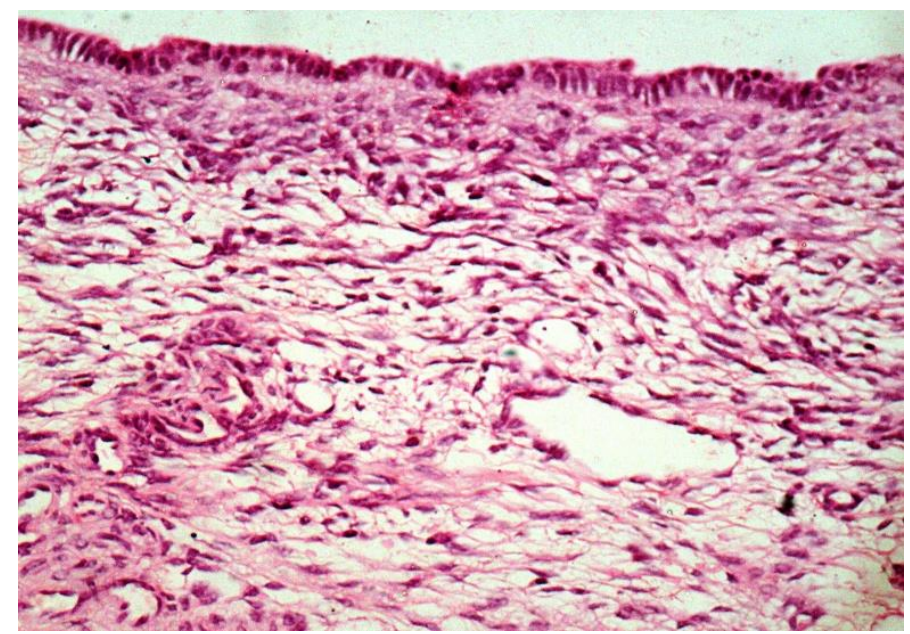

Fonte: Autores 
No estudo realizado por Moreira et al (2006), nas porcas podem estar presentes cistos individuais em conjunto ao corpo lúteo, encontrados em um ou ambos ovários. Podem ser cistos foliculares, luteínicos e hemorrágicos. Foi observado que das 25 fêmeas com cistos ovarianos, 17 (68\%) apresentavam ovários com cistos múltiplos e que apenas oito (32\%) destas possuíam cistos simples ou individuais em seus ovários.

Os achados macroscópicos e histológicos, observados no presente trabalho, se assemelham aos descritos por NASCIMENTO \& SANTOS (2003) e CARLTON \& McGAVIN (1998). A síndrome da degeneração cística ovariana tem-se mostrado uma das principais causas de descarte em fêmeas suínas com problemas reprodutivos. Em 64 leitoas que foram eliminadas por problemas de anestro, encontraram-se cistos ovarianos em 6,25\% dos animais (SILVEIRA et al., 1984). Nos genitais de 84 porcas, também descartadas por anestro, foram encontrados cistos ovarianos em 2,3\% dos animais (SILVEIRA, 1988). Porcas com cistos grandes e múltiplos podem estar em anestro intermitente ou permanente, conduzindo muitas vezes a um falso diagnóstico de gestação. Por outro lado, casos menos avançados podem não exibir manifestações e, neste caso, a fertilidade não seria prejudicada (WRATHALL, 1980).

Nesse estudo, o cisto de corpo lúteo foi diagnosticado em dois $(9,5 \%)$ casos no grupo 1. Macroscopicamente esse cisto caracterizou-se por apresentar uma cavidade cística central de aproximadamente de 2,0 cm (Figura 3). Em um animal o cisto ocorreu no lado direito e em outro no lado esquerdo.

Figura 3 - Aspecto macroscópico do cisto do corpo lúteo em fêmeas suínas

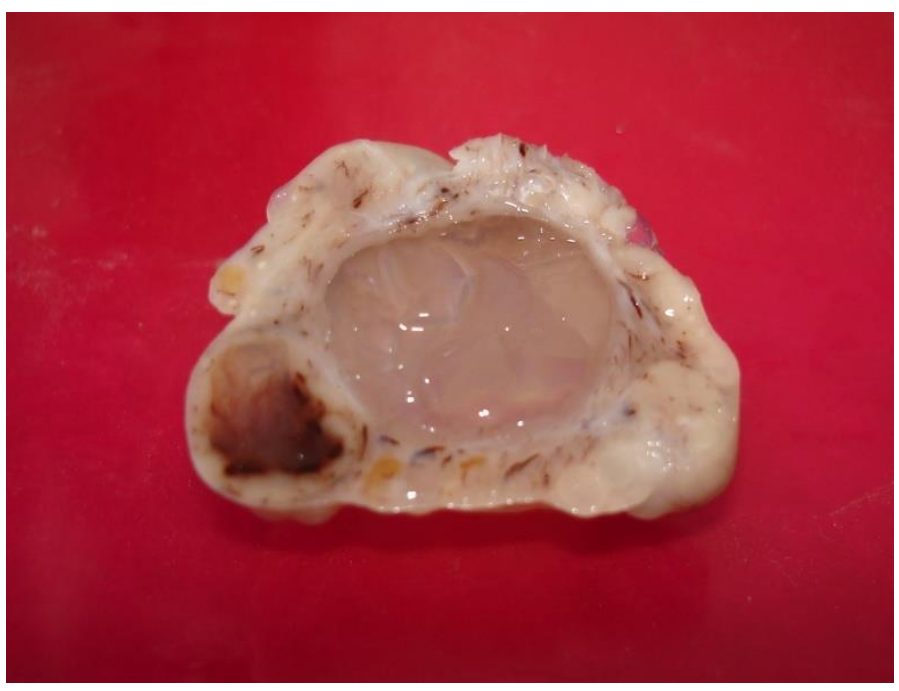

Fonte: Autores 
Microscopicamente, estes apresentaram células luteínicas próximas da cavidade cística alongadas, com núcleos picnóticos. Uma cápsula de tecido conjuntivo fibroso, de contorno irregular separava as células luteínicas da cavidade central (Figura 4).

Figura 4 - Aspecto histológico do cisto do corpo lúteo em fêmeas suínas. Hematoxilina eosina. 20X

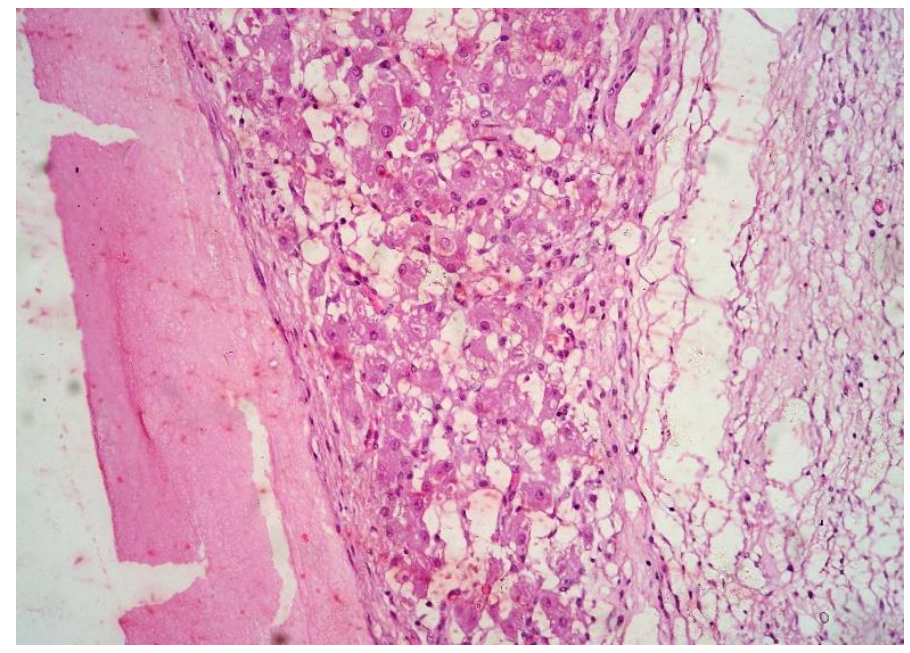

Fonte: Autores

O quadro histológico harmoniza com o que foi descrito por McEntee (1990) e Gavin (1980).

Há suspeitas de que cistos do corpo lúteo de grandes proporções possam comprometer a produção de progesterona pelo corpo lúteo e conseqüentemente diminuir as chances de estabelecimento da gestação (NASCIMENTO e SANTOS, 2003). O corpo lúteo cístico associa-se a excessiva maturação do folículo com degeneração da parede quando da ovulação (MILLER \& CAMPBEL, 1978).

Os cistos formados a partir do epitélio germinativo foram denominados de cistos de inclusão germinal, localizados no córtex ovariano. Foi identificado, durante o exame histopatológico, no ovário esquerdo de um $(4,8 \%)$ animal. Esses cistos iniciam no peritônio modificado e não no epitélio germinativo, e são limitados por uma única camada de células epiteliais cúbicas e achatadas (Figura 5). 
Figura 5 - Aspecto histológico do cisto de inclusão germinal em fêmeas suínas. Hematoxilina eosina. 20X

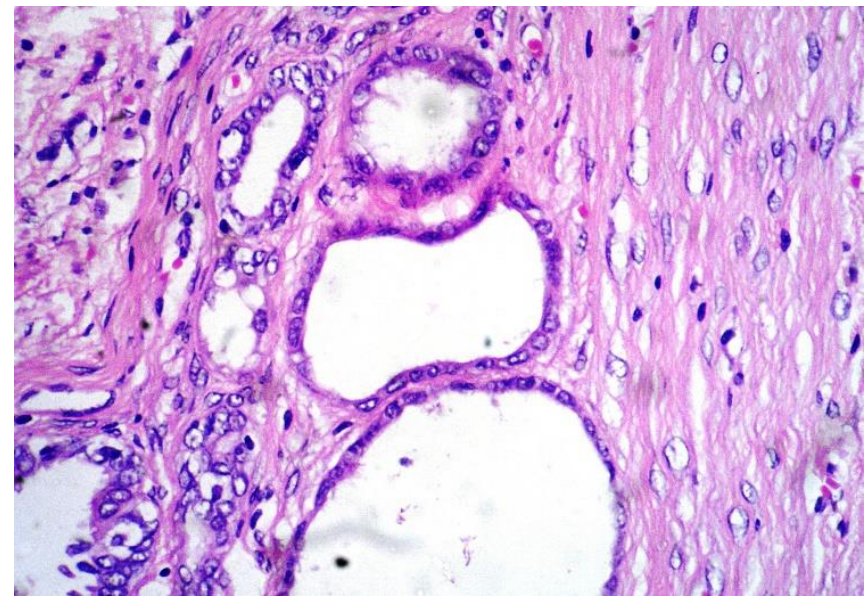

Fonte: Autores

$\mathrm{Na}$ maioria das espécies, os cistos de inclusão epitelial do ovário são pequenos e não tem significado clínico (JONES et al., 2000). Esse tipo de cisto ocorre em todas as espécies, sendo mais importante nas éguas, por interferirem na ovulação. As formações císticas destroem gradativamente o parênquima ovariano. Em outras espécies, apresentam dimensões muito reduzidas, sendo diagnosticado microscopicamente e carecendo de importância clínica. Os cistos de inclusão germinal não tem atividade de produção hormonal (NASCIMENTO \& SANTOS, 2003).

Adjacente aos ovários e tubas uterina, foram observados cistos paraováricos em oito (38\%) animais do grupo 1 e dois (9,5\%) animais do grupo 2, únicos ou múltiplos, de formatos variados (circulares, ovalados, alongados e multilobulados), localizado com maior frequência no lado direito (Figura 6). 
Figura 6 - Aspecto macroscópico do cisto paraovárico em fêmeas suínas

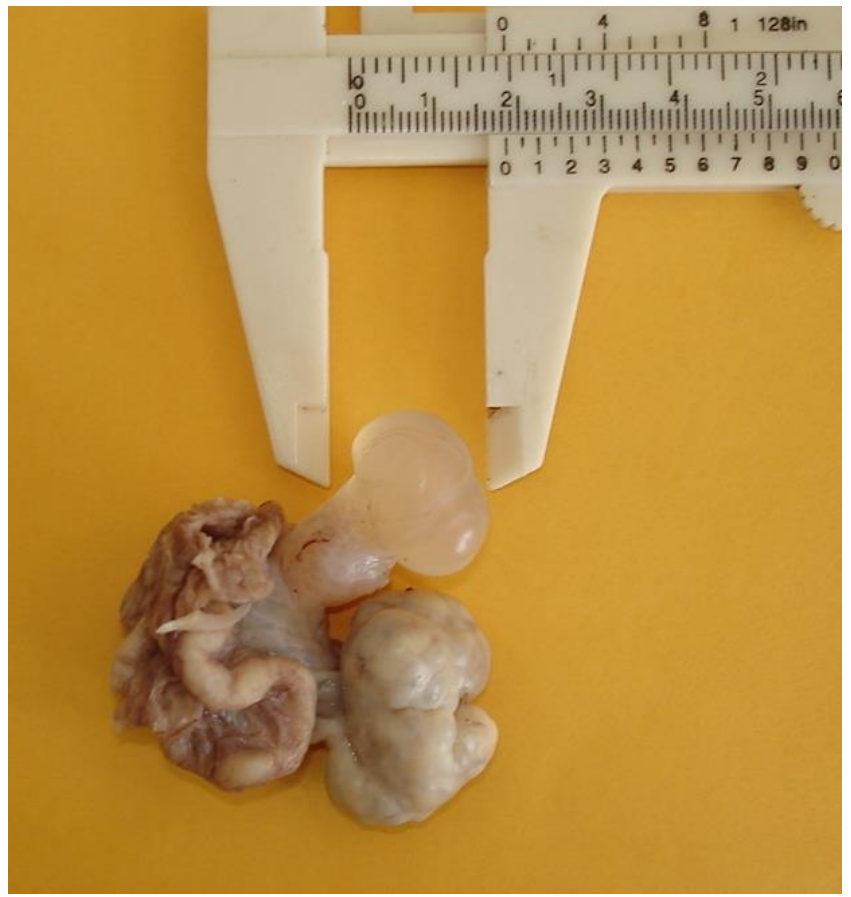

Fonte: Autores

Os cistos paraováricos eram revestidos por epitélio cúbico simples, envolvidos por finas camadas de fibras musculares lisa e tecido conjuntivo fibroso (Figura 7).

Figura 7 - Aspecto histológico do cisto paraovárico em fêmeas suínas. Hematoxilina eosina. $20 \mathrm{X}$

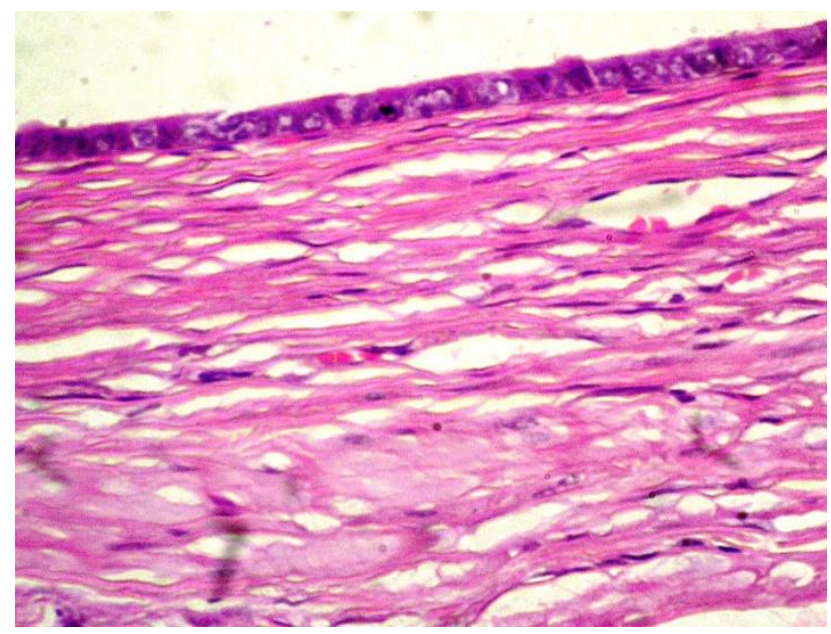

Fonte: Autores 
As alterações macroscópicas e histológicas, observados nos casos dos cistos ora descritos, coincide com as relatadas por McEntee (1990).

O termo cisto paraovárico é usado abrangetemente em referência a uma variedade de estruturas císticas, sem significados clínicos localizadas adjacentes ao ovário (MILLER \& CAMPBEL, 1978). Tais cistos ocorrem freqüentemente em muitas espécies e originam-se de remanescentes dos ductos mesonéfricos ou paramesonéfricos (McENTEE, 1990; JUBB et al., 1985).

Diagnosticou-se um $(4,8 \%)$ caso de hipoplasia ovariana bilateral em um animal do grupo 1. Macroscopicamente, os ovários hipoplásicos apresentaram-se reduzido de tamanho, consistência firme, alongado, com superfície lisa, com ausência de folículos ovarianos ou corpos lúteos (Figura 8).

Figura 8 - Aspecto macroscópico da hipoplasia ovariana em fêmeas suínas

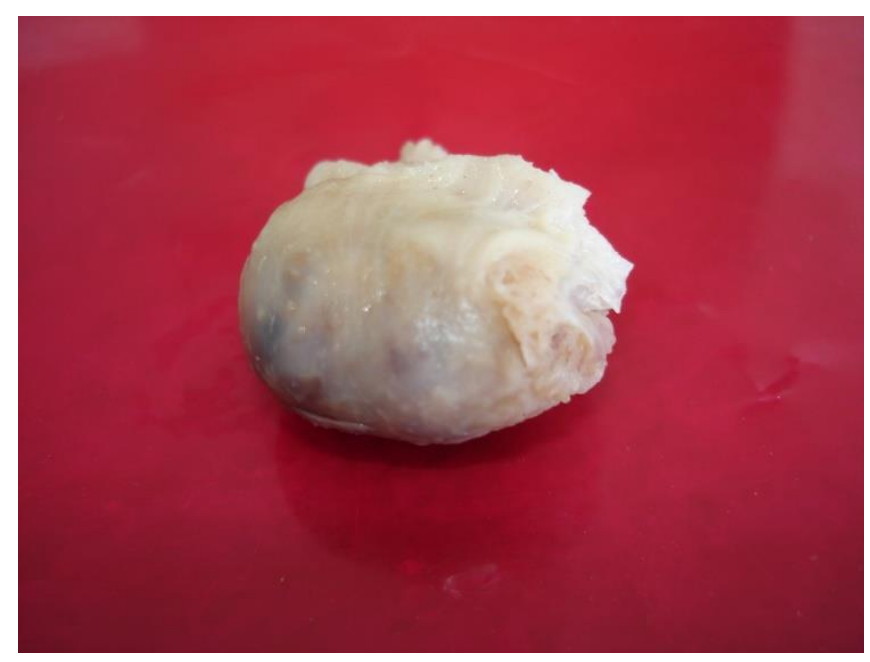

Fonte: Autores

No exame histológico os ovários hipoplásicos exibiam a cortical subdesenvolvida, com ausência de folículos e corpos lúteos; e a medular com aumento de tecido conjuntivo e vasos sanguíneos (Figura 9). Os achados anátomo-patológicos ajustam-se aos descritos por Batista (2006) em ovários de catetos criados em cativeiro no município de Mossoró. 
Figura 9 - Aspecto histológico da hipoplasia ovariana em fêmeas suínas. Hematoxilina eosina. 20X

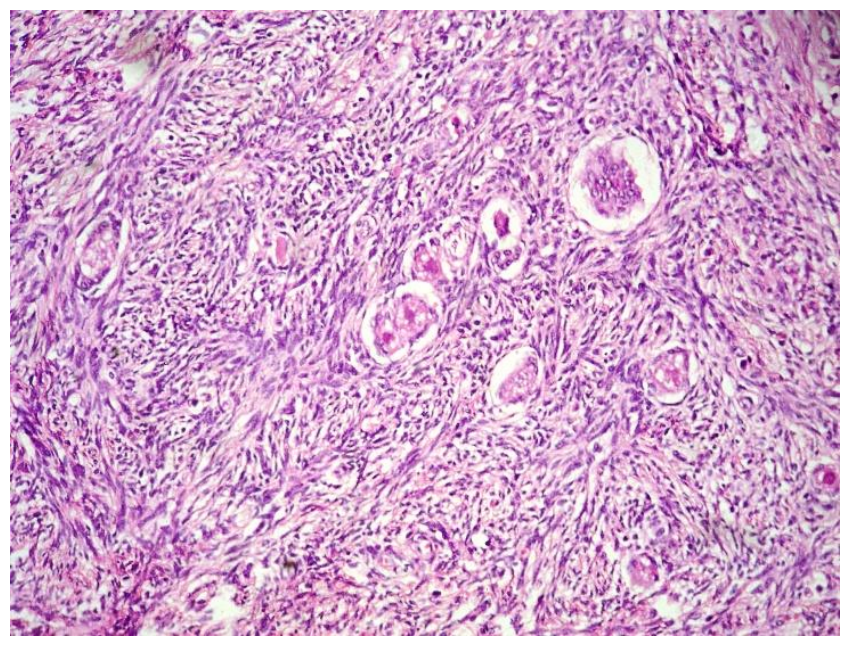

Fonte: Autores

A hipoplasia ovariana é uma alteração congênita descrita em várias espécies, sendo mais freqüente descrita em suínos e bovinos (McENTEE, 1990). Em bovinos, essa patologia tem como fator etiológico, um gene recessivo autossômico de penetrância incompleta (JONES et al., 2000). A hipoplasia ovariana bilateral resulta em esterilidade, sendo unilateral, o animal será subfértil, podendo transmitir tal característica aos descendentes, reduzindo a fertilidade do rebanho (NASCIMENTO \& SANTOS, 2003).

Com relação às tubas uterinas, foram encontradas quatro casos $(19 \%)$ de cistos de parede da tuba uterina e dois $(9,5 \%)$ casos de hidrossalpinge unilateral direita no grupo 1.

O cisto de parede da tuba uterina caracterizou-se de uma estrutura arredondada, na serosa, com diâmetro que variou entre 0,3 a $0,5 \mathrm{~cm}$, com presença de liquido claro em seu interior. Em alguns casos havia mais de um cisto por tuba (Figura 10). 
Figura 10 - Aspecto macroscópico do cisto da Tuba Uterina em fêmeas suínas

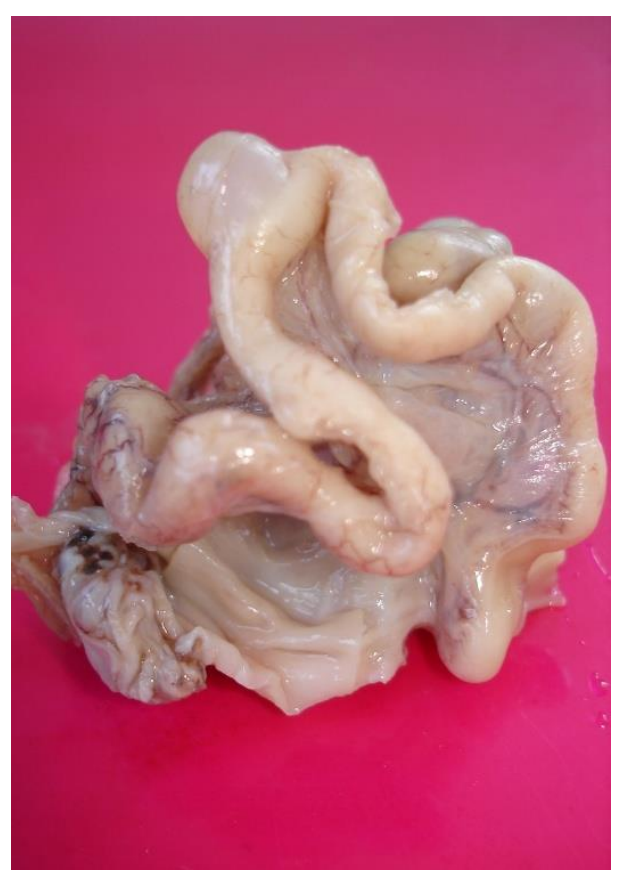

Fonte: Autores

$\mathrm{Na}$ histologia observou-se que este cisto se apresentou revestido por uma única camada de células cuboidais baixas (Figura 11). Os dados obtidos foram similares aos de Sant'Ana et al. (2004), o qual observou-se que os cistos de parede foram a patologia tubárica mais frequente.

Figura 11 - Aspecto histológico do cisto da tuba uterina em fêmeas suínas. Hematoxilina eosina. 20X

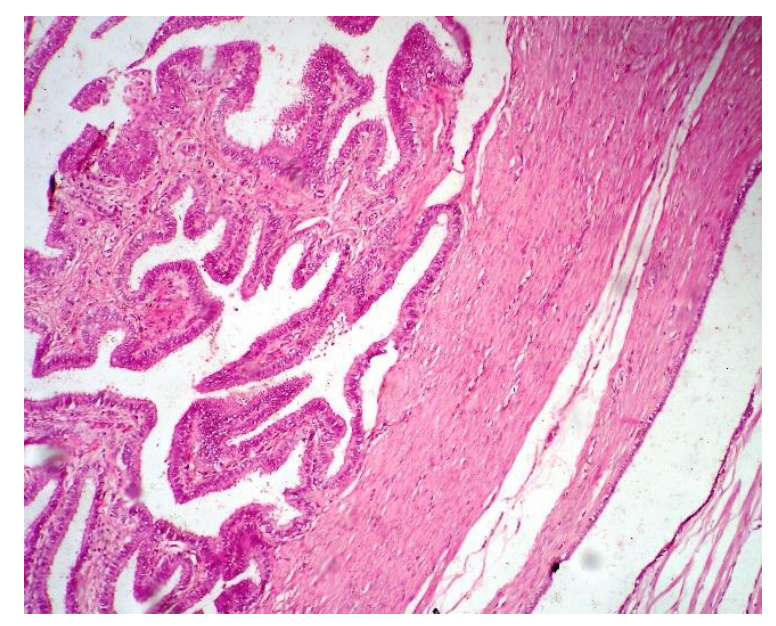

Fonte: Autores 
A macroscopia da hidrossalpinge caracterizou-se pela distensão da tuba uterina contendo em seu interior um líquido claro e flúido (Figura 12). Segundo Carlton \& Mcgavin (1998), a hidrossalpinge pode ter causas congênitas devido a aplasia segmentar da tuba uterina ou adquiridas sendo secundária a traumas ou inflamação crônica. Sant'Ana (2001) ao estudarem alterações macroscópicas e microscópicas da tuba uterina de matrizes suínas, verificaram que as patologias são freqüentes sendo importantes causas de subfertilidade e infertilidade na espécie.

Figura 12 - Aspecto macroscópico da hidrossalpinge em fêmeas suínas

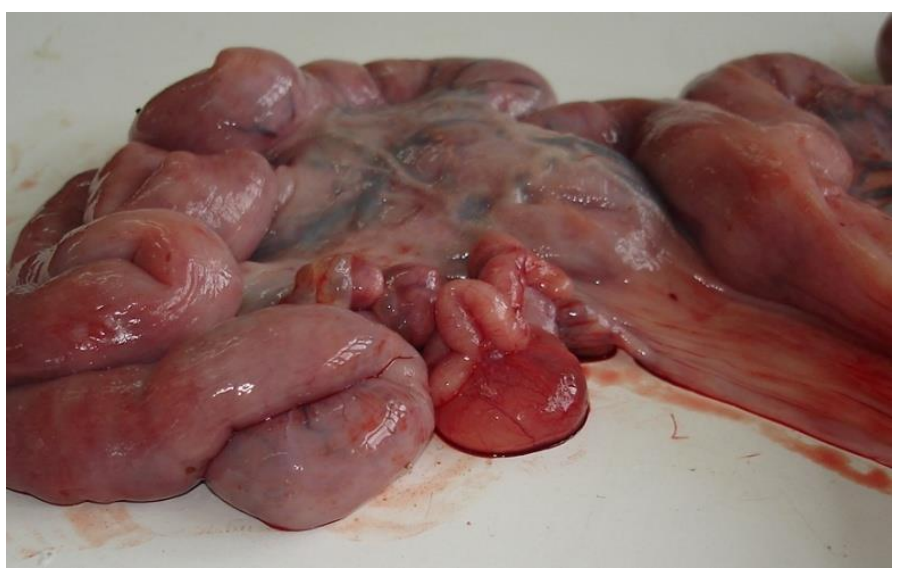

Fonte: Autores

As inflamações uterinas ocorreram em frequência elevada nos animais do grupo 1. Dentre os processos inflamatórios uterinos a piometra foi diagnosticada macroscopicamente e confirmada no exame histológico em quatro (19\%) animais pertencentes a este grupo. Nesses animais, ambos os cornos uterinos se apresentavam dilatados e preenchidos por exsudato purulento viscoso, mucosa hiperêmica, edemaciada e com extensos depósitos de fibrina amarelada (Figura 13). 
Figura 13 - Aspecto macroscópico do útero com piometra em fêmeas suínas

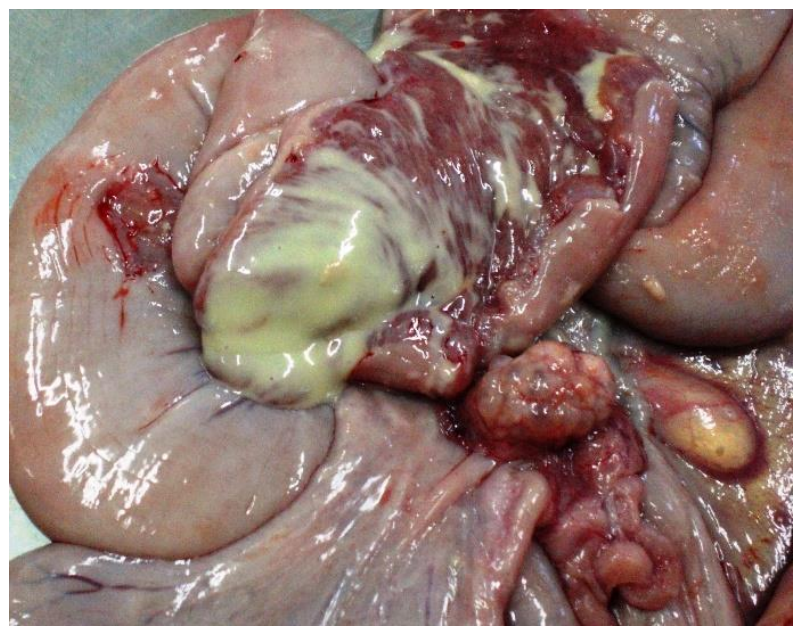

Fonte: Autores

$\mathrm{Na}$ histologia caracterizava-se por infiltrado inflamatório multifocal de polimorfonucleares neutrófilos no endométrio, presença de fibrina no interstício e no lúmen glandular (figura 14).

Figura 14 - Aspecto histológico da piometra em fêmeas suínas. Hematoxilina eosina. 20X

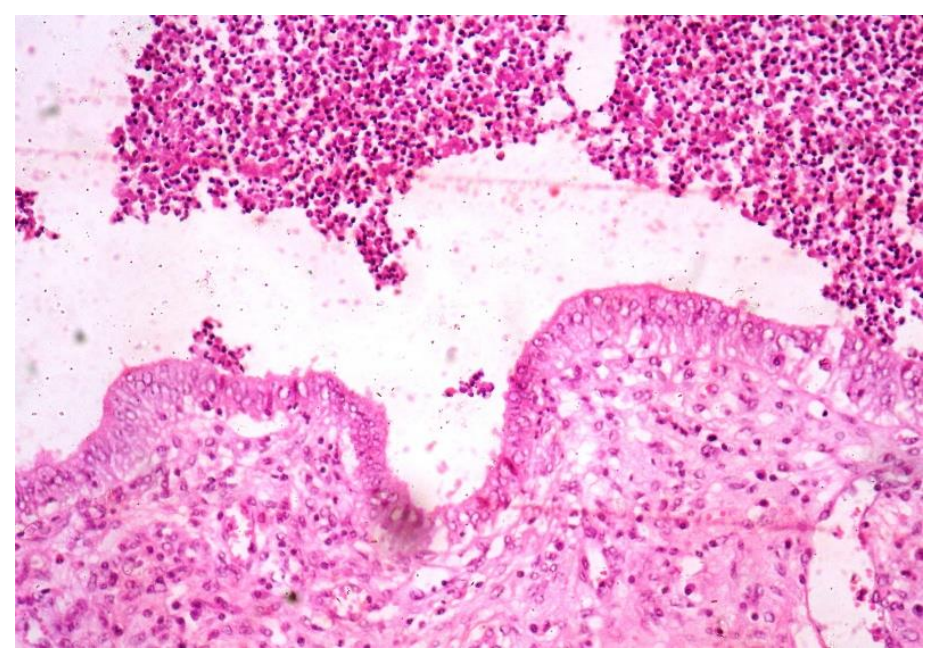

Fonte: Autores

O exame microbiológico realizado no muco coletado desses animais foi identificada a presença de Escherichia coli, Enterobacter aglomerans e Staphylococcus aureus.

$\mathrm{Na}$ porca, as alterações inflamatórias uterinas se alinham entre os principais fatores que atuam em detrimento da função reprodutiva, sendo responsáveis por repetição de cio, infertilidade temporária ou permanente e por perdas econômicas significativas, devido a 
aumento de dias não reprodutivos, descarte precoce das fêmeas, custos com medicamentos, complicações devidas a infecções geniturinárias, baixa produção de leite (hipogalaxia) que predispõe à diarréia nos leitões em amamentação. As bactérias mais freqüentemente isoladas do útero de porcas com descarga vaginal anormal são Escherichia coli, Staphylococccus spp. e Streptococcus spp. (NASCIMENTO e SANTOS, 2003).

Em um animal do referido grupo foi identificado durante o exame histopatológico um $(4,8 \%)$ caso de endometrite. A endometrite caracterizou-se, histologicamente, por infiltrado multifocal de células monucleadas no interstício e ao redor dos vasos (Figura 15).

Figura 15 - Aspecto histológico da endometrite em fêmeas suínas. Hematoxilina eosina. $20 \mathrm{X}$

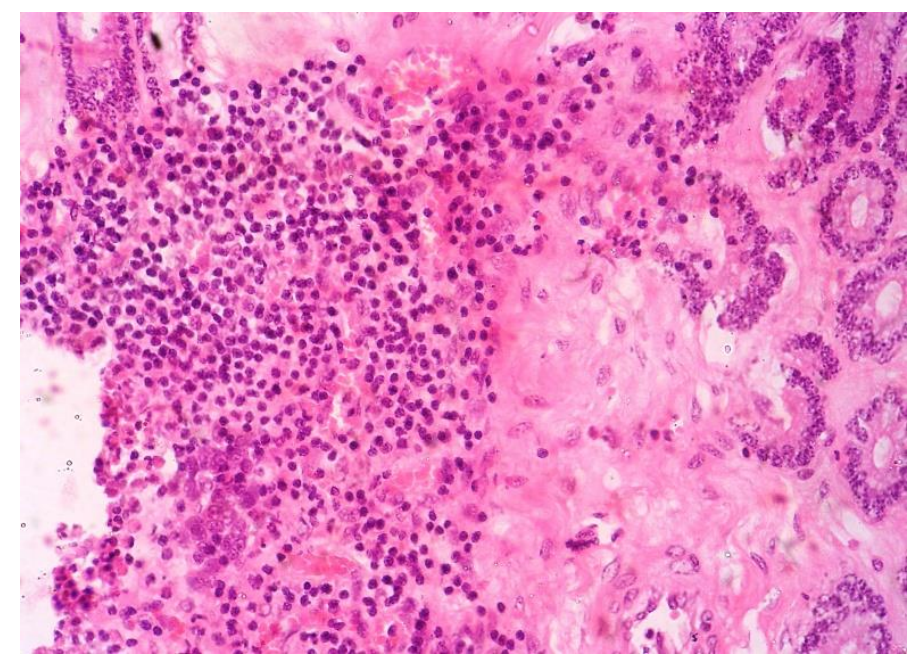

Fonte: Autores

A endometrite é um processo inflamatório mais freqüente no útero de diversas fêmeas domésticas, que interfere negativamente na eficiência reprodutiva dos rebanhos, aumentando a ocorrência de repetição de cio, os intervalos entre partos e diminuindo a produção de leite (NASCIMENTO e SANTOS, 2003).

No exame macroscópico e histológico, foi diagnosticado em um $(4,8 \%)$ animal a presença da hiperplasia endometrial cística. O endométrio desse animal apresentava-se com espessamento excessivo, congesto, com quantidade discreta de muco e múltiplas formações císticas translúcidas de pequenas dimensões (Figura 16). 
Figura 16 - Aspecto macroscópico da hiperplasia endometrial cística em fêmeas suínas

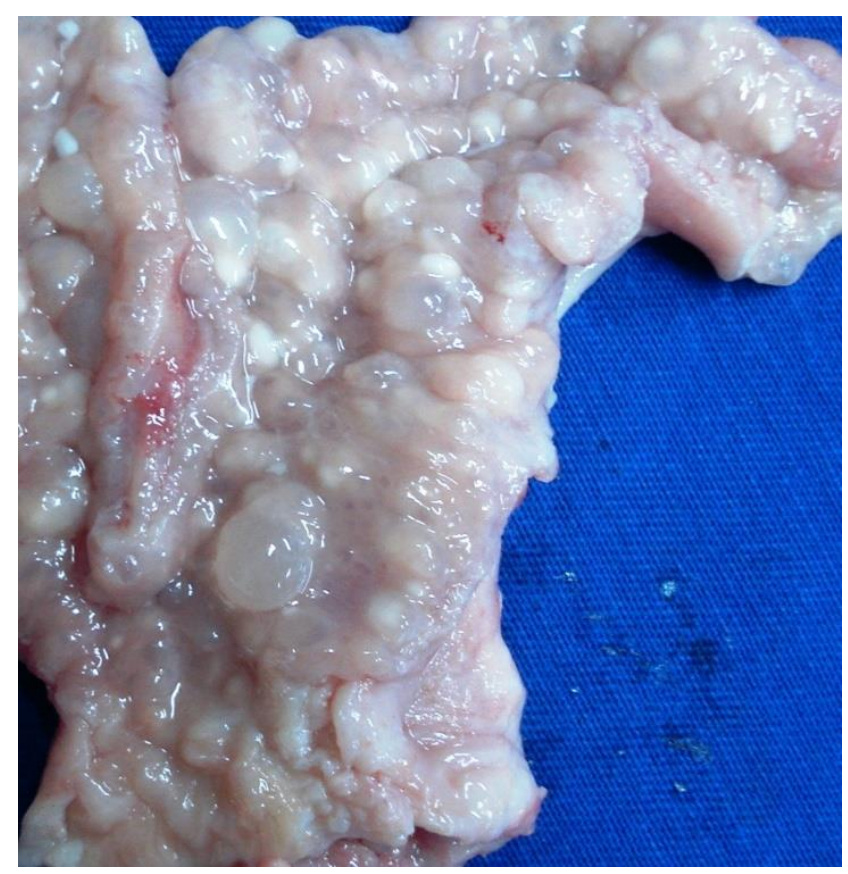

Fonte: Autores

No exame histológico observou-se grande número de glândulas endometriais dilatadas, cística com acúmulo de muco no lúmen (figura 17).

Figura 17 - Aspecto histológico da hiperplasia endometrial cística em fêmeas suínas. Hematoxilina eosina. 20X

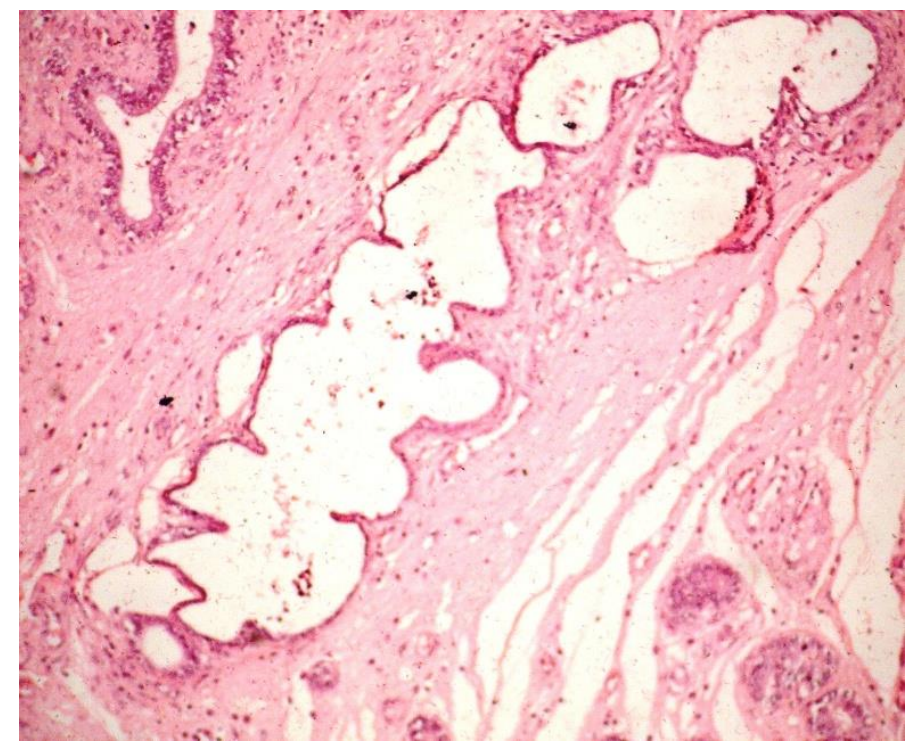

Fonte: Autores 
A hiperplasia endometrial cística tem sua etiologia nas alterações funcionais e lesões do sistema reprodutor de fêmeas acometidas por este "complexo de enfermidades" estão relacionadas aos distúrbios hormonais e associadas a infecção bacterianas. (GRUNERT, 2005). No grupo 2, as patologias mais freqüentes ocorreram no útero. Destas, a maceração fetal foi a patologia que atingiu maior prevalência, com cinco casos $(23,8 \%)$, seguido de quatro $(19 \%)$ casos de fetos mumificados. Os fetos macerados caracterizaram-se macroscopicamente por apresentarem estruturas ósseas liquefeitas, com exsudato escurecido e de odor fétido (Figura 18).

Figura 18 - Aspecto macroscópico da Maceração Fetal em fêmeas suínas

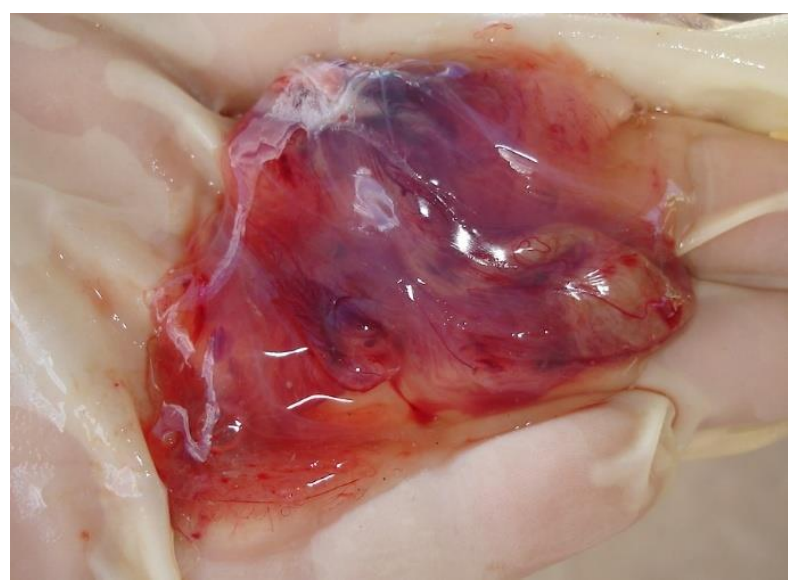

Fonte: Autores

Os fetos mumificados formavam uma massa escura e desidratada, com superfície de aspecto úmido, sem odor nem exsudação, além disso, havia apenas a cavidade ocular vazia (Figura 19).

Figura 19 - Aspecto macroscópico dos Fetos Mumificados em fêmeas suínas

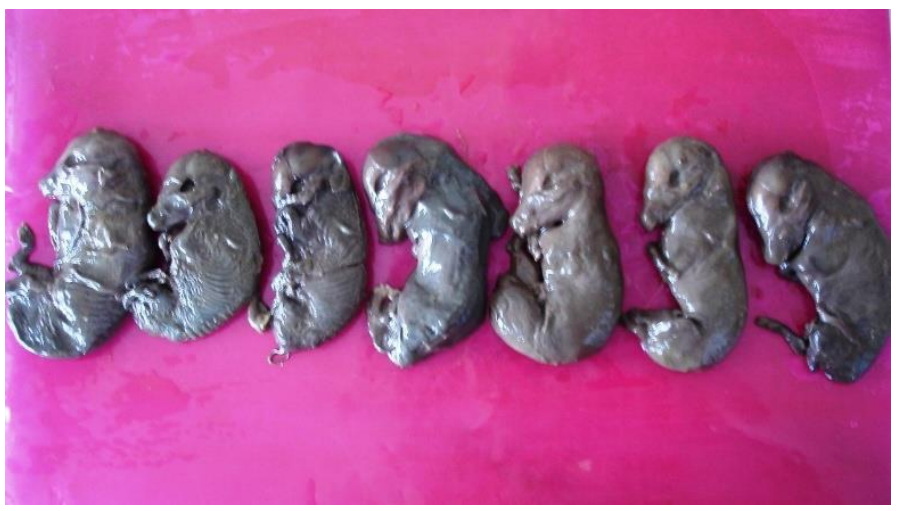

Fonte: Autores 
O feto macerado é aquele que sofreu destruição dos tecidos moles. Ao contrário da mumificação, a maceração ocorre na presença de contaminação bacteriana na cavidade uterina. A mumificação é mais freqüente em fêmeas multíparas, em especial nas porcas. $\mathrm{O}$ requisito básico para que haja mumificação é a ausência de contaminação bacteriana na cavidade uterina. Os líquidos fetais são reabsorvidos e as membranas fetais aderem-se ao feto morto desidratado (NASCIMENTO e SANTOS, 2003).

\section{CONCLUSÕES}

As patologias mais freqüentes, em escala decrescente que acometeram fêmeas suínas abatidas no município de Mossoró, foram no grupo 1: nos ovários os cistos ovarianos (Cistos paraováricos, cisto folicular, cisto do corpo lúteo e cisto de inclusão germinal) e a hipoplasia ovariana. Nas tubas uterinas ocorreu cisto de parede da tuba uterina e hidrossalpinge. No útero houve maior freqüência de piometra seguida de endometrite focal e hiperplasia endometrial. No grupo 2 houve maior frequência de fetos macerados seguido de fetos mumificados.

As lesões que acometeram o sistema genital de fêmeas suínas foram de natureza císticas (cistos ovarianos), inflamatória (piometra, endometrite), do desenvolvimento (hipoplasia ovariana), do crescimento celular (hiperplasia endometrial). Bem como patologias do útero gestante (feto macerado e mumificado).

\section{REFERÊNCIAS}

ACLAND, H. M. Sistema reprodutor feminino. In: THOMSON, R. G. Patologia veterinária especial. São Paulo: Manole , 1998. 736 p.

ALESSI, A. C. Patologia do sistema genital feminino. Disponível em $<$ www.url:www.sitedoboi.com.br $>$ Acessado em 06 fev.2002.

BANKS, W. J. Histologia Veterinária Aplicada. 2ed. São Paulo: Manole, 1991, p. 565-89.

BATISTA, J. S.; OLIVEIRA, A. F.; BARRETO, M. P. V. Patologias Do Sistema Genital Feminino De Catetos (Tayassu Tajacu) Criados Em Cativeiro. Revista Caatinga, Mossoró, v. 20, n. 2, p. 133-136, 2007.

BURROWS L. J, MEYN L. A, WEBER A. M. Maternal mor 
bidity associated with vaginal versus cesarean delivery. Obstetrics \& Gynecology, v. 103, n. 5, p. 907-912, 2004.

Carlton, W. W.; McGavin, M. D. Patologia Especial de Thomson. 2 ed. Porto Alegre: ArtMed, 1998.

CARTER, G. R. Enterobacteriaceae. In: CARTER, G. R.; CLAUS, G. W.; RIKIHISA, Y. Fundamentos da bacteriologia e micologia veterinária. São Paulo: Roca, 1988. cap. 17, $145-154 \mathrm{p}$.

D'ALLAIRE, S. Culling and mortality in breeding animals. In: STRAW, B. E. et al. Diseases of swine. 8th. Ames, Iowa: Iowa State University Press, 1999. p. 1003-1016.

DIAL G. D. et al. Systems approaches for improving the productivity of the breeding herd. In: University of Minesota. Proceedings of AD Leman Swine Conference. St. Paul, 1994, p. 84-93.

DUARTE, G. et al. Tratamento da endometrite puerperal com antibioticoterapia parenteral exclusiva. Revista Brasileira Ginecologia e Obstetetrícia, Rio de Janeiro, v. 27, n. 8, p. 456-60, 2005.

ENGBLOM, L. et al. Sow removal in Swedish commercial herds. Livestock Science. v, 106, n. 1, p. 76-86, 2007.

ETTINGER, S. J. Tratado de medicina interna veterinária. 3 ed. São Paulo: Manole, 1992.

FAUST, M.A.; ROBISON, O. W.; TESS, M. W. Genetic and economic analysis of sow replacement rates in the commercial tier of a hierarchical swine breeding structure. Journal of Animal Science, v. 71, n. 6, p. 1400-1406, 1993.

FIENI F. Patologia de los ovaries y el utero. In: WANKE, M. M.; GOBELLO, C. 2. ed. Reproducción en caninos y felinos domesticos. Buenos Aires: Inter-médica, 2006. p.7589.

FRENCH, L. M.; SMAILL, F. M. Antibiotic regimens for endometritis after delivery. Cochrane Database of Systematic Reviews, n. 1. 2002.

GAVIN, A. M. Patologia del ovario en la oveja. In: International congress on animal and artificial insemination, Madrid, v. 2., p. 177-91, 1980.

GLOSSOP, C. E. Infertility in the sow and gilt. Veterinary reproduction and obstretics. In: ARTHUR, G. H. et al. Veterinary reproduction \& obstetrics. 7. ed. London: WB Saunders. London, 1996. p 468-496.

GRUNERT, E; BIRGEL, E. H; VALE, W. G. Patologia e clínica da reprodução dos animais mamíferos domésticos. São Paulo: Livraria Varela, 2005. 551 p.

GUETTY, R. Anatomia dos animais domésticos. 5. ed. Rio de Janeiro: Interamericana, 1981. 
HAFEZ, E. S. E. Reprodução animal. 6. ed. São Paulo: Manole, 1995. p. 95-125.

HAFEZ, E. S. E.; HAFEZ, B. Reprodução Animal. $7^{a}$ ed. São Paulo: Manole, 2004. 513 p.

JONES, T. C; HUNT, R. D; KING, N. W. Patologia Veterinária. 6a Ed. São Paulo: Manole, 2000. 1415 p.

JUBB, K. V. F; KENNEDY, P. C.; PALMER, N. Pathology of domestic animals. San Diego: Academic Press, 2012.

KING V. L.; XUE J. L. Database benchmarking summaries for breeding herds. In: PIGCHAMP ${ }^{\circ}$. Improving herd production in 55 countries around the world. Annual report 1996. Minesota: University of Minesota, 1996. p. 3-21.

MADEC, F.; JOSSE, J. Utilization des methodes d'analyse des donnes pour l'etude de maladies d'elevage application du porc. Epid. Sante Anim, v.6, p.35-63, 1984.

McENTEE, M. Reproductive pathology of the domestics mammals. San Diego: Elsevier, 1990.

MILLER, R. I; CAMPBELL, R. S. F. anatomy and pathology of the bovine ovary and oviduct. Veterinary Bulletin. v. 48, n. 9, p. 737-53, 1978.

MOREIRA, F. et al. Aspectos macroscópicos dos ovários de matrizes suínas, oriundas de granjas da microrregião de Rio Verde-Go e descartadas para abate por motivos diversos. Archives of Veterinary Science, v.11, n.3, p.47-52, 2006.

MUIRHEAD, M. R. Epidemiology and control of vaginal discharges in the sow after service. The Veterinary Record, v.119, n. 10, p.233-235, 1986.

MURDOCH, W. J. Ovarian surface epithelium, ovulation and carcinogenesis. Biological Reviews of the Cambridge Philosophical Society, v.71, n.4, p.529-543, 1996.

NASCIMENTO, E. F. do; SANTOS, R. L. Patologia da Reprodução dos Animais Domésticos. Rio de Janeiro: Guanabara Koogan. 2003.

NOGUEIRA FILHO, S. L. G.; NOGUEIRA, S. S. C.; SATO, T. A Estrutura Social de Pecaris (Mammalia, Tayassuidae) em Cativeiro. Revista de Etologia. São Paulo, v. 1, n. 2, p. 89-98, 1999.

NUNEZ, Q. M. Morfologia del tracto genital de los pequeños ruminantes. Revista Científica, Luz, v. 3, n. 2, p.77-86, 1993.

OKTAY, K.; BRIGGS, D.; GOSDEN, R. G. Ontogeny of follicle-stimulating hormone receptor gene expression in isolated human ovarian follicles. The Journal of Clinical Endocrinology \& Metabolism, v. 82, n. 11, p.3748-51, 1997.

OLIVEIRA, K. S. Complexo hiperplasia endometrial cística. Acta Scientiae Veterinariae, Porto Alegre, v. 35, n. 2, p. 270-272, 2007. 
PINEDA, M. H. Female reproductive system. In: MCDONALD, L.E. Veterinary endocrinology and reproduction. 4. ed. Philadelphia: Lea \&Febiger, 1989.

PINHEIRO, M. J. P.; SILVA, F. N.; AZEVÊDO, C. M. S. B. Avaliação de parâmetros reprodutivos em catetos (Tayassu tajacu) criados em cativeiro. Revista Caatinga, Mossoró, v.14, n. 1-2, p. 71-74, dez. 2001.

PROPHET, E. B. et al. Afip laboratory methods in histotechnology. Washington: American Registry of Pathology, 1992. 278 p.

RODRIGUEZ-ZAS, S. L. et al. Bioeconomic evaluation of sow longevity and profitability. Journal of Animal Science, v. 81, n. 12, p. 2915-2922, 2003.

ROSA, N. A.; REAL, C. M. Desmame interrompido, novo método para aumentar a fertilidade do rebanho bovino. Arquivo da Faculdade de Veterinária da UFRGS, v. 6, p. 63, 1978

SALISBURY, G. Fisiologia de la reproducctión e Inseminación Artificial de los bovidos. Zaragoza: Editora Acribia, 1982.

SANT'ANA, F. J. F. Histologia e histoquímica das tubas uterinas de porcas (matrizes) abatidas em matadouros. 2001. Dissertação (Mestrado em Medicina Veterinária) Universidade Federal de Minas Gerais, Belo Horizonte, 2001.

SANT'ANA, F. J. F.; NASCIMENTO, E.F.; NOGUEIRA, J.C.; SERAKIDES, R. Atividade secretória de tubas uterinas com e sem patologia de porcas adultas nas fases folicular e luteínica. Arquivo Brasileiro de Medicina Veterinária e Zootecnia, v. 56, n. 1, p.36-45, 2004.

SAUMANDE, J. Ovogenèse et folliculogenèse. Rec. Méd. Vét., v. 157, p.29-38. 1981.

SEHESTED E. Economy of sow longevity. In: Nordiska Jordbruksforskares Förening Seminar. Longevity of sows. Proceedings. Tjele, Denmark. 1996. p. 101-108.

SILVEIRA, P. R. S. O problema do anestro na fêmea suína. In: Anais do CONGRESSO BRASILEIRO DE REPRODUÇÃO ANIMAL, Campinas, Cargil, 1988. p.188-201.

SILVEIRA, P. R. S.; BARROS, S. S.; WENTS, I. Observações macroscópicas e histológicas do trato genital de leitoas descartadas por anestro. Pesquisa Agropecuária Brasileira, Brasília, v.19, n.9, p.1169-73, 1984.

SMITH, P.W.S-O. et al. Ontogeny of ovarian follicle development in Booroola sheep fetuse that are homozogous carriers or non-carriers of the FecB gene. J. Reprod. Fert. v. 100, n. 2, p.41-54, 1994.

SOBESTIANSKY, J. et al. Clinica e patologia suína. 2ed. Goiânia: J. Sobestiansky, 1999, p. 92-289. 
STALDER K.J. et al. Financial impact of average parity of culled females in a breed-to-wean swine operation using replacement gilt net present value analysis. Journal of Swine Health and Production, v. 11, n. 2, p. 69-74, 2003.

TONIOllo, G. H.; VICENTE, W. R. R. Patologias da Gestação In: Manual de Obstetrícia Veterinária. 2. ed. São Paulo: Editora Varela, pp. 43-64, 2003.

TSUMURA, I. et al. Cyst formation in mesosalpinx, mesovarium and fimbria in cows and sows. Jpn. The Japanese Journal of Veterinary Science, v. 44, n. 1, p. 1-8, 1982.

TUMMARUK, P. et al. Repeat breeding and subsequent reproduvtive performance in Swedish Landrace end Swedish Yorkshire sows. Animal reproduction science. v.67, n. 3, p. 267-280, 2001.

VARGAS, A.J.; WENTZ, I.; BORTOLOZZO, F. Desempenho de fêmeas suínas após apresentarem falhas reprodutivas. In: V Seminário Internacional de Aves e Suínos - Ave Sui, Anais. Florianópolis-SC, p. 256-63, 2005.

WENTZ, I. et al. A hipertermia durante o estro pode afetar o desempenho reprodutivo de fêmeas suínas. Ciência Rural, Santa Maria, v. 31, n. 4, p. 651-656, 2001.

WILLIAMS, C. L.; STANCEL, G. M. Estrogênioe progestogênios In: GOODMAN, L. S. As bases farmacológicas da terapêutica, 9.ed. Rio de Janeiro: McGraw-Hill, 1996, p. 1046-1065.

WRATHALL, A. E. Ovarian disorders in the sow. Veterinary Bulletin, v. 50, n. 4, p. $253-$ $71,1980$. 


\section{TERATOMA MALIGNO OVARIANO EM ÉGUA: ESTUDO DE CASO}

\section{Julliano Pimentel Siqueira}

Faculdade Terra Nordeste, FATENE, Caucaia, CE

Lattes: http://lattes.cnpq.br/2102910504730062

\section{Paula Bittencourt Vago}

Faculdade Terra Nordeste, FATENE, Caucaia, CE Lattes: http://lattes.cnpq.br/2140592626597725 ORCID: https://orcid.org/0000-0003-3563-3812

\section{Michelle Costa e Silva}

Faculdade Terra Nordeste, FATENE, Caucaia, CE Lattes: http://lattes.cnpq.br/2140592626597725 ORCID: https://orcid.org/0000-0003-3563-3812

Informações sobre o artigo:

\section{Recebido em:}

19/04/2021

Aceito em:

$23 / 04 / 2021$

Data de publicação:

$19 / 07 / 2021$

Palavras-chave:

Égua

Ovário

Teratoma

Tumor

\section{RESUMO}

O teratoma é um tumor derivado de células germinativas ovarianas primitivas totipotentes e que exibe diferenciação celular em diversos tecidos, sendo uma condição rara em equinos e em sua maioria considerados benignos. O objetivo deste trabalho é relatar caso raro de teratoma maligno em égua com infertilidade, com ênfase no diagnóstico clínico, ultrassonográfico, hormonal e histopatológico e no tratamento cirúrgico realizado. Uma fêmea equina mestiça de quarto de milha, multípara, 19 anos de idade, pertencente ao plantel da Cavalaria da Policia Militar do Estado do Ceará foi atendida e acompanhada desde o dia 12 de abril de 2018, apresentando infertilidade e sendo submetida a várias coberturas por monta natural e inseminações sem sucesso de fertilização. Foi realizado exame ginecológico geral da égua observando-se hipertrofia ovariana. Estabeleceu-se como conduta inicial o acompanhamento sequencial por palpações transretais, exames ultrassonográficos, além da realização de citologia e cultura uterina, optando-se pela remoção cirúrgica do ovário esquerdo diante do diagnóstico presuntivo de tumor ovariano. O procedimento e a evolução do caso foram satisfatórios e o animal recebeu alta após a retirada dos pontos de pele em 15 dias. O diagnóstico final foi estabelecido após exame histopatológico, resultado em quadro compatível raro de teratoma maligno. O teratoma ovariano é uma patologia rara em égua, que causa infertilidade, devendo ser diferenciado de outras patologias que afetam os ovários. A avaliação da história reprodutiva completa da fêmea e a realização de uma série de exames transretais e ultrassonográficos durante um certo período de tempo são necessários para estabelecer um diagnóstico clínico presuntivo. No entanto, para o diagnóstico final, o exame histopatológico do tecido ovariano é essencial para verificação de condição rara de malignidade do teratoma. 


\section{OVARIAN MALIGNANT TERATOMA IN MARE: CASE STUDY}

\section{ABSTRACT}

Teratoma is a tumor derived from totipotent primitive ovarian germ cells and exhibits cell differentiation in several tissues, being a rare condition in equines and most of them considered benign. The objective of this study is to report a rare case of malignant teratoma in mare with infertility, with emphasis on clinical, ultrasonographic, hormonal and histopathological diagnosis and surgical treatment. A quarter-mile, multiparous, female, 19-yearold female crossbred female from the Military Police Cavalry of the State of Ceará was attended and monitored since April 12, 2018, presenting infertility and being submitted to several natural mating and inseminations without successful fertilization. A general gynecological examination of the mare was performed, observing ovarian hypertrophy. Transrectal palpitations, ultrasound examinations, and cytology and uterine culture were established as the initial course, and the surgical removal of the left ovary was carried out in the face of the presumptive diagnosis of ovarian tumor. The procedure and the evolution of the case were satisfactory and the animal was discharged after removal of the skin spots in 15 days. The final diagnosis was established after histopathological examination, resulting in a rare compatible picture of malignant teratoma. Ovarian teratoma is a rare pathology in mare, which causes infertility, and must be differentiated from other pathologies that affect the ovaries. The evaluation of the female's complete reproductive history and the performance of a series of transrectal and ultrasound examinations over a certain period of time are necessary to establish a presumptive clinical diagnosis. However, for the final diagnosis, histopathological examination of the ovarian tissue is essential to check for a rare condition of teratoma malignancy.

\section{INTRODUÇÃO}

Patologias que geram hipertrofia ovariana são comuns em éguas (WESTERMANN et al., 2003) e podem ser de origem neoplásica ou não neoplásica (NIE e MOMONT, 1992). Dentre os distúrbios neoplásicos, os tumores ovarianos que acometem as fêmeas equinas são: tumor de células da granulosa (TCG), tumor de células da teca (tecoma), tumores mesenquimatosos (hemangioma, linfoma, fibroma e leimioma) e tumores de células germinativas (disgermioma e teratomas) (HARLAND, 2009).

Teratomas são derivados de células germinativas ovarianas primitivas totipotentes que podem se diferenciar em vários tecidos derivados das três camadas germinativas embrionárias (ectoderme, endoderme e mesoderme) (VICUS et al., 2011), podendo conter pelos, ossos, músculos e outros tecidos, sendo em sua maioria considerados benignos 
(MCKINNON et al., 2011). Contudo, alguns dos tecidos que compõem um teratoma podem tornar-se malignos (OUTWATER, 2001), dando origem a adenocarcinomas (VAN CAMP et al., 1989) ou a teratocarcinomas em éguas (FRAZER et al., 1988).

A teoria mais aceita para a etiologia dos teratomas ovarianos envolve a ativação antigênica de oócitos (OLIVEIRA et al., 2004). Para fins de diagnóstico dos teratomas, convém identificar o histórico do animal, realizar a palpação transretal, avaliar os achados ultrassonográficos, laboratoriais e histopatológicos (HARLAND, 2009), sendo que o tratamento de escolha consiste na remoção cirúrgica denominada ovariectomia (MCKINNON et al., 2011).

Ressalta-se que embora não sejam, comumente, considerados tumores funcionais, os teratomas podem estar associados à interrupção da ciclicidade nas éguas (OLIVEIRA et al., 2004), sendo a remoção do ovário afetado útil para a restauração da fertilidade do animal (MCKINNON et al., 2011). Relatos de teratomas malignos em éguas são raros.

Diante desse contexto, este trabalho teve como objetivo relatar caso raro de teratoma maligno em égua com infertilidade, com ênfase nas alterações clinicas, ultrassonográficas e laboratoriais, assim como e no tratamento cirúrgico realizado.

\section{RELATO DE CASO}

Uma égua mestiça de quarto de milha, multípara, 19 anos de idade, pesando aproximadamente $400 \mathrm{~kg}$, escore corporal 7, pertencente ao plantel da Cavalaria da Policia Militar do Estado do Ceará, foi atendida no dia 12 de abril de 2018 no referido local. A fêmea era regularmente vacinada e vermifugada, possuía a alimentação à base de concentrado balanceado para éguas em atividade reprodutiva e volumoso à base de feno de Tifton e apresentava os parâmetros vitais do exame físico dentro da normalidade.

De acordo com a anamnese, a última parição ocorreu no ano de 2015 e desde então foram realizadas sucessivas coberturas por monta natural sem êxito reprodutivo.No exame ginecológico, foi avaliada a conformação da vulva e clitóris, estando ambos em condições anatômicas normais para a espécie com mucosas normocoradas. Com o auxílio de um espéculo vaginal do tipo Polansky foram inspecionadas a vagina e a cérvix, ambas sem alterações macroscópicas ao exame.

$\mathrm{Na}$ palpação do trato reprodutivo por via transretal, não foi perceptível qualquer alteração no útero, porém o exame revelou aumento significativo no tamanho do ovário 
esquerdo (OE), apresentando consistência firme e superfície irregular com uma protuberância pontiaguda e sólida. Seu formato era arredondado, não sendo possível identificar a curvatura maior ou menor, nem a região da fossa ovulatória. Já o ovário direito (OD) apresentou-se normal em tamanho, formato e consistência.

$\mathrm{Na}$ avaliação ultrassonográfica realizada com um aparelho Mindray DP-10, com um transdutor linear numa frequência de $5 \mathrm{MHZ}$, foi detectado edema uterino de grau 1 numa escala de 1 a 5, como também a presença de cistos no corpo, na bifurcação do útero e nos terços proximais dos cornos uterinos direito e esquerdo (Figura 1). O OD encontrava-se polifolicular, com 2 folículos maiores, ambos medindo $17 \mathrm{~mm}$. Já no OE, apresentava estruturas saculares anecóicas, com formato irregular, a maior medindo $27 \mathrm{~mm}$, que a princípio foi descrito como um folículo. Já na região centro-lateral do OE encontramos uma grande e extensa estrutura hiperecóica, que a princípio foi identificada como um corpo lúteo (CL) de grande extensão, ocupando quase a totalidade do restante do estroma ovariano.

Figura 1 - Cistos no corpo na bifurcação do útero e nos terços proximais dos cornos uterinos direito e esquerdo

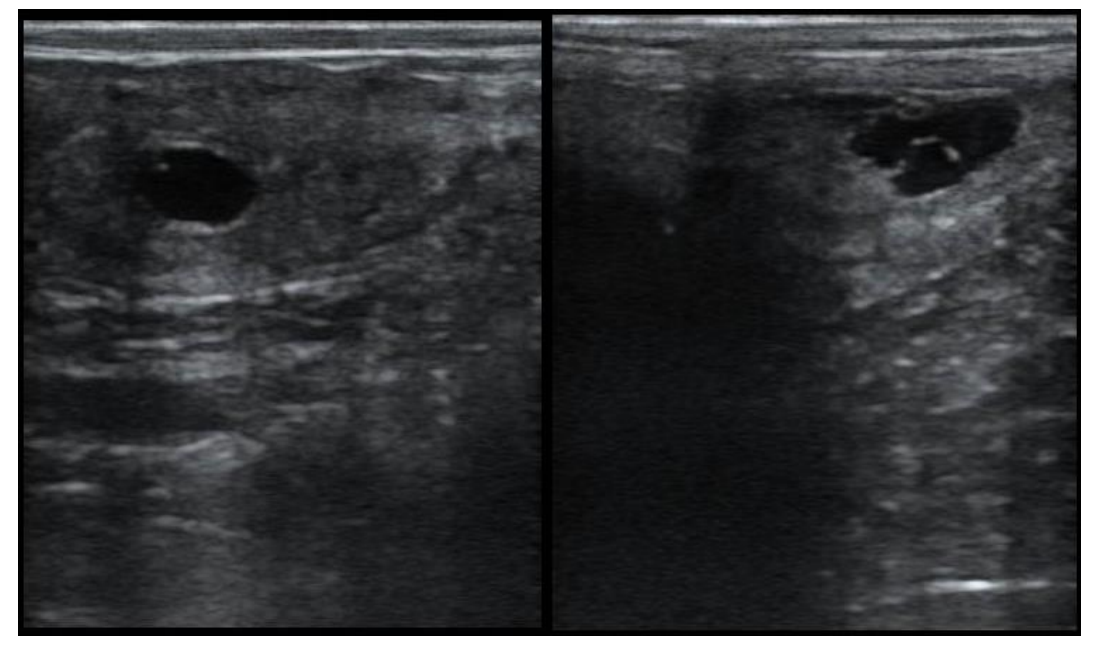

Fonte: Autores

Estabeleceu-se como conduta inicial o acompanhamento sequencial por palpações transretais e exames ultrassonográficos, revelando ciclos estrais irregulares. No OE verificouse a permanência da hipertrofia ovariana. As estruturas saculares não haviam evoluído ou regredido, como também nenhuma mudança evidente na massa hiperecóica ocorreu, tendo sido visualizado apenas o desenvolvimento de folículos hemorrágicos, um deles medindo 56 mm (Figura 2). Já no OD, constatou-se o desenvolvimento e a atresia folicular normalmente. 
$\mathrm{Na}$ avaliação clínica da fêmea foi observado distúrbio comportamental com libido exacerbada, incompatível com a fase do ciclo estral, além de infertilidade após sucessivas coberturas por monta natural. Foi realizada hormonioterapia para induzir ovulação com Gonadotrofina Coriônica Humana (HCG) (Chorulon®) na dose de 3000 U.I, por via endovenosa, como também Desorelina (Sincrorrelin ${ }^{\circledR}$ ) na dose de $750 \mu \mathrm{g}$, por via intramuscular, e para lisar corpo lúteo, Prostaglandina sintética (Ciosin $\left.{ }^{\circledR}\right)$ na dose de 0,265 mg por via intramuscular.

Figura 2 - Ovário Esquerdo. Cistos ovarianos acompanhados através de ultrassonografia por 8 meses $(\mathrm{a}, \mathrm{b})$ (setas azuis). Um dos folículos hemorrágicos presentes no ovário esquerdo, medindo $56 \mathrm{~mm}$ (c,d). Corpo Lúteo observado no ovário esquerdo após a realização da terapia hormonal para tratar os folículos hemorrágicos (e) (seta azul)

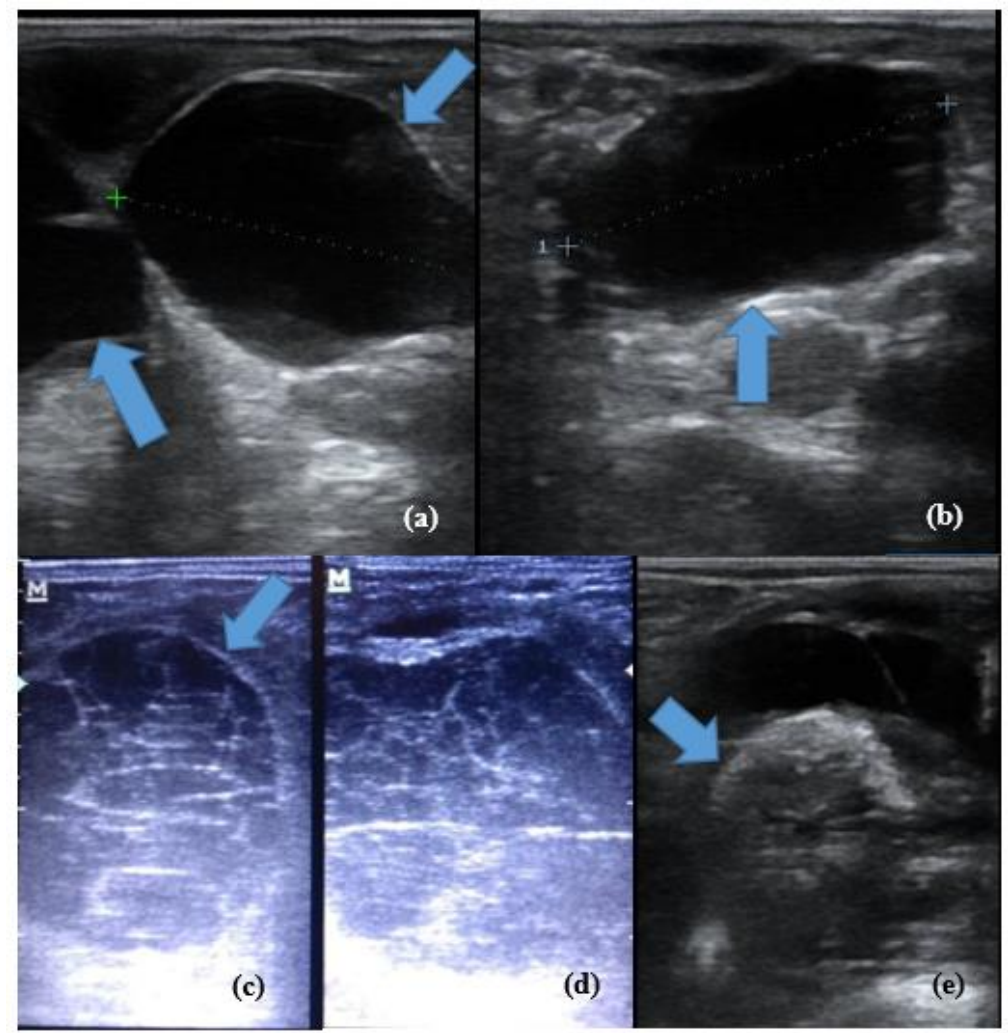

Fonte: Autores 
Foi coletada amostra de secreção uterina para realização de exame citológico e cultura bacteriana, a fim de avaliar possível infertilidade de causa infecciosa. No entanto, os achados citológicos e microbiológicos não revelaram presença de patógenos.

Após 8 meses, depois de várias tentativas sem sucesso no intuito de produzir uma gestação, optou-se pela remoção cirúrgica do $\mathrm{OE}$, diante do diagnóstico presuntivo de tumor ovariano.

Antes e após a cirurgia foram realizadas dosagens hormonais de estradiol, progesterona e testosterona (Tabela 1 e 2) com o intuito de investigar, documentar e confirmar o diagnóstico clínico, assim como descartar outras causas potenciais das alterações comportamentais e da infertilidade observadas. Amostras de sangue com a fêmea na fase de diestro foram coletadas em intervalo de quatro horas durante 24 horas, antes e após a ovariectomia. Em seguida, as amostras foram submetidas à análise laboratorial pelo método de quimioluminescência. Nas tabelas citadas estão expressas as médias dos valores obtidos nas 24 horas, descriminando a fase do ciclo estral e referentes a estradiol, progesterona e testosterona.

Tabela 1 - Média dos valores obtidos a partir das análises hormonais séricas coletadas em intervalos de 4 horas durante 24 horas no período pré-ovariectomia.

\begin{tabular}{lccc}
\hline Variável & Estradiol & Progesterona & Testosterona \\
\hline Dosagem no diestro & $58,9 \mathrm{pg} / \mathrm{ml}$ & $0,70 \mathrm{ng} / \mathrm{ml}$ & $<20,0 \mathrm{ng} / \mathrm{ml}$ \\
Referencia em diestro & $16,8-19,8 \mathrm{pg} / \mathrm{ml}$ & $>1,0 \mathrm{ng} / \mathrm{ml}$ & $<50,0 \mathrm{ng} / \mathrm{ml}$ \\
\hline
\end{tabular}

Fonte: Laboratório Vettings

Tabela 2 - Média dos valores obtidos a partir das análises hormonais séricas coletadas em intervalos de 4 horas durante 24 horas no período pós-ovariectomia.

\begin{tabular}{lccc}
\hline Variável & Estradiol & Progesterona & Testosterona \\
\hline Dosagem no diestro & $35.9 \mathrm{ng} / \mathrm{ml}$ & $4,91 \mathrm{ng} / \mathrm{ml}$ & $45,4 \mathrm{ng} / \mathrm{ml}$ \\
Referencia em diestro & $16,8-19,9 \mathrm{pg} / \mathrm{ml}$ & $>1.0 \mathrm{ng} / \mathrm{ml}$ & $<50,0 \mathrm{ng} / \mathrm{ml}$ \\
\hline
\end{tabular}

Fonte: Laboratório Vettings

No dia 13 de dezembro de 2018, a égua foi encaminhada para o Hospital Veterinário Metropolitano (HVM), localizado no município de Caucaia - Ceará. A paciente deu entrada no HVM e foi direcionada para o tronco de contenção, submetida a mais um exame ultrassonográfico do trato reprodutivo, não apresentando mudanças significativas. Foram realizadas a tricotomia e a antissepsia com Polivinil Pirrolidona Iodo (Riodeine 
Dermo Suave Degermante ${ }^{\circledR}$ ), Digliconato de Clorexidina 2\% (Riohex 2\%®) e álcool 70\%, na região do flanco esquerdo.

A veia jugular foi canulada com o uso de cateter intravenoso $n^{\circ} 14$, sendo realizada sedação com $20 \mu \mathrm{g} / \mathrm{kg}(0,2 \mathrm{ml} / 100 \mathrm{~kg})$ de Cloridrato de Detomidina (Dormium V®), manutenção com infusão continua com $60 \mu \mathrm{g} / \mathrm{kg} / \mathrm{h}(0,6 \mathrm{ml} / 100 \mathrm{~kg})$ de Cloridrato de Detomidina e $0.1 \mathrm{mg} / \mathrm{kg} / \mathrm{h}$ de Morfina juntas em um litro de soro $\mathrm{NaCl}$ 0,9\%, $1.3 \mathrm{mg} / \mathrm{kg} / \mathrm{h}$ de lidocaína 2\% sem vaso constritor em infusão contínua em 1 litro de soro $\mathrm{NaCl}$ 0,9\%, no local da incisão cirúrgica foi realizado bloqueio loco-regional em L invertido com $150 \mathrm{ml}$ de lidocaína $2 \%$ sem vaso constritor como também no pedículo ovariano antes da utilização do emasculador.

A ovariectomia unilateral esquerda foi realizada por laparotomia com a fêmea na posição quadrupedal. Para acessar o ovário foi realizada incisão de pele de aproximadamente $20 \mathrm{~cm}$ de comprimento no sentido vertical no flanco esquerdo. Seguiu-se com a divulsão dos tecidos, rompendo-se as fibras dos músculos oblíquo abdominal externo, interno e transverso, respectivamente. Rompeu-se o peritônio, alcançando-se, então, a cavidade abdominal. Com a exteriorização do ovário da cavidade abdominal, o pedículo ovariano foi emasculado e ligado com fio de sutura sintético absorvível no 0 do tipo Acido Poliglicólico (Vicryl@) (Figura 3). 
Figura 3 - Cirurgia de ovariectomia Unilateral Esquerda. Chegada do animal no Hospital Veterinário Metropolitano (a). Procedimento de tricotomia e antissepsia na região cirúrgica (b). Incisão de 20 centímetros de comprimento no sentido vertical no flanco esquerdo (c).

Divulsão dos tecidos (d). Exteriorização do ovário da cavidade abdominal (e). Pedículo ovariano emasculado e ligado com fio de sutura Vicryl ${ }^{\circledR} \mathrm{n}^{\circ} 0$ (f). Ovário esquerdo removido $(\mathrm{g}, \mathrm{h}, \mathrm{i})$.

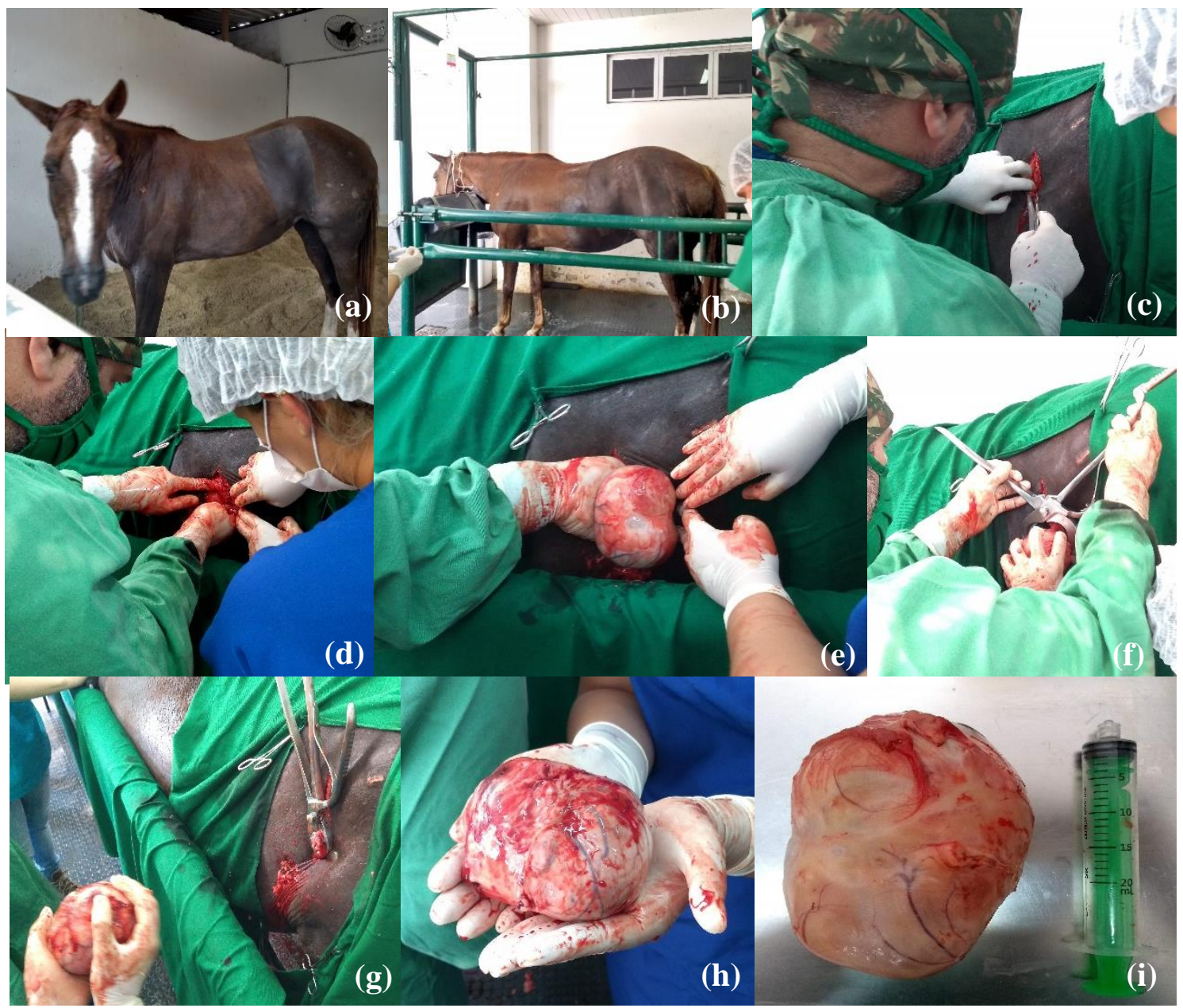

Fonte: Autores

Foi lançado na cavidade abdominal solução contendo $1600 \mathrm{mg}$ de Gentamicina (Gentatec ${ }^{\circledR}$ ), $60 \mathrm{ml}$ de Dimetilsulfóxido - DMSO (Dimesol®) diluídos em 1 litro de soro $\mathrm{NaCl}$ 0,9\%, seguindo-se a sutura do peritônio em conjunto com o músculo transverso,

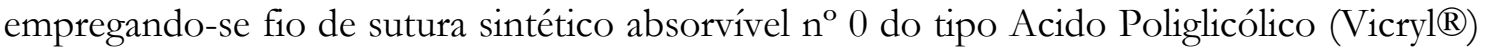
com padrão de sutura contínuo tipo Reverdin. Na sequência, realizou-se a sutura dos músculos oblíquo abdominal interno e externo, utilizando-se o mesmo fio e padrão de sutura. Finalmente, realizou-se a dermorrafia, com fio de nylon $n^{\circ} 2$, em sutura padrão simples tipo Wolff (Figura 4). 
Figura 4 - Dermorrafia com fio de nylon n ${ }^{\circ}$, em sutura padrão simples tipo Wolff

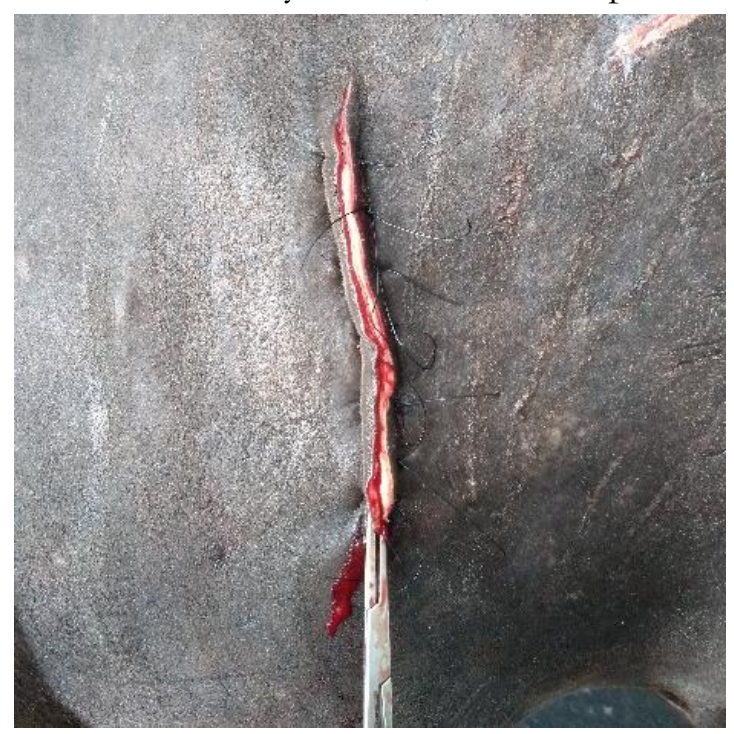

Fonte: Autores

O ovário removido foi armazenado em gelo e imediatamente foi encaminhado para exames laboratoriais, submetido à aspiração folicular em busca de oócitos e em seguida para exame histopatológico.

No pós-operatório imediato foi utilizado Flunixin meglumine (Flunixin $\left.{ }^{\circledR}\right)$ na dose de $1,1 \mathrm{mg} / \mathrm{kg}$ por via endovenosa, SID, por cinco dias consecutivos; antimicrobiano à base de Benzilpenicilina G, Procaína, Benzilpenicilina G Benzatina e Dihidroestreptomicina, associado a um anti-inflamatório não-hormonal Piroxicam (Pencivet ${ }^{\circledR}$ Plus PPU) na dose de 375 U.I/ $\mathrm{kg}$ de Benzilpenicilina por via intramuscular, BID, por cinco dias, $1600 \mathrm{mg}$ de Gentamicina (Gentatec $\left.{ }^{\circledR}\right)$ diluído em 1 litro de soro, por via endovenosa, SID, por cindo dias. Além das aplicações, higienização diária da ferida cirúrgica com iodopovidona seguida da aplicação de repelente tópico (Spray Bactrovet Prata $\left.{ }^{\circledR}\right)$.

Após cinco dias, estabeleceu-se alta hospitalar e a retirada dos pontos foi realizada após 15 dias do procedimento.

\section{Aspiração folicular}

O ovário removido foi submetido a punções foliculares em busca de oócitos, porém nenhum oócito foi encontrado no conteúdo aspirado. Durante as aspirações, a coloração e viscosidade do conteúdo variaram entre transparente, pouco amarelado, amarelado mais escuro, amarronzado e preto viscoso (Figura 5). 
Figura 5 - Punção folicular guiada por ultrassonografia (a,c). Conteúdo dos folículos apresentando coloração amarelada, transparente e preta $(a, b, d)$.

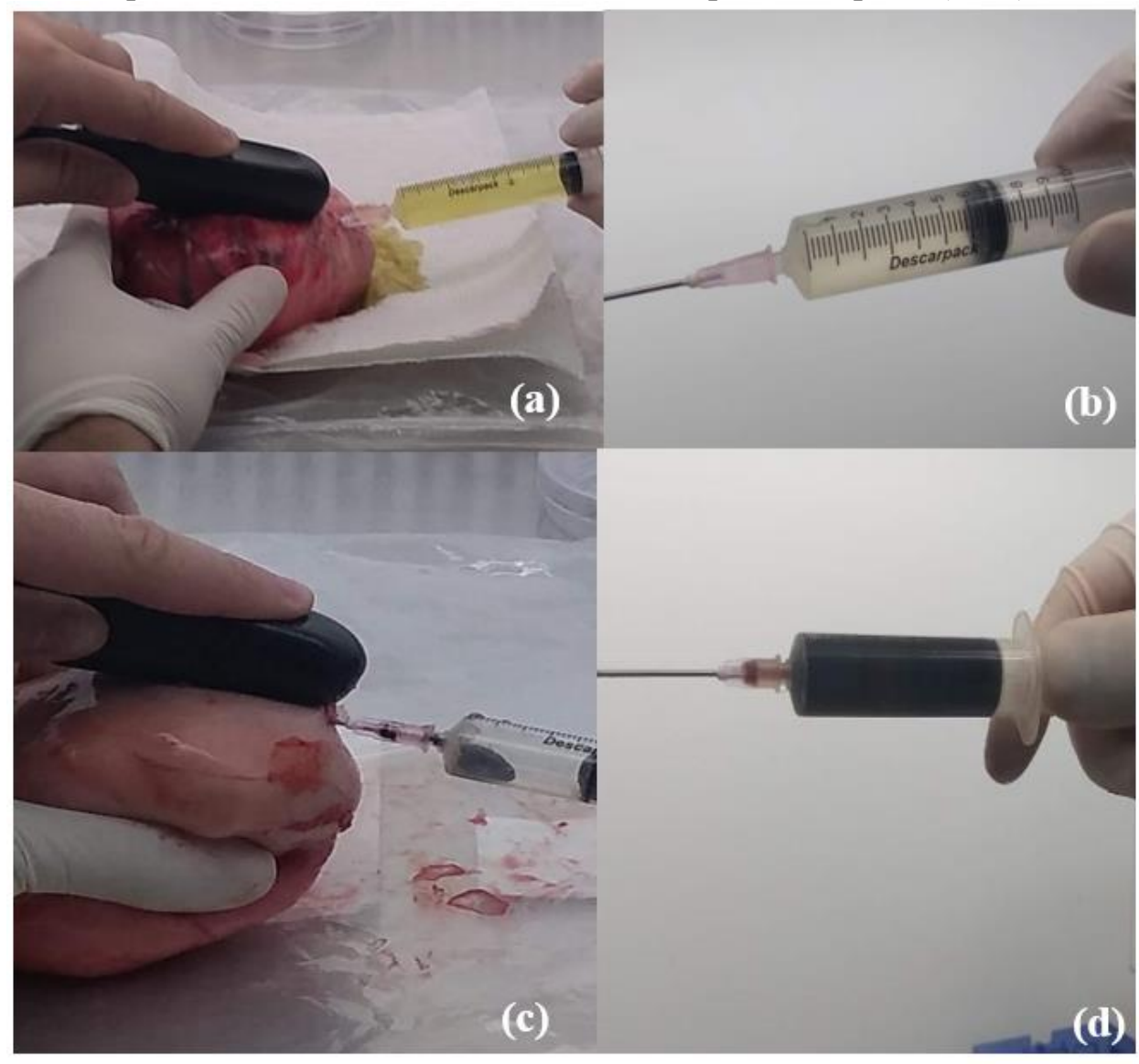

Fonte: Autores

Características Macroscópicas

O ovário removido era irregular, ovoide, possuía zonas avermelhadas e amareladas, pesava $0,940 \mathrm{~kg}$ e media cerca de 14,0 x 10,0 x 5,5 cm após drenagem do fluido. Possuía consistência firme e ao corte, a superfície revelou múltiplas cavidades císticas de tamanhos variados, entremeadas a feixes fibrocartilaginosos e ocasionais fragmentos pilosos arranjados em tufos. Havia, ainda, em um de seus polos, cavitação cística contendo conteúdo pardacento e friável, medindo $2,0 \mathrm{~cm}$ de diâmetro e uma cavidade contendo conteúdo denso e amarelado (Figura 6). 
Figura 6 - Ovário esquerdo removido pesando 0,940 kg e medindo cerca de 14,0 x 10,0 x $5,5 \mathrm{~cm}$ após drenagem do fluido, de consistência firme. Ao corte, a superfície revelou múltiplas cavidades císticas de tamanhos variados entremeadas a feixes fibrocartilaginosos e ocasionais fragmentos pilosos arranjados em tufos.

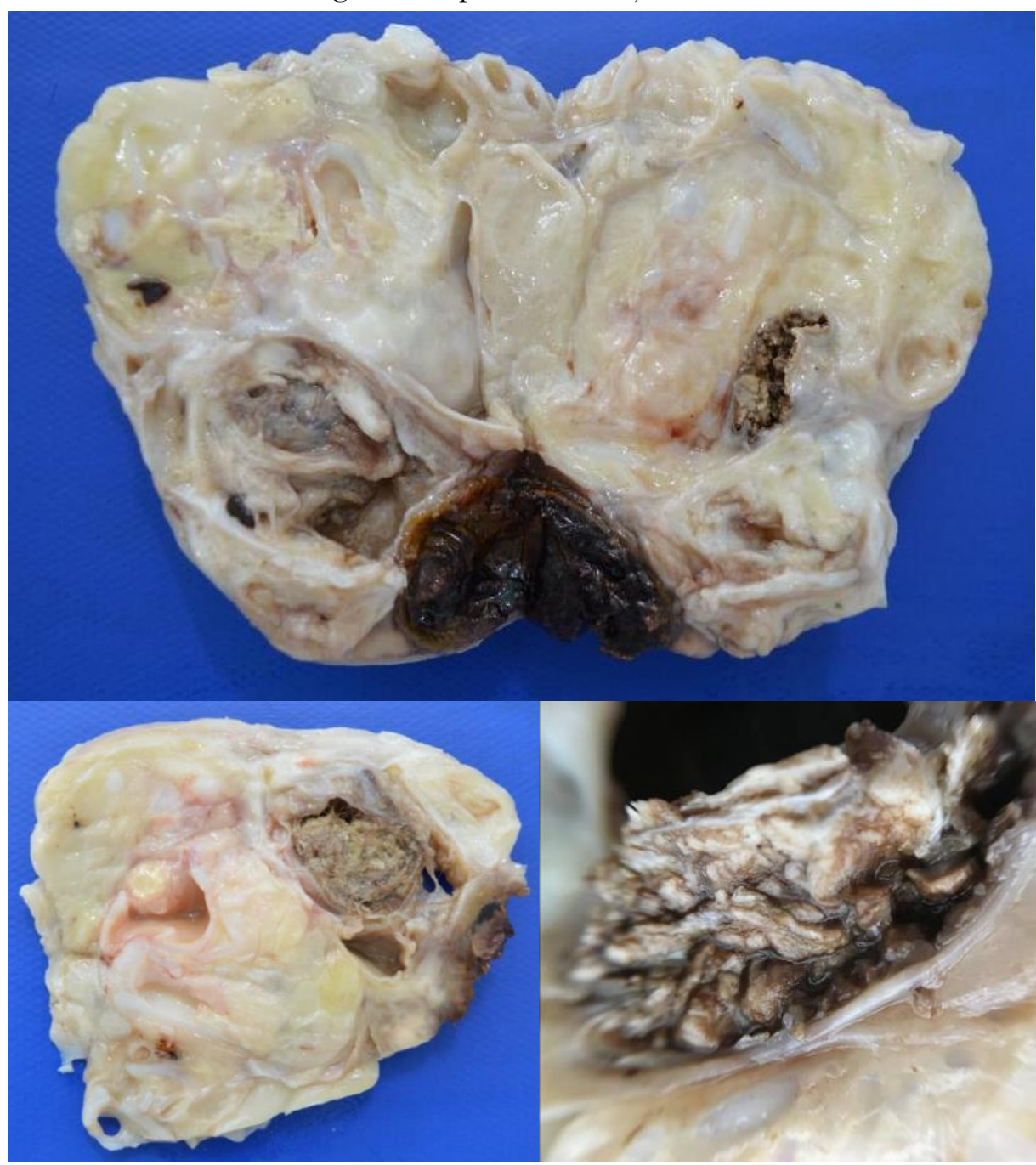

Fonte: Autores

\section{Análise Histopatológica}

Várias amostras do tecido ovariano foram selecionadas aleatoriamente e fixadas em formaldeído 4\% para exame histopatológico. As secções histopatológicas exibiram grande diversidade de tecidos compondo neoplasia bem diferenciada com áreas de pele, tecido respiratório e nervoso bem diferenciados. Havia ainda glândulas adrenais imaturas, tecido fibrocartilaginoso e área cística papilar revestida por epitélio maligno com múltiplas vesículas de decaptação. Discreto processo inflamatório crônico ativo foi observado, assim como 
focos de hemorragia. O quadro histopatológico se caracterizou como compatível com teratoma maligno.

O diagnóstico diferencial para hipertrofia ovariana deve incluir condições não neoplásicas (folículo anovulatório, hematoma ovariano, abscesso ovariano), bem como condições neoplásicas (TCG, Teratoma, Disgerminoma e Linfossarcoma) (LEFEBVRE, 2005).

Os folículos anovulatórios são a principal causa do aumento do tamanho ovariano (FRAZER, 1986), podendo se apresentar grandes (5 a $15 \mathrm{~cm}$ de diâmetro), persistir por até 2 meses, e resultar em comportamento estral anormal e intervalos interovulatórios prolongados (MEYERS,1995). Folículos anovulatórios também podem conter sangue e são consequentemente, muitas vezes denominados folículos hemorrágicos. No presente caso, o exame ultrassonográfico apresentou folículos anovulatórios no OE, podendo estar relacionado aos sinais de estro exacerbados observados na fêmea do presente relato.

Os hematomas do ovário são resultantes de uma hemorragia excessiva no lúmen folicular após a ovulação, sendo geralmente muito grandes (MCCUE, 1998). Ao exame ultrassonográfico, o folículo preenchido com sangue, inicialmente, aparece hipoecóico e quando o coágulo sanguíneo se torna mais organizado, a aparência fica manchada. O ovário pode levar meses para retornar ao tamanho normal e à ecogenicidade. No entanto, os hematomas nem sempre estão associados à infertilidade (BLANCHARD, 2003). Ressalta-se que no presente caso, o exame ultrassonográfico não foi compatível com hematoma.

Por sua vez, os abscessos ovarianos são geralmente unilaterais e apresentam aspecto hiperecogênico homogêneo ao exame ultrassonográfico. Tais observações ultrassonográficas não foram verificadas no caso descrito.

Tumores ovarianos são raros em éguas e são provenientes dos tecidos ovarianos, onde são classificados de acordo com sua origem celular em: tumor de células germinativas, TCG, tumor de células da teca e tumores mesenquimatosos (HARLAND, 2009). Nesta categoria, o TCG é o tumor ovariano mais comumente relatado (SUNDBERG, 1997). Geralmente, a ultrassonografia transretal do ovário afetado com TCG revela estrutura multicística ou em favo de mel, uma massa sólida ou um único grande cisto (MCCUE, 1998). No presente caso, as imagens ultrassonográficas apresentaram ecogenicidade mais homogênea condizentes com uma massa tumoral.

Tumores localizados no estroma ovariano secretam vários hormônios, incluindo progesterona, estradiol e testosterona, sendo a dosagem hormonal um complemento útil para diagnóstico diferencial (WATSON, 2002). As células da granulosa e da teca geralmente 
coexistem na mesma neoplasia e produzem hormônios diferentes, variando as características clínicas da doença. Na presença de tumor de células granulosa/teca ou GTCT, a testosterona é elevada em aproximadamente 50 a $60 \%$ das éguas afetadas e é geralmente associado ao comportamento parecido com um garanhão (MCCUE, 1998). No caso em estudo, a égua não apresentava tal comportamento e a dosagem de testosterona encontrada antes da cirurgia foi $<20,0 \mathrm{ng} / \mathrm{ml}$, enquanto o valor de referência normal para égua não gravídica é de $<50,0$ $\mathrm{ng} / \mathrm{ml}$.

Já os níveis de progesterona em éguas normais aumentam após a ovulação (diestro) e estão em níveis basais no cio ou anestro, podendo aumentar em éguas com anormalidades ovarianas transitórias, tais como luteinização, folículos anovulatórios ou hematomas ovarianos luteinizados. Em contraste, a progesterona não é produzida por tumores ovarianos (MCCUE, 2013). No caso em estudo, o nível de progesterona encontrado antes da cirurgia foi de $0,70 \mathrm{ng} / \mathrm{ml}$, abaixo do valor normal na fase do diestro $>1,0 \mathrm{ng} / \mathrm{ml}$. Após a ovariectomia, os valores encontrados pelas dosagens de estradiol, progesterona e testosterona se aproximaram dos valores normais de acordo com a fase do ciclo estral (Tabela 1 e 2$)$.

No presente caso, o animal apresentou alguns episódios de libido exacerbada; que podem estar correlacionados com folículos anovulatórios que se desenvolveram e com a neoplasia (MCCUE, 1998), como o teratoma diagnosticado nesse caso. Ressalta-se que o exame histopatológico foi decisivo para o diagnóstico diferencial do teratoma, reforçando a hipótese de que não se tratava de um TCG.

Embora o teratoma seja considerado o segundo tumor ovariano mais frequente em cavalos, é uma condição muito rara (MCCUE, 1998). No caso de teratomas ovarianos em éguas, a terapia recomendada é a ovariectomia (PUGH et al., 1985). Para um diagnóstico preciso e tratamento eficaz, é necessário levar em consideração o temperamento da égua, as exigências do proprietário do animal, a acomodação cirúrgica e o tipo de tumor ou aumento de volume. Para um diagnóstico final, o exame histopatológico de diferentes amostras do ovário removido é crucial (VANHAESEBROUCK et al., 2010). 


\section{CONCLUSÃO}

O teratoma ovariano é uma patologia rara em égua, que causa infertilidade, devendo ser diferenciado de outras patologias que afetam os ovários. A avaliação da história reprodutiva completa da fêmea e a realização de uma série de exames transretais e ultrassonográficos durante um certo período de tempo são necessários para estabelecer um diagnóstico clínico presuntivo. No entanto, para o diagnóstico final, o exame histopatológico do tecido ovariano é essencial para verificação de condição rara de malignidade do teratoma.

\section{REFERÊNCIAS}

Bailey Mt, Troedsson MHT, Wheaton JE. Inhibin concentrations in mares with granulose cell tumors. Theriogenology 2002;57: 1885-1895.

Blanchard TL, Varner D, Schumacher J, Love CC, Brinsko SP, Rigby SL. Manual of Equine Reproduction. 2nd ed, Toronto: Mosby, 2003:43-57.

Frazer G.S., Robertson J.T., Boyce R.W. (1988). Teratocarcinoma of the ovary in a mare. Journal of the American Veterinary Medical Association 193, 953-955.

Frazer GS, Threlfall WR. Differential diagnosis of enlarged ovary in the mare. Proc 32th Annu Conv Am Assoc Equine Pract, 1986: 21-28.

McCue P.M. (2013). Granulosa cell tumor in a mare. Equine Reproduction Case Files. 3, 1 7.

McCue P.M. (1998). Neoplasia of the female reproductive tract. Veterinary Clinics of North America Equine Practice 14, 505-515.

Mckinnon AO, Squires EL, Vaala WE, Varner DD. Diseases of the ovary and oviduct. Section L. In: Mckinnon AO, Squires EL, Vaala WE, Varner DD. (Ed.). Equine reproduction. 2nd ed. Oxford: Wiley Blackwell. 2011; 279-282.

Meyers PJ. Ovary and oviduct. In: Kobluk CN, Ames TR, Geor RJ, eds. The horse. Philadelphia: Saunders, 1995; 999-1004.

Nie G.J., Momont H. (1992). Ovarian mass the three mares with regular estrous cycles. Journal of American Veterinary Medical Association 201, 1043-1044.

Oliveira F.G., Dozortsev D., Diamond M.P., Fracasso A., Abdelmasih S., Adbelmassih V., Gonçalves S.P., Abdelmasih R., Nagy Z.P. (2004). Evidence of parthenogenetic origin of ovarian teratoma: case report. Human Reproduction 19, 1867-1870.

Watson ED, Heald M, Leask R, Groome NP, Riley SC. Detection of high circulating concentrations of inhibin pro- and $-\alpha \mathrm{C}$ immunoreactivity in mares with granuloas-theca cell tumors. Equine Vet J. Vol. 34, pag.203-206, 2002. 
Outwater EK, Siegelman ES, Hunt JL. 2001. Ovarian teratomas: tumour types and imaging characteristics. Radiographics. 21:475490.

Pugh DG, Bowen JM, Gaughan EM, 1985: Equine ovarian tumors. Compend Cont Educ Pract Vet Suppl 7, 5710-5717.

Sundberg JP, Burnstein T, Page EH, Kirkham WW, Robinson FR. Neoplasm of Equidae. J Am Vet Med Assoc 1977;170:150-152.

Van Camp S.D., Mahler J., Roberts M.C., Tate L.P., Whitacre M.D. (1989). Primary ovarian adenocarcinoma associated with teratomatous elements in a mare. The Journal of American Veterinary Medical Association 194, 1728- 1730.

Vanhaesebrouck E., Govaere J., Smits K., Durie I., Vercauteren G., Martens A,. Schauvliege S., Ducatelle R., Hoogewijs M., De Schauwer C., Kruif A (2010). Ovarian teratoma in the mare: a review and two cases. Vlaams Diergeneeskundig Tijdschrift, 79, 32-41.

Vicus D, Beiner ME, Clarke B, Klachook S, Le LW, Laframboise S, Mackay H. Ovarian immature teratoma: treatment and outcome in a single institutional cohort. Gynecologic Oncology. 2011; 123(1):50-53. doi: 10.1016/j.ygyno.2011.06.037.

Westermann C.M., Parlevliet J.M., Meertens N.M., Sloet M.M. (2003). Een vergroot ovarium bij de merrie, een literatuuroverzicht aan de hand van een casus. Tijdschrift voor Diergeneeskunde 128(22), 692-696. 


\section{FISIOLOGIA REPRODUTIVA BÁSICA DA FÊMEA CANINA}

\section{Paula Magnabosco Secco}

Aprimoranda do PAMV, UNICENTRO, Departamento de Medicina Veterinária, Guarapuava, PR

Lattes: http://lattes.cnpq.br/8070426735091307

\section{Carla Fredrichsen Moya}

Docente, UNICENTRO, Departamento de Medicina Veterinária, Guarapuava, PR Lattes: http://lattes.cnpq.br/8017623096370725

Informações sobre o

artigo:

Recebido em:

$10 / 05 / 2021$

Aceito em:

13/05/2021

Data de publicação:

19/07/2021

Palavras-chave:

Cães

Manejo

Reprodutivo

Hormônios

\section{RESUMO}

O atual número de cães presentes no mundo reflete a importância dessa espécie no convívio com os seres humanos. Ao buscar aprimorar as raças existentes, gerando exemplares mais saudáveis, de bom temperamento e aptos às tarefas a eles exigidas, a reprodução assistida torna-se uma condição necessária. Além disso, o cão doméstico serve como um modelo para o aperfeiçoamento de técnicas reprodutivas visando a preservação de canídeos ameaçados de extinção. A cadela pode ser classificada como monoéstrica, com ovulação espontânea e não estacional para a maioria das raças. O ciclo estral é dividido em quatro fases: em média, seis a nove dias de proestro, seis a nove dias de estro, dois meses de diestro e três a quatro meses de anestro. As diferenças inerentes a cada fase do ciclo podem ser identificadas pelo comportamento da fêmea, pelas características dos órgãos reprodutivos, pela citologia vaginal ou dosagem hormonal. A determinação do intervalo de maior fertilidade da cadela pode ser realizada associando-se dois ou mais desses métodos. Conhecer com precisão esse intervalo é útil quando se intenciona utilizar a inseminação artificial com sêmen refrigerado, congelado ou de qualidade inferior. A inseminação artificial, juntamente com a criopreservação de sêmen e a indução da ciclicidade são as biotécnicas reprodutivas mais utilizadas em cães. Conhecer as particularidades reprodutivas dos cães, sobretudo da fêmea, possibilita empregar com sucesso essas biotécnicas e aprimorar o uso de outras ainda infrequentes nessa espécie.

\section{BASIC REPRODUCTIVE PHYSIOLOGY OF THE CANINE} FEMALES

The great number of dogs currently living in the world reflects the importance of this species for the human society. By seeking to improve the actual breeds, generating healthier specimens, with good temperament and fit to the tasks required of them, assisted reproduction becomes a necessary condition. Furthermore, the domestic dog serves as a model for the improvement of reproductive techniques aimed at the preservation of wild, endangered canids. The bitch can be classified as monoestric, spontaneous ovulation and non-seasonal for most breeds. The 
Keywords:

Breeding

Management

Canine

Female estrous cycle is divided into four phases: average six to nine days proestrus, six to nine days estrus, two months diestrus and three to four months anestrus. The differences in each phase can be identified by the female behavior, by the characteristics of the reproductive tract, vaginal cytology or hormonal assays. Setting the bitch's most fertile days can be better accomplished by associating two or more of these methods. Knowing this timing accurately is useful when seeking to use artificial insemination with chilled, frozen or low-quality semen. Artificial insemination, along with cryopreservation of the semen and cyclicity induction are the most widely used reproductive techniques in dogs. Knowing the canine reproductive peculiarities, especially in the bitch, makes it possible to successfully employ these techniques and improve those that are still uncommon in this species.

\section{INTRODUÇÃO}

A convivência e parceria entre cães e seres humanos é uma das mais antigas já registradas. Desde a domesticação, o relacionamento entre homem e cachorro se intensificou, e os cuidados e gastos com os cães aumentaram consideravelmente (KOLERMATZNICK, 2002; SINGH et al., 2019). Em 2018, o Instituto Pet Brasil atualizou o último levantamento pelo IBGE, apontando um total de 54,2 milhões de cães no país contra cerca de 470 milhões em todo o mundo, garantindo a segunda colocação mundial, atrás apenas dos Estados Unidos. Segundo dados aferidos no mesmo período, o número de cães no Brasil superava o número de crianças e jovens de zero a 14 anos, os quais totalizavam 41,4 milhões (IBGE, 2018; INSTITUTO PET BRASIL, 2019). Estima-se, também, que 46,1\% dos lares brasileiros possuam ao menos um cão, o que corresponde a 33,8 milhões de domicílios (IBGE, 2019).

As estratégias reprodutivas utilizadas pelos seres humanos com os cães surgiram com o objetivo de criar raças destinadas a diferentes propósitos que melhor serviam às necessidades de seus proprietários (VILÀ, LEONARD, 2007). Hoje em dia, são conhecidas mais de 400 raças de cães, dentre as quais incluem, por exemplo, as destinadas à companhia, ao trabalho, à guarda e ao pastoreio (FCI, 2021).

A primeira inseminação artificial relatada na veterinária foi realizada em uma cadela pelo cientista italiano Lazzaro Spallanzani em 1784, o que resultou em uma ninhada de três filhotes (ORLAND, 2017). Embora, hoje, o uso da inseminação artificial esteja já bastante difundido nessa espécie, algumas técnicas mais avançadas que envolvem manipulação de 
gametas e embriões, largamente utilizadas em animais de produção, são ainda atrasadas nos animais de companhia (LUVONI et al., 2006). Assim sendo, o aperfeiçoamento dessas técnicas e a obtenção de sucesso na reprodução canina requer o conhecimento acerca das particularidades reprodutivas da espécie, e é essencial na busca pelo melhoramento genético das raças existentes (WANG, 2018).

A seleção criteriosa de reprodutores e matrizes e o uso adequado das técnicas reprodutivas garantem gerações de animais com superioridade genética, ou seja, menos inclinados a desenvolver doenças predisponentes, com bom temperamento, e aptos às tarefas impostas pela raça a que pertence (DUFFY; SERPELL, 2012; GODDARD; BEILHARZ, 1982; MAEJIMA et al., 2007; SWENSON et al., 1997). O uso da reprodução assistida em cães também serve como modelo de estudo para espécies de canídeos selvagens ameaçados de extinção, técnicas que podem ser posteriormente melhoradas e usadas na manutenção e prevenção da biodiversidade (LUVONI, 2000).

Esse trabalho tem como objetivo fazer uma revisão acerca da fisiologia reprodutiva da fêmea canina, abrangendo as particularidades do ciclo estral e comportamento sexual, associando essas informações ao uso das biotécnicas mais difundidas na reprodução dessa espécie.

\section{REFERENCIAL TEÓRICO}

\subsection{Ciclo estral da fêmea canina}

Os eventos endócrinos básicos que regulam a ciclicidade da cadela são similares aos da maioria das espécies domésticas já estudadas. Isso é, a predominância do estrógeno na fase folicular, levando ao pico do hormônio luteinizante e ovulação e ao comportamento de estro; predomínio progesterônico durante a fase luteínica no intuito de preparar o organismo da fêmea para a gestação; e o papel do hipotálamo como regulador do ciclo estral e reprodução. Entretanto, a forma e o período em que esses eventos ocorrem e as consequentes respostas fisiológicas às ações e interações hormonais diferem na cadela e tornam-na uma espécie única no estudo da reprodução animal (CONCANNON, 2011; SCHATTEN; CONSTANTINESCU, 2007).

O ciclo estral da fêmea canina pode ser dividido em quatro fases: proestro, estro, diestro e anestro. O intervalo entre estros é de cinco a 12 meses, variando entre cadelas e em ciclos diferentes de uma mesma cadela (CONCANNON, 2011). O longo período interestro classifica essa espécie como mono ou diéstrica anual, sem influência da estação do ano para 
a maioria das raças, com exceção do basenji que apenas cicla uma única vez ao ano, no outono (JOHANNES, 2003; SOKOLOWSKI et al., 1977).

O proestro é a primeira evidência de fertilidade da cadela, na qual ela inicia a produção de feromônios atrativos aos machos, presentes nas secreções vaginais, sem, no entanto, aceitar a monta (CONCANNON, 2011). Nessa fase, ocorre o recrutamento e crescimento dos folículos pré-ovulatórios, o que resulta em níveis estrogênicos cada vez mais altos, chegando a atingir valores entre 50 e $100 \mathrm{pg} / \mathrm{mL}$ (CONCANNON et al., 1989). England et al. (2009) demonstraram em seu estudo sobre a dinâmica folicular de cadelas um rápido aumento no número de folículos presentes em cada ovário no início do proestro (oito folículos pequenos) em comparação com o anestro anterior (dois folículos pequenos) e uma média de quatro a cinco folículos pré-ovulatórios por ovário ao final dessa fase.

Os altos níveis de estrógeno provocam mudanças fisiológicas na fêmea, facilmente identificadas pelo proprietário ou médico veterinário. Como exemplo, nota-se o edema e rubor da vulva, frequentemente acompanhados de secreção vaginal serosanguinolenta (Figura 1A), mucosa vaginal edemaciada, rósea a avermelhada e lubrificada na vaginoscopia; e um paulatino aumento de células superficiais com núcleo picnótico ou anucleadas resultantes da proliferação do epitélio, e presença de eritrócitos lisados ou intactos na citologia vaginal (JEFFCOATE, LINDSAY, 1989; KUSTRITZ, 2012).

Diferentemente das demais espécies domésticas, porém de modo similar ao que acontece na mulher e em alguns roedores, a cadela apresenta uma luteinização pré-ovulatória dos folículos, e é responsável pela produção inicial de pequenas quantidades de progesterona e consequente redução dos valores de estrógeno, levando às mudanças de coloração e turgidez dos órgãos reprodutivos e do comportamento da fêmea na medida em que o proestro adianta-se em relação ao estro (ASA, VALDESPINO, 1998; CONCANNON et al., 2009; CONCANNON, 2011). Portanto, ao final dessa fase, observa-se na vagisnoscopia uma regressão do edema de vulva e vagina e a descoloração das mucosas. Além disso, a atitude da fêmea em relação ao macho passa de agressiva a tolerante ou brincalhona. $\mathrm{O}$ proestro pode durar de três até 21 dias, com média de nove dias, e o término dessa fase, endocrinologicamente coincide com a onda pré-ovulatória de LH (CONCANNON, 2011; FORSBERG, 2001). 
Figura 1 - (A) Vulva de cadela edemaciada com presença de secreção serosanuinolenta (seta azul); (B) Lâmina de citologia vaginal, com presença de células superficiais anucleadas (escamas), características da fase de estro.

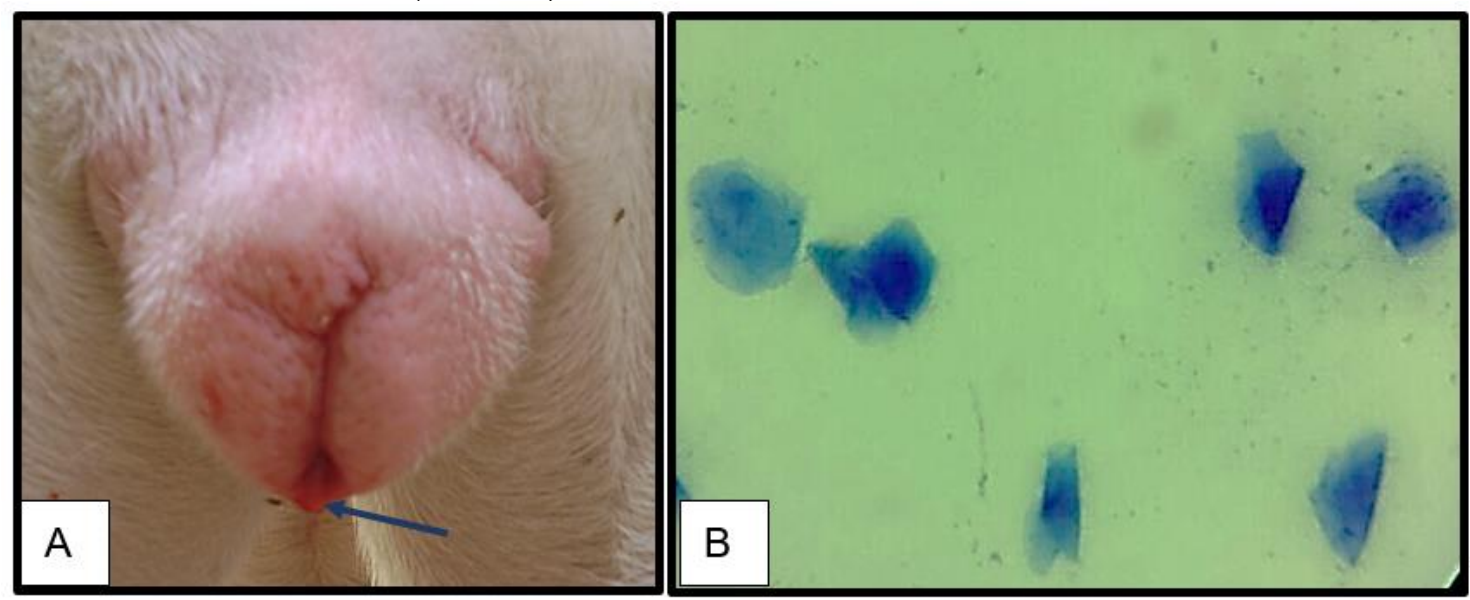

Fonte: Autores

Com relação ao comportamento, a fase de estro é iniciada quando a fêmea passa a aceitar a monta e a procurar o macho, o que ocorre normalmente cerca de dois dias antes do pico pré-ovulatório de LH, quando os níveis de progesterona aumentam simultaneamente à queda dos níveis de estrógeno (CONCANNON, 2009). A duração média dessa fase é similar a anterior, nove dias, no entanto, variações no comportamento da cadela durante o estro podem ocorrer e estão relacionadas não somente aos níveis hormonais, mas também com o temperamento da fêmea, local escolhido para a cobertura e com o macho propriamente dito (CONCANNON et al., 1979; CONCANNON, 2011).

Após o pico de LH, os níveis de estrógeno caem para valores abaixo de 20 pg/mL, enquanto que os níveis de progesterona aumentam rapidamente de 1 a $2 \mathrm{ng} / \mathrm{mL}$ no final do proestro, chegando a $25 \mathrm{ng} / \mathrm{mL}$, dez dias após o começo do estro (CONCANNON, 2011). $\mathrm{Na}$ vaginoscopia, a mucosa mantém-se hipocorada e com um aspecto rugoso devido a drástica redução do edema. Em relação à citologia vaginal, 95 a 100\% do total celular observado é composto por células superficiais com núcleo picnótico ou anucleadas (Figura 1B). Algumas fêmeas podem manter o edema de vulva e vagina e secreção vaginal serosangramenta durante o estro, sem qualquer comprometimento da fertilidade (KUSTRITZ, 2012).

$\mathrm{Na}$ cadela, a ovulação é determinada por fatores endócrinos em momento específico do ciclo estral, sem interferência da cópula. No entanto, é difícil definir o período de maior fertilidade dessa espécie considerando apenas o início dos sinais de proestro ou estro, devido à grande variação na duração dessas fases (FORSBERG, 2001). O período mais consistente e confiável é aquele entre o pico do hormônio luteinizante e do início da 
ovulação, o qual fica entre 36 a 50 horas, enquanto que o processo ovulatório pode perdurar por até 96 horas (CONCANNON, 1993; CONCANNON, 2009; JEFFCOEATE, LINDSAY, 1989).

Além disso, na cadela, os oócitos são liberados ainda imaturos, na fase de prófase I, e o término das divisões meióticas e expansão das células do cúmulus ocorrem nos ovidutos, em um a dois dias (CONCANNON et al., 1989; TSUTSUI, 1989; YAMADA et al., 1993). Após maturados, os oócitos podem permanecer viáveis, em média, por mais quatro a seis dias, e considerando o tempo semelhante de sobrevida dos espermatozoides, a gestação na cadela pode ocorrer com um único acasalamento em praticamente qualquer momento do estro, o que justifica as altas taxas de fertilidade encontradas nessa espécie (CONCANNON et al., 2009). Todavia, quando se intenciona utilizar um sêmen refrigerado, congelado ou de qualidade inferior, o intervalo de maior fertilidade da fêmea a ser considerado é aquele compreendido entre quatro a sete dias após o pico de LH, no qual os oócitos já foram liberados e maturados (FORSBERG, 2001).

Como a ovulação está correlacionada com o pico de LH, a dosagem direta desse hormônio no sangue é o método comercialmente disponível, que melhor permite determinar o momento exato desse evento na cadela. No entanto, o teste muitas vezes não é acessível devido aos custos e necessidade de manejos frequentes de colheita de sangue e processamento das amostras, já que o período em que os níveis desse hormônio permanecem altos na corrente sanguínea é bastante curto (ENGLAND; RUSSO, 2008). A citologia vaginal, é capaz de identificar a fase do ciclo estral em que a fêmea se encontra, porém não é capaz de predizer o momento da ovulação, podendo ser utilizada para a indicar o dia da cópula ou inseminação (CONCANNON, 2011; KUSTRITZ, 2012).

A dosagem da progesterona busca contornar esse problema, e é atualmente o método mais utilizado para determinar o momento da ovulação. Normalmente, durante o pico de $\mathrm{LH}$, os níveis de progesterona encontram-se ao redor de $2 \mathrm{ng} / \mathrm{mL}$ e aumentam para 4 a 10 ng/mL na ovulação (JOHNSTON, ROOT, 1995). Contudo, devido à grande variação nas concentrações desse hormônio de cadela para cadela, recomenda-se a realização de dosagens seriadas, buscando acompanhar a evolução das concentrações e garantir maior confiabilidade do teste (KUSTRITZ, 2012). O término do estro pode ser definido quando a fêmea deixa de permitir a cópula, ou clinicamente pelo retorno da coloração rósea da vagina, com pequenos capilares visíveis e pela não mais predominância de células cornificadas na 
citologia vaginal, eventos que começam a ocorrer normalmente cerca de sete dias após o pico de LH (CONCANNON et al., 2009).

Os níveis de progesterona continuam a subir com a formação dos corpos lúteos, chegando aos valores máximos de 15 a $90 \mathrm{ng} / \mathrm{mL}$ após cerca de 20 dias do início do diestro (CONCANNON, 2005; EDQVIST et al., 1975). Nesses primeiros dias, a síntese de progesterona pelos corpos lúteos ocorre de forma independente, no entanto, a partir da segunda metade dessa fase, fatores luteotróficos como o LH e a prolactina são essenciais na sua manutenção, de modo que o bloqueio exógeno desses hormônios pode levar à luteólise ou a reduções drásticas nos níveis de progesterona (CONCANNON et al., 1987; OKKENS et al., 1986).

A duração média do diestro na espécie canina é de 60 dias, sendo semelhante entre cadelas prenhas e não-prenhas, porém ligeiramente menor em cadelas prenhas (ASA; VALDESPINO, 1998; KOWALEWSKI et al., 2011; OLSON et al., 1989). Enquanto que em cadelas cíclicas os níveis de prolactina aumentam até valores aproximados a $9 \mathrm{ng} / \mathrm{mL}$ ao final do diestro, em cadelas prenhas essa concentração pode atingir $50 \mathrm{ng} / \mathrm{mL}$ imediatamente anterior ao parto (CONCANNON et al., 2001; GRAF, 1978). Algumas cadelas nãogestantes, no entanto, podem apresentar um aumento dos níveis de prolactina, resultando num quadro conhecido como pseudo-gestação, no qual ocorrem mudanças no comportamento da fêmea, como nidificação e adoção de objetos, desenvolvimento mamário e secreção láctea (GOBELLO et al., 2000; TSUTSUI, et al., 2007).

O retrato celular observado na citologia vaginal durante a fase de diestro é uma predominância de células parabasais e intermediárias, células menos superficiais do epitélio, e um grande número de polimorfonucleares, como neutrófilos, que atravessam facilmente o epitélio da parede vaginal, adelgaçado pelos baixos níveis de estrógeno (CHANDRA; ADLER, 2008; KUSTRITZ, 2012). A partir da segunda metade do diestro, os níveis de progesterona decaem lentamente até valores inferiores a $1 \mathrm{ng} / \mathrm{mL}$, o que determina o início do anestro (OLSON et al., 1989).

Embora em cadelas prenhas a prostaglandina $\mathrm{F}_{2 \alpha}$ sintetizada pelo trofoblasto dos fetos, seja a principal responsável pela luteólise e desencadeamento do parto (KOWALEWSKI et al., 2010), em fêmeas cíclicas, a regulação de fatores luteotróficos, tanto na via endócrina, como principalmente parácrina e autócrina, parecem ser mais importantes na duração da viabilidade do corpo lúteo do que fatores luteolíticos (FERNANDES et al., 1987; OLSON et al., 1984; PAPA; KOWALEWSKI, 2020). A regressão lútea na cadela ocorre devido a uma progressiva degeneração do tecido luteínico, resultando em níveis cada 
vez menores de hormônios esteroides circulantes e numa estrutura completamente afuncional ao final do diestro (DORE, 1989).

As concentrações basais de esteroides e a inatividade ovariana caracterizam o anestro, período obrigatório no ciclo estral da fêmea canina (CONCANNON, 2011). Durante essa fase, as concentrações de LH são inferiores a $1 \mathrm{ng} / \mathrm{mL}$, apresentando pulsos com frequência de uma a seis vezes ao dia, enquanto que poucos dias antes do proestro, esse intervalo aumenta para até uma vez a cada hora e concentrações iguais ou superiores a 3 $\mathrm{ng} / \mathrm{mL}$, sendo que no pico pré-ovulatório esses níveis podem atingir $40 \mathrm{ng} / \mathrm{ml}$, com média ao redor de 10 a $15 \mathrm{ng} / \mathrm{mL}$ (CONCANNON et al., 2009). Os valores de FSH gradualmente aumentam com a progressão do anestro, juntamente com o estrógeno, o que pode estar relacionado com uma pré-seleção da população folicular para o próximo ciclo (JEFFCOATE, 1993; OKKENS; KOOISTRA, 2006). O anestro é essencial para a completa involução uterina e reparação histológica do endométrio, processos que necessitam de um período mínimo de sete semanas, mas que em média duram de três a cinco meses (CONCANNON et al., 2009; PO-YIN et al., 2006). As características observadas na vaginoscopia são semelhantes aquelas da cadela em diestro, enquanto que na citologia vaginal, há um predomínio marcante de células parabasais e raros ou nenhum neutrófilo presente (CONCANNON, 2011).

\subsection{Biotécnicas aplicadas a reprodução canina}

Algumas biotécnicas que são utilizadas na criação da espécie canina são a criopreservação de sêmen, indução da ciclicidade e inseminação artificial. Para a aplicação de qualquer uma dessas biotécnicas de reprodução é necessário o conhecimento sobre espermatogênese, ciclo estral da cadela, bem como os hormônios envolvidos em cada fase do mesmo.

A criopreservação de espermatozoides tornou-se uma ferramenta indispensável na reprodução. No entanto, o sêmen congelado/descongelado tem uma viabilidade menor no genital da fêmea devido à perda da integridade das células espermáticas (ALHAIDER; WATSON, 2009; SICHERLE et al., 2020). Os meios diluentes empregados na congelação de sêmen canino têm a gema de ovo como componente para auxiliar na proteção da integridade da membrana espermática. De acordo com Axnér e Lagerson (2016), a integridade da membrana espermática foi significativamente melhor no meio a base gema de 
ovo do que em diluente à base de lecitina. Contudo, a lecitina pode ser uma alternativa interessante para a criopreservação do sêmen, sem uso de proteina de origem animal.

De acordo com a literatura, a indução da ciclicidade em cadelas pode ser realizada empregando-se agonistas da dopamina (como a cabergolina), agonistas do hormônio liberador de gonadotrofinas $(\mathrm{GnRH})$ e gonadotrofina (FSH), mas cada tratamento tem suas vantagens e desvantagens. Apesar da ampla disponibilidade desses medicamentos em todo o mundo, não há um protocolo único e eficiente para a indução do estro em fêmeas caninas. O período de tratamento possui uma grande variação em dias para inicio da expressão do pró-estro e nem todas as fêmeas respondem ao protocolo (KUTZLER, 2018; MOGHEISEH et al., 2017; WALTER et al., 2011).

A inseminação artificial (IA) é uma biotécnica da reprodução, em que o sêmen do cão é colhido posteriormente depositado no genital da fêmea. As principais indicações para uso da IA são falhas na realização da monta natural por incapacidade do macho, agressividade dos reprodutores, incompatibilidade conformacional (raças braquicefálicas), diferentes localidades do macho e da fêmea ou quando pretende-se associar ao uso de sêmen refrigerado ou congelado (MASON, 2017; MASON, 2018). Como descrito anteriormente, o período fértil da cadela pode ser melhor acurado usando uma combinação de citologia e morfologia da mucosa vaginal, comportamento e dosagem hormonal, com destaque para a progesterona.

As formas, em que a IA pode ser feita são baseadas no tipo de sêmen que será utilizado. Assim, a IA pode ser por meio de deposição do ejaculado intravaginal (sêmen fresco ou refrigerado), intrauterina, por meio de endoscopia transcervical (sêmen refrigerado e congelado) e intrauterina através de celiotomia ou laparoscopia (sêmen congelado). O sucesso do procedimento está diretamente relacionado com a determinação do momento ideal, qualidade espermática e técnica empregada (JEFFCOATE; LINDSAY, 1989; MASON, 2017; MASON, 2018).

Segundo Moya et al. (2021) a IA intravaginal (IAIV) com sêmen fresco é a via de escolha na maioria dos casos, por ser de fácil execução e por oferecer bons resultados. Nesse mesmo estudo, utilizando citologia vaginal para acompanhamento do ciclo estral e escolha do momento das inseminações em cadelas da raça Buldogue Inglês, a taxa de prenhez foi de $87,50 \%(14 / 16)$. As ninhadas tiveram em média 5,66 $\pm 1,20$ filhotes, desses 53,16\% (42/79) eram machos e 46,84\% (37/79) fêmeas.

Já Hernandes et al. (2020) utilizando um estudo semelhante, porém associando à dosagem de progesterona, apresentou uma taxa de prenhez de 93,33\% (14/15), as ninhadas 
tiveram tamanho médio de $8 \pm 3$ filhotes, sendo que a porcentagem de fêmeas foi de 47,41\% (55/116) e de machos de 52,59\% (61/116).

A inseminação intra-uterina, por meio de celiotomia ou por laparoscopia, é empregada preferencialmente com sêmen congelado. Vários procedimentos cirúrgicos têm sido usados, com a cadela sob anestesia geral e em decúbito dorsal. O sêmen, previamente descongelado, é injetado lentamente no interior do útero e flui facilmente com distensão dos cornos uterinos, dessa forma os espermatozoides são colocados o mais proximo do local da fecundação, uma vez que a viabilidade do sêmen congelado/descongelado é menor. A taxa de gestação descrita na literatura é de 60\% a 100\% (BURGESS et al., 2012; SILVA; VERSTEGEN, 1995; SILVA et al., 1995; SILVA et al., 1996; THOMASSEN et al., 2006).

\section{CONSIDERAÇÕES FINAIS}

A fêmea canina apresenta diversas peculiaridades no que tange à reprodução, como a duração e o perfil hormonal em cada fase do ciclo estral. Tais idiossincrasias refletem nas biotécnicas reprodutivas utilizadas nessa espécie. O estudo da anatomia e fisiologia da reprodução dos cães possibilita o aprimoramento dessas técnicas e adaptação de outras ferramentas avançadas como a manipulação de gametas e embriões in vitro, já bastante difundidas em animais de produção. Dessa forma, contribuindo para a preservação e disseminação de genótipos superiores tanto das raças atuais, quanto de espécies de canídeos selvagens, ameaçados de extinção.

\section{REFERÊNCIAS}

ALHAIDER, A.K.; WATSON, P.F. Cryopreservation of dog semen: the effects of Equex STM paste on plasma membrane fluidity and the control of intracellular free calcium. Animal Reproduction Science, v.110, n.1-2, p.147-161, 2009.

ASA, C.S.; VALDESPINO, C. Canid reproductive biology: An integration of proximate mechanisms and ultimate causes. Am. Zool., v.38, p.251-259, 1998.

AXNÉR, E.; LAGERSON, E. Cryopreservation of dog semen in a tris extender with $1 \%$ or $2 \%$ soya bean lecithin as a replacement of egg yolk. Reproduction in Domestic Animals, v.51, n.2, p.262-268, 2016.

BURGESS, D.E.; MITCHELL, K.E.; THOMAS, P.G.A. Coeliotomy-assisted intrauterine insemination in dogs: a study of 238 inseminations. Australian Veterinary Journal, v.90, p.283-290, 2012. 
CHANDRA, S.A.; ADLER, R.R. Frequency of different estrous stages in purpose-bred beagles: a retrospective study. Toxicol Pathol, v.36, p.944-949, 2008.

CONCANNON, P.W.; HANSEL, W.; VISEK, W.J. The ovarian cycle of the bitch: plasma estrogen, LH and progesterone. Biology of Reproduction, v.13, p.112-121, 1975.

CONCANNON, P.W.; WEIGAND, N.; WILSON, S.; HANSEL, W. Sexual behavior in ovariectomized bitches in response to estrogen and progesterone treatments. Biology Reproduction, v.20, p.799-809, 1979.

CONCANNON, P.W.; WEINSTEIN, P.; WHALEY, S.; FRANK, D. Suppression of luteal function in dogs by luteinizing hormone antiserum and by bromocriptine. Journal of Reproduction and Fertility, v.81, p.175-180, 1987.

CONCANNON, P.W.; MCCANN, J.P.; TEMPLE, M. Biology and endocrinology of ovulation, pregnancy and parturition in the dog. Journal of Reproduction and Fertility, v.39, p.3-25, 1989.

CONCANNON, P.W. Biology of gonadotrophin secretion in adult and prepubertal female dogs. Journal of Reproduction and Fertility, v.47, p.3-27, 1993.

CONCANNON P, TSUTSUI T, SHILLE V. Embryo development, hormonal requirements and maternal responses during canine pregnancy. Journal of Reproduction and Fertility, v.57, p.159-169, 2001.

CONCANNON, P.W. Understanding and Monitoring Canine Pregnancy. Proceedings... World Small Animal Veterinary Association World Congress Department of Biomedical Sciences, Cornell University, Ithaca, NY, USA, 2005.

CONCANNON, P.W. Endocrinologic control of normal canine ovarian function. Reproduction in Domestic Animals, v.44, p.3-15, 2009.

CONCANNON, P.W.; CASTRACANE, V.D.; TEMPLE, M.; MONTANEZ, A. Endocrine control of ovarian function in dogs and other carnivores. Animal Reproduction, v.6, n.1, p.172-193, 2009.

CONCANNON, P.W. Reproductive cycles of the domestic bitch. Animal Reproduction Science, v.124, p.200-210, 2011.

DORE, M.A. Structural aspects of luteal function and regression in the ovary of the domestic dog. Journal of Reproduction and Fertility, v.39, p.41-53, 1989.

DUFFY, D.L.; SERPELL, J.A. Predictive validity of a method for evaluating temperament in young guide and service dogs. Appl. Anim. Behav. Sci., v.138, p.99-109, 2012.

EDQVIST, L.E.; JOHANSSON, E.D.; KASSTRÖM, H.; OLSSON, S.E.; RICHKIND, M. Blood plasma levels of progesterone and oestradiol in the dog during the oestrous cycle and pregnancy. Acta Endocrinology, v.78, n.3, p.554-564, 1975. 
ENGLAND, G.C.W.; RUSSO, M. Breeding management of the bitch. In: BONAGURA, J.D.; TWEDT, D.C. Current Veterinary Therapy XIV. Philadelphia: WB Saunders, p.974979, 2008.

ENGLAND, G.C.W.; RUSSO, M.; FREEMAN, S.L. Follicular Dynamics, Ovulation and Conception Rates in Bitches. Reproduction in Domestic Animals, v.44, n.2, p.53-58, 2009.

FEDERATION CYNOLOGIQUE INTERNATIONALE, 2021. Disponível em: http://www.fci.be/en/. Acesso em maio 2021.

FERNANDES, P.A.; BOWEN, R.A.; KOSTAS, A.C.; SAWYER, H.R.; NETT, T.M.; OLSON, P.N. Luteal function in the bitch: changes during diestrus in pituitary concentration of and the number of luteal receptors for luteinizing hormone and prolactin. Biology Reproduction, v.37, p.804-811, 1987.

FORSBERG, C.L. Biology of reproduction of the dog and modern reproductive technology. In: RUVINSKY, A.; SAMPSON, J. (Eds), The genetics of the dog, Wallingford: CABI Publishing, p.401-432, 2001.

GOBELlO, M.C.; BASCHAR, H.; CASTEX, G.; DE LA SOTA, R.L; GOYA, R.G. Diestrus ovariectomy: an experimental model of canine pseudopregnancy. 4th International Symposium on Canine and Feline Reproduction, Oslo, Norway, Proceedings... p. 20, 2000.

GODDARD, M.E.; BEILHARZ, R.G. Genetic and Environmental Factors Affecting the Suitability of Dogs as Guide Dogs for the Blind. Theor. Appl. Genet., v.62, p.97-102, 1982.

GRAF, K.J. Serum estrogen, progesterone and prolactin concentrations in cyclic, pregnant and lactating beagle dogs. Journal of Reproduction and Fertility, v.52, p.9-14, 1978.

HERNANDES, B.M.S.; LEME, F.C.; PERETTI, R.C.; CAMPLESI, A.C.; MOYA, C.F. Confiabilidade da concentração sérica de progesterona na determinação da taxa de prenhez em cadelas Buldogue Inglês inseminadas com sêmen fresco. In: PEREIRA, A.M.; REIS, S.S.; PEREIRA, W.M.R. (Eds.). Inovação e Pluraridade em Medicina Veterinária 2, cap.13, p.90-98, 2020.

IBGE, Diretoria de Pesquisas, Coordenação de Trabalho e Rendimento. Pesquisa Nacional por Amostra de Domicílios Contínua 2012/2018. Disponível em: https://biblioteca.ibge.gov.br/visualizacao/livros/liv101707_informativo.pdf. Acesso em maio 2021.

IBGE, Pesquisa Nacional em Saúde: Informações sobre domicílios, acesso e utilização dos serviços da $2019 . \quad$ Daúde, Disponível em: https://biblioteca.ibge.gov.br/visualizacao/livros/liv101748.pdf. Acesso em maio 2021.

INSTITUTO PET BRASIL, Censo Pet: 139,3 milhões de animais de estimação no Brasil. Jun, 2019. Disponível em: http:/ /institutopetbrasil.com/imprensa/censo-pet-1393-milhoesde-animais-de-estimacao-no-brasil/. Acesso em maio 2021. 
JEFFCOATE, I.A. Endocrinology of anoestrous bitches. Journal of Reproduction and Fertility, v.47, p.69-76, 1993.

JEFFCOATE, I.A.; LINDSAY, F.E. Ovulation detection and timing of insemination based on hormone concentrations, vaginal cytology and the endoscopic appearance of the vagina in domestic bitches. Journal of Reproduction and Fertility, v.39, p.277-287, 1989.

JOHANNES, J.E. The Basenji annual estrus: Controlled by short-day photoperiod. Basenji, v.39, 12-13, 2003.

JOHNSTON, S.D.; ROOT, M.V. Serum progesterone timing of ovulation in the bitch. Proceedings... Society for Theriogenology. San Antonio. Montgomery, p.195-203, 1995.

KOLER-MATZNICK, J. The origin of the dog revisited. Anthrozoos, v.15, n.2, p.98-118, 2002.

KOWALEWSKI, M.P.; BECERIKLISOY, H.B.; PFARRER, C.; ASLAN, S.; KINDAHL, H.; KUCUKASLAN, I.; et al. Canine placenta: a source of pre-partal prostaglandins during normal and antiprogestin-induced parturition. Reproduction; v.139, p.655-664, 2010.

KOWALEWSKI, M.P.; MICHEL, E.; GRAM, A.; BOOS, A.; GUSCETTI, F.; HOFFMANN, B.; et al. Luteal and placental function in the bitch: spatio-temporal changes in prolactin receptor (PRLr) expression at dioestrus, pregnancy and normal and induced parturition. Reprod Biol Endocrinol, v.9, p.109, 2011.

KUSTRITZ, M.V.R. Managing the reproductive cycle in the bitch. Vet. Clin. Small Anim., v. 42, p.423-437, 2012.

KUTZLER, M.A. Estrous cycle manipulation in dogs. The Veterinary Clinics North America Small Animal Practice, 48, n.4, p.581-594, 2018.

LUVONI, G.C. Current progress on assisted reproduction in dogs and cats: in vitro embryo production. Reprod. Nutr. Dev., v.40, p.505-512, 2000.

LUVONI, G.C.; CHIGIONI, S.; BECCAGLIA, M. Embryo production in dogs: from in vitro fertilization to cloning. Reproduction in Domestic Animals, v.41, n.4, p.286-90, 2006.

MAEJIMA, M.; INOUE-MURAYAMA, M.; TONOSAKI, K.; MATSUURA, N.; KATO, S.; SAITO, Y.; et al. Traits and genotypes may predict the successful training of drug detection dogs. Appl Anim Behav Sci., v.107, p.287-98, 2007.

MANSON, S.J. A retrospective clinical study of endoscopic-assisted transcervical insemination in the bitch with frozen-thawed dog semen. Reproduction in Domestic Animal, v.52, p.275-280, 2017.

MANSON, S.J. Current review of artificial insemination in dogs. Veterinary Clinics Small Animal Practice, v.48, p.567-580, 2018. 
MOGHEISEH, A.; MOSAVI GHIRI, M.J.; BANDARIAN, E. The clinical follow-up of estradiol benzoate priming during induction of estrus with cabergoline in dogs. Topics in Companion Animal Medicine, v.32, n.1, p.16-19, 2017.

MOYA, C.F.; HERNANDES, B.M.S.; LEME, F.C.; CAMPLESI, A.C. Taxa de prenhez e tamanho da ninhada de cadelas Buldogue Inglês inseminadas com sêmen fresco. PUBVET, v.15, n.05, a814, p.1-5, 2021.

OKKENS, A.C.; DIELEMAN, S.J.; BEVERS, M.M.; LUBBERINK, A.A.M.E.; WILLEMSE, A.H. Influence of hypophysectomy on the lifespan of the corpus luteum in the cyclic dog. Journal of Reproduction and Fertility, v.77, p.187-192, 1986.

OKKENS, A.C.; KOOISTRA, H.S. Anoestrus in the dog: a fascinating story. Reproduction in Domestic Animals, v.41, p.291-296, 2006.

OLSON, P.N.; BOWEN, R.A.; BEHRENDT, M.D.; OLSON, J.D.; NETT, T.M. Concentrations of progesterone and luteinizing hormone in the serum of diestrous bitches before and after hysterectomy. Am. J. Vet. Res., v.45, p.149-153, 1984.

OLSON, P.N.; NETT, T.M.; BOWEN, R.A.; et al. Endocrine regulation of the corpus luteum of the bitch as a potential target for altering fertility. Journal of Reproduction and Fertility, v.39, p.27-40, 1989.

ORLAND, B. The invention of artificial fertilization in the eighteenth and nineteenth century. Hist Philos Life Sci., v.39, n.2, p.11, 2017.

PAPA, P. C.; KOWALEWSKI, M. P. Factors affecting the fate of the canine corpus luteum: Potential contributors to pregnancy and non-pregnancy. Theriogenology, v.150, p.339-346, 2020.

PO-YIN, CHU; WRIGHT, P.J.; LEE, C.S. Apoptosis of endometrial cells in the bitch. Reprod. Fertil. Devel., v.14, p. 297-305, 2006.

SCHATTEN, H.; CONSTANTINESCU, G. M. Comparative Reproductive Biology. Hoboken: Blackwell Publishing; 1 ed, 2007.

SICHERLE, C.C.; DE SOUZA, F.F.; FREITAS-DELL'AQUA, C.P.; MOTHÉ, G.B.; PADOVANI, C.R.; PAPA, F.O.; LOPES, M.D. Effects of the cryopreservation process on dog sperm integrity. Animal Reproduction, v.24, n.17, e20190081, 2020.

SILVA, L.D.M.; ONCLIN, K.; SNAPS, F.; VERSTEGEN, J.P. Laparoscopic intrauterine insemination in the bitch. Theriogenology, v.4, p.615-623, 1995.

SILVA, L.D.M.; ONCLIN, K.; LEJEUNE, B.; VERSTEGEN, J.P. Comparisons of intravaginal and intrauterine insemination of bitches with fresh or frozen semen. Veterinary Records, v.138, p.154-157, 1996.

SINGH, B.; MAL, G.; GAUTAM, S.K.; MUKESH, M. Advances in Animal Biotechnology. Berlin: Springer, 2019. 530p. 
SOKOLOWSKI, J.H.; STOVER, D.G.; VAN RAVENSWAAY, F. Seasonal incidence of estrus and interestrus interval for bitches of seven breeds. Journal of the American Veterinary Medical Association, v.171, p.271-273, 1977.

SWENSON, L.; AUDELL, L.; HEDHAMMAR, A. Prevalence and inheritance of and selection for hip dysplasia in seven breeds of dogs in Sweden and benefit: Cost analysis of a screening and control program. Journal of the American Veterinary Medical Association. v.210, p.207-214, 1997.

THOMASSEN, R.; SANSON, G.; KROGENAES. A.; FOUGNER, J.A.; BERG, K.A.; FARSTAD, W. Artificial insemination with frozen semen in dogs: a retrospective study of 10 years using a non-surgical approach. Theriogenology, v.66, n.6-7, p.645-650, 2006.

TSUTSUI, T. Gamete physiology and timing of ovulation and fertilization in dogs. Journal of Reproduction and Fertility, v. 39, p.269-275, 1989.

TSUTSUI, T.; KIRIHARA, N.; HORI, T.; CONCANNON, P.W. Plasma progesterone and prolactin concentrations in overtly pseudo-pregnant bitches: a clinical study. Theriogenology, v.67, p.1032-1038, 2007.

VILÀ, C.; LEONARD, J.A. Origin of dog breed diversity. In: JENSEN, P. (Ed.) The Behavioral Biology of Dogs. Wallingford: CAB International, p.38-58, 2007.

WALTER, B.; OTZDORFF, C.; BRUGGER, N.; BRAUN, J. Estrus induction in Beagle bitches with the GnRH-agonist implant containing $4.7 \mathrm{mg}$ deslorelin. Theriogenology, v.75, n.6, p.1125-9, 2011.

WANG, S. International breeding programs to improve health in pedigree dogs. Tese de doutorado: Swedish University of Agricultural Sciences, 2018.

YAMADA, S., SHIMAZU, Y., KAWAO, Y., NAKAZAWA, M., NAITO, K. AND TOYODA, Y. In vitro maturation and fertilization of preovulatory dog oocytes. Journal of Reproduction and Fertility; v.47, pp. 227-229, 1993. 


\section{INDUÇÃO DE LACTAÇÃO EM NOVILHAS FREEMARTIN- RELATO DE CASO}

\section{José da Páscoa Nascimento Neto}

Centro Universitário de Lavras-UNILAVRAS, Curso de Medicina Veterinária, Lavras, MG Lattes: http://lattes.cnpq.br/3137697725697031

ORCID: https://orcid.org/0000-0002-3185-0513

\section{André Luis Mendes Azevedo Carvalho}

Centro Universitário de Lavras-UNILAVRAS, Curso de Medicina Veterinária, Lavras, MG Lattes: http://lattes.cnpq.br/7775702000946598

\section{Natália Botega Pedroso}

Centro Universitário de Lavras-UNILAVRAS, Curso de Medicina Veterinária, Lavras, MG Lattes: http://lattes.cnpq.br/4235511303228562

\section{Luiz Felipe Rogana Müller}

Centro Universitário de Lavras-UNILAVRAS, Curso de Medicina Veterinária, Lavras, MG Lattes: http://lattes.cnpq.br/1358973696539165

\section{Ana Carolina Chalfun de Sant'Ana}

Universidade Federal de Lavras-UFLA, Departamento de Medicina Veterinária, Lavras, MG Lattes: http://lattes.cnpq.br/0850868705000834

\section{Rilary de Oliveira Mapele}

Centro Universitário de Lavras-UNILAVRAS, Curso de Medicina Veterinária, Lavras, MG Lattes: http://lattes.cnpq.br/2672696463620753

\section{Luthesco Haddad Lima Chalfun}

Centro Universitário de Lavras-UNILAVRAS, Curso de Medicina Veterinária, Lavras, MG Lattes: http://lattes.cnpq.br/4573362053348423

Informações sobre o

artigo:

Recebido em:

23/06/2021

Aceito em:

$30 / 06 / 2021$

Data de publicação:

$19 / 07 / 2021$

Palavras-chave:

Anomalia

Bovino

Freemartinismo

Hormônio

Indução

\section{RESUMO}

Novilhas freemartin são provenientes de gestações gemelares de fetos com sexos opostos e, na maioria dos casos, essa anomalia resulta em infertilidade, e consequentemente ausência lactacional, elevação da taxa de descarte, acarretando em prejuízos econômicos ao proprietário. Uma alternativa ainda pouco estudada, seria a indução de lactação em novilhas que apresentam freemartinismo, por meio da aplicação de hormônios exógenos, onde esses fármacos mimetizam o terço final da gestação bovina. $\mathrm{O}$ método apresenta resultados satisfatórios em vacas que não apresentam nenhum tipo de anormalidade reprodutiva e, pode ser comumente utilizado na rotina de fazendas leiteiras. O objetivo deste trabalho foi relatar a indução de lactação em três novilhas leiteiras freemartin. Após o tratamento hormonal, os animais não apresentaram produção satisfatória em relação a média do rebanho, optando-se pelo descarte das fêmeas. A indução de lactação não apresentou resultados favoráveis neste experimento, porém, são necessários estudos em maior escala para a comprovação da baixa eficácia em animais que apresentam freemartinismo. 


\section{INDUCTION OF LACTATION IN FREEMARTIN HEIFERS- CASE}

REPORT

Freemartin heifers come from twin pregnancies of fetuses with opposite sexes and, in most cases, this anomaly results in infertility, and consequently, lactational absence and drop rate increase, resulting in economic losses to the owner. An alternative, with insufficiently researched, would be the induction of lactation in heifers that present freemartinism, through the application of exogenous hormones, where these drugs mimic the final third of bovine gestation. The method presents satisfactory results in cows that do not present any type of reproductive abnormality and can be commonly used in the routine of dairy farms. The objective of

Keywords:

Anomaly

Bovine

Freemartinism

Hormone

Induction this work was to report the induction of lactation in three freemartin dairy heifers. After hormone treatment, the animals did not present satisfactory production in relation to the herd's average, opting for the culling of the females. The induction of lactation did not show favorable results in this experiment, however, larger scale studies are needed to prove the low efficacy in animals that present freemartinism.

\section{INTRODUÇÃO}

O freemartinismo é uma anomalia do aparelho reprodutor de fêmeas bovinas, que ocorre em gestações gemelares com sexos opostos, em que há troca de células e substâncias plasmáticas, como hormônios entre os fetos (PADULA, 2005). Essa comunicação ocorre por meio de anastomose dos vasos sanguíneos e os fetos passam a apresentar constituição cromossômica quimérica (CONSTABLE et al., 2017). Essa anomalia é geralmente caracterizada por infertilidade e alterações fenotípicas na fêmea. A maioria dos produtores decidem pelo descarte precoce destes animais, a fim de evitar custos relacionados a criação. Uma alternativa para reduzir prejuízos econômicos, seria a indução de lactação através de hormônios exógenos, simulando terço final gestacional de um bovino (OLIVEIRA e FERREIRA, 2016), estimulando o desenvolvimento das glândulas mamárias e a produção de leite (ECCO e BERBER, 2014). O objetivo geral deste trabalho foi relatar a indução de lactação em novilhas leiteiras freemartin.

\section{RELATO DE CASO}

Três fêmeas bovinas, com aproximadamente 20 meses de vida, sendo duas da raça Holandesa, preta e branca (HPB) e uma Girolando (15/16), nulíparas, idade média de 22,5 
meses foram introduzidas em protocolo de indução de lactação com doses reduzidas de hormônios. Esse protocolo com doses reduzidas já havia sido testado em vacas "normais" e apresentou resultado satisfatório. O freemartinismo foi comprovado através de histórico de parto gemelar e, exame ultrassonográfico que detectou ovários ativos e agenesia no corpo do útero ou cérvix. As novilhas eram mantidas em sistema "Free Stall", recebendo ração total misturada (RTM) desde o início do tratamento hormonal com doses reduzidas.

O tratamento foi realizado com: sete aplicações em dias alternados (IM, SID) de 0,005 mg/ kg de PV de benzoato de estradiol, 0,01 mg/kg de PV de cipionato de estradiol e $0,48 \mathrm{mg} / \mathrm{kg}$ de PV de progesterona. Aplicação semanal de 500mg de rbST e após a terceira aplicação, as vacas receberam doses a cada quatorze dias. No dia D15 ao D17, aplicações (IM,SID), $20 \mathrm{mg}$ de dexametasona juntamente com $0,008 \mathrm{mg} / \mathrm{kg}$ de benzoato de estradiol.

No dia D15, 0,53mg de cloprostenol sódico (IM, dose única). A partir do dia D18, os animais foram ordenhados.

\section{RESULTADOS E DISCUSSÃO}

As novilhas foram ordenhadas após 18 dias do início do tratamento hormonal e, por volta de 100 dias em lactação (DEL), apresentaram produção de $4 \pm 2.2 \mathrm{~kg}$ de leite/animal/dia. Produção bem abaixo da expectativa e da média do rebanho, assim, optouse pelo descarte desses animais.

Segundo Freitas et al. (2010), a indução de lactação em vacas sem anormalidade reprodutiva provou ser uma alternativa eficaz, considerando o retorno da produção de leite normal e desempenho reprodutivo dos animais após tratamento hormonal. Contudo, não foram encontrados trabalhos na literatura que expressam resultados na indução de lactação em animais afetados pelo freemartinismo.

\section{CONCLUSÕES}

A indução de lactação com doses hormonais reduzidas, apresentou resposta lactacional satisfatória em outro experimento na mesma propriedade, sendo avaliado em vacas sem anormalidade reprodutiva, obtendo-se produções de leite semelhantes as lactações provenientes de parto natural. Contudo, o mesmo não foi observado em novilhas freemartin, 
demonstrando o insucesso do protocolo nesses animais e necessidade de estudos em maior escala.

\section{REFERÊNCIAS}

CONSTABLE, P. D.; HINCHCLIFF, K. W.; DONE, S. H.; GRÜNBERG, W. Veterinary Medicine: A textbook of the diseases of cattle, horses, sheep, pigs, and goats, eleventh edition. ELSEVIER. 3251 Riverport Lane, St. Louis, Missouri 63043. p.1760. 2017.

ECCO, D.L.M.; BERBER, R.C.A. Indução artificial da lactação em bovinos leiteiros: revisão. Scientific Eletronic Archives, v. 6, p. 67-80, 2014.

FREITAS, P.R.C. et al. Artificial induction lactation in cattle. Revista Brasileira de Zootecnia, v. 39, n. 10, p. 2268-2272, 2010.

OLIVEIRA, M.L.; FERREIRA, C.Y.M.R. Indução da lactação em vacas. Almanaque de Medicina Veterinária e Zootecnia, v. 2, n. 1, p. 1-7, 2016.

PADULA, A. M. The freemartin syndrome: an update. Animal Reproduction Science. Volume 87, Issues 1-2, p. 93-109. 2005. 


\section{CLONAGEM EM BOVINOS: REVISÃO DE LITERATURA}

\section{Lorena Santos Bezerra}

Universidade de Fortaleza, Centro de Ciências da Saúde, Curso de Medicina Veterinária, Fortaleza, CE Lattes: http://lattes.cnpq.br/4384719184797527

ORCID: https://orcid.org/0000-0001-9637-6528

\section{Camila Castelo Trajano}

Universidade de Fortaleza, Centro de Ciências da Saúde, Curso de Medicina Veterinária, Fortaleza, CE Lattes: http://lattes.cnpq.br/2663658854443435

ORCID: https://orcid.org/0000-0002-1967-7842

\section{Jordanna Maria Cassundé Angelino}

Universidade de Fortaleza, Centro de Ciências da Saúde, Curso de Medicina Veterinária, Fortaleza, CE Lattes: http:/ / lattes.cnpq.br/6916986099758012

ORCID: https://orcid.org/0000-0002-2799-1081

\section{Thaís Maria Araújo Batista}

Universidade de Fortaleza, Centro de Ciências da Saúde, Curso de Medicina Veterinária, Fortaleza, CE Lattes: http://lattes.cnpq.br/5888728967616427

ORCID: https://orcid.org/0000-0003-2243-0813

\section{Mateus Nunes Diógenes}

Universidade de Fortaleza, Centro de Ciências da Saúde, Curso de Medicina Veterinária, Fortaleza, CE Lattes: http://lattes.cnpq.br/9227353232716491

ORCID: https://orcid.org/0000-0002-1276-0379

\section{Roberta Nogueira Chaves}

Universidade de Fortaleza, Centro de Ciências da Saúde, Curso de Medicina Veterinária, Fortaleza, CE Lattes: http://lattes.cnpq.br/8935178404351592

ORCID: https://orcid.org/0000-0002-5367-0724

Informações sobre o

artigo:

\section{Recebido em:}

$03 / 05 / 2021$

Aceito em:

$08 / 05 / 2021$

Data de publicação:

$19 / 07 / 2021$

Palavras-chave:

Biotecnologia

Bovinos

Células somáticas

Clonagem animal

\section{RESUMO}

A clonagem animal representa um dos maiores avanços obtidos até hoje no campo da biotecnologia animal e apresenta inúmeras aplicações científicas e comerciais, incluindo a multiplicação de animais de excelência, a produção de animais transgênicos, ou mesmo a produção de células para fins biomedicinais. Desde o nascimento da ovelha Dolly, grupos de pesquisas têm empregado a técnica de transferência nuclear de células somática (TNCS) para a produção de embriões em diferentes espécies, principalmente em bovinos. Em geral, a transferência nuclear consiste em transferir núcleos de células doadoras para o interior de oócitos enucleados, resultando em indivíduos geneticamente idênticos ao animal doador do núcleo. Contudo, a eficiência da técnica ainda é considerada baixa, com menos de $5 \%$ dos embriões clones produzidos resultando em animais nascidos vivos. O sucesso na clonagem exige o exímio domínio técnico e científico de complexos fenômenos moleculares fisiológicos e embrionários que sofrem influência de fatores intrínsecos e extrínsecos, interagindo 
entre si. Desta forma, o objetivo desse trabalho é realizar uma revisão de literatura acerca do tema da clonagem em bovinos, abordando os aspectos históricos da clonagem no Brasil e no mundo, destacando a TNCS, bem como suas etapas e os principais fatores que interferem no seu sucesso.

\section{CATTLE CLONING: LITERATURE REVIEW}

Animal cloning represents one of the greatest advances made to date in the field of animal biotechnology and has numerous scientific and commercial applications, including the multiplication of excellent animals, the production of transgenic animals, or even the production of cells for biomedical purposes. Since the birth of Dolly the sheep, research groups have used the somatic cell nuclear transfer technique (TNCS) for the production of embryos in different species, mainly in cattle. In general, nuclear transfer consists of transferring donor cell nuclei into enucleated oocytes, resulting in individuals genetically identical to the nucleus donor animal. However, the efficiency of the technique is still considered low, with less than $5 \%$ of the clone embryos produced resulting in animals born alive. Success in cloning requires the expert technical and scientific mastery of complex physiological and embryonic molecular phenomena that are influenced by intrinsic and extrinsic factors, interacting with each other. Thus, the objective of this work is to carry out a literature review on the topic of cloning in cattle, addressing the historical aspects of cloning in Brazil and in the world, highlighting TNCS, as well as its stages and the main factors that interfere with its success.

\section{INTRODUÇÃO}

Conceituadamente, define-se clone como um grupo de moléculas, células e organismos que derivam de uma única molécula ou célula, e que a partir dela, tornam-se igual à célula que a originou e idênticas entre si (TRECENTI e ZAPPA, 2013).

Em virtude do avanço das técnicas de biotecnologia da reprodução, atualmente tornou-se possível a geração de clones ou cópias idênticas de indivíduos, o que contribui diretamente para a evolução da produção animal, por meio do melhoramento genético dos rebanhos mundo afora (THIBIER, 2005).

Além disso, a criação de clones representa, ainda, um ambiente fértil para a ciência e para a pesquisa, e convertem-se em benefícios práticos em inúmeros setores, como o de descobertas e produção de proteínas recombinantes que possuem grande utilidade na saúde humana (BERTOLINI et al., 2012). 
As aplicações da clonagem não se restringem apenas àquelas direcionadas a fins zootécnicos e de produção animal, mas incluem outras aplicabilidades significamente promissoras, como a utilização na preservação de espécies ameaçadas de extinção, na criação de animais transgênicos, e na geração de células ou tecidos para fins medicinais (OBACK e WELLS, 2003).

Historicamente, a prática da clonagem teve início no século XX, como forma de investigar os mecanismos envolvidos na diferenciação celular, e foi inaugurada por Hans Spemann, biólogo que realizou experimentos com embriões de salamandras. Porém, apenas no ano de 1951, a primeira clonagem propriamente dita foi realizada. O feito foi atribuído a pesquisadores da Filadélfia, que realizaram o primeiro transplante de núcleos a partir de células embrionárias de rãs (MELLO, 2003).

A partir daí, inúmeros experimentos foram realizados, inclusive com mamíferos, e entre sucessos e insucessos, no ano de 1986, obteve-se o nascimento de 3 cordeiros clones, na Dinamarca. No Brasil, porém, apenas em 2001, em Brasília, é que nasceu o primeiro clone bovino a partir de célula embrionária.

Diante disso, no presente trabalho serão abordados aspectos relevantes relacionados à temática da clonagem bovina, com o objetivo de fazer uma revisão de literatura acerca do tema.

\section{REFERENCIAL TEÓRICO}

\subsection{Breve histórico da clonagem de bovinos no Brasil e principais desafios}

Nos anos 90, mais precisamente em 1996, veio ao mundo a ovelha clonada Dolly, na Escócia. Dolly foi o primeiro animal a ser clonado com sucesso por transferência nuclear a partir de uma célula somática diferenciada obtida de um animal adulto, e não de células embrionárias de poucos dias de desenvolvimento, como o que era feito até então (CAMPBELL et al., 2005).

Este fato abriu portas para uma infinidade de estudos nos centros de pesquisa ao redor do mundo, e provocou uma revolução na ciência contemporânea. Anos depois, no Brasil, o país entraria no cenário da clonagem, com o nascimento de Vitória, da Embrapa, o primeiro clone bovino a partir de uma célula embrionária.

A partir daí, vários pesquisadores, além dos brasileiros, procuraram reproduzir as experiências de sucesso na clonagem, não apenas na espécie bovina, que é a que melhor se 
adapta à técnica, mas também em caprinos, ovinos e equinos (VISINTIN et al., 2008). Entretanto, mesmo nos dias de hoje, onde as biotecnologias de reprodução tanto avançaram e os estudos sobre clonagem animal encontram-se em outro patamar de evolução, ainda existem muitos desafios a serem superados e diversas dúvidas a serem esclarecidas, principalmente no que diz respeito à viabilidade fetal e neonatal destes clones, levando em consideração as altas taxas de mortalidade registradas nesse período, bem como a grande incidência de anomalias sobre os animais gerados (PANARACE et al., 2007).

Sem dúvidas, um dos maiores desafios relacionados à clonagem de bovinos está relacionada à manutenção da sanidade das crias nascidas e ao entendimento dos processos patológicos que estão envolvidos nestas perdas, tendo em vista que representam um grande prejuízo econômico, pois são resultado de um grande investimento financeiro e científico (ALVAREZ, 2008).

Dentre as principais anomalias observadas em neonatos bovinos provenientes de técnica de clonagem, estão: cardiopatias, placentação anormal, hidroalantóide, deficiência imunológica, disfunção renal, alterações no metabolismo energético e hipertensão pulmonar (LANZA, 2001).

\subsection{Técnicas de clonagem em bovinos}

A clonagem pode possuir duas finalidades, a clonagem com fim reprodutivo e a clonagem com fim terapêutico. Na clonagem reprodutiva, tem-se por objetivo produzir um animal geneticamente igual ao seu progenitor. Sob uma perspectiva zootécnica, esta é uma prática que visa o melhoramento genético dos rebanhos, através da seleção de animais geneticamente superiores, afim de transmitir uma característica específica considerada vantajosa que aumente a produtividade do rebanho e produza animais com perfil de excelência (MIGLINO, 2004). Já a clonagem com finalidade terapêutica, tem por objetivo a produção de tecidos ou órgãos, no intuito de utilizá-los na esfera da bioengenharia tecidual ou na medicina regenerativa (POLEJAEVA et al., 2000).

As técnicas de clonagem, dentre tantas aplicações, recebem destaque pela sua capacidade de promover a conservação e a regeneração dos recursos genéticos e contribuírem para uma maior compreensão acerca dos processos de interação entre núcleo e citoplasma (VARAGO et al., 2008). Os métodos de clonagem conhecidos são: a partição de embriões pré-implantacionais (fissão), a paraclonagem, e a clonagem "verdadeira", explicada a seguir. 
A técnica de clonagem "verdadeira" consiste na transferência de núcleos de células de animais já nascidos a oócitos enucleados, dando origem a animais fenotipicamente praticamente iguais e quase idênticos ao doador do núcleo, diferenciando-se apenas geneticamente por mutações somáticas e pelo genoma mitocondrial do oócito (GALLI et al., 2003).

Dentre os diferentes métodos de clonagem mencionados anteriormente, recebe destaque na comunidade científica esta última, a técnica de Transferência Nuclear (TN) através da utilização de células somáticas. A clonagem de embriões bovinos a partir de células somáticas representa atualmente a única técnica de biotecnologia reprodutiva possível de assegurar que o animal originado é capaz de preservar 100\% do material genético do seu progenitor, isso por quê nesta técnica, a etapa de "crossing over (troca de material genético) não ocorre. Esse diferencial faz dela o método mais benquisto entre os pesquisadores, principalmente para reproduzir animais transgênicos previamente "desenhados", com o objetivo, por exemplo, de produzir uma determinada proteína recombinante para aplicabilidade na saúde pública (CAMPBELL, 2007).

\subsection{Transferência nuclear de células somáticas}

A clonagem pode ser feita utilizando-se células de origens distintas, células embrionárias ou células somáticas (FAIRBURN et al., 2002).

Todo o processo se inicia no momento da fecundação, ou seja, quando um espermatozoide e um óvulo se unem dando origem a uma célula 2n. Esta célula, por sua vez, divide-se em duas outras células, que darão origem a quatro células, e posteriormente em oito e assim por diante. Até este momento cada uma destas células possui o poder de desenvolver um ser completo e, por esse motivo, são denominadas de células tronco totipotentes. Quando chegam à fase de 8 ou 16 células, as células do embrião se diferenciam em dois grupos distintos: um grupo de células externas que serão responsáveis pelo desenvolvimento da placenta e dos anexos embrionários, e um segundo grupo, uma massa de células internas que vão dar origem ao embrião propriamente dito. Quando chegam à fase de 100 células, este conjunto de células do embrião recebe o nome de blastocisto, e então nesta fase ocorre a implantação do embrião na cavidade uterina. Em seguida, as células da massa interna do blastocisto darão origem aos diferentes tecidos que compõem o organismo, e devido a sua 
capacidade de diferenciação, são denominadas de células-tronco embrionárias pluripotentes (GALLI et al., 2003).

As células somáticas, por serem células que já sofreram diferenciação, não possuem mais a capacidade de dar origem a qualquer tecido ou órgão.

As células embrionárias, por sua vez, podem ser produzidas e cultivadas in vitro, em laboratório, e são passíveis de serem manipuladas, de modo que são suscetíveis a adições ("knock in") e deleções seletivas ("knock out”) de genes no genoma de animais de produção, e com isso propiciar a produção de uma serie de proteínas terapêuticas, comportando-se como "biorreatores" (SILVA, 2004).

A clonagem de animais pela técnica de transferência nuclear abrange múltiplas etapas: (1) seleção dos oócitos receptores; (2) preparo dos oócitos receptores: maturação e enucleação; (3) obtenção e maturação das células doadoras de núcleos; (4) reconstrução e ativação dos oócitos receptores e (5) cultivo e transferência de embriões reconstituídos para fêmeas receptoras (FULKA et al., 1998), cada uma dessas fases podendo influenciar diretamente no resultado final, sendo abordadas mais detalhadamente a seguir.

\subsection{Seleção e preparo dos oócitos receptores}

Os oócitos receptores ou citoplasma receptor (citoplasto) são obtidos através da aspiração de ovários, procedentes de abatedouros ou de fêmeas pré-selecionadas utilizandose a técnica de aspiração folicular com auxilio de ultrassonografia (RIDEOUT et al., 2001).

Diversos estudos já foram realizados buscando identificar a fase ideal do citoplasto para ser considerado adequado para a utilização nos protocolos de clonagem, e a partir disso, considerou-se que os oócitos em estágio de metáfase II (MII) são os mais adequados, quando comparados aos demais estágios, para suportar a reprogramação nuclear (MARTINEZ, 2007). As três principais fases relacionadas aos oócitos receptores em um programa de clonagem por transferência nuclear de células somáticas são: maturação, enucleação e ativação (PRATHER e FIRST, 1990).

\subsection{Maturação e enucleação}

A maturação dos oócitos consiste em amadurecê-los e conduzi-los até uma determinada fase meiótica, a fase de metáfase II, ou estágio de segunda divisão meiótica. 
Quanto às formas de maturação, admite-se que esta pode ser feita nas modalidades in vivo ou in vitro (GURDON e COLMAN, 1999).

Na maturação in vivo, os oócitos são normalmente recuperados dos ovidutos após a ovulação ou podem ser recuperados diretamente dos folículos no momento que antecede a ovulação. Já na maturação in vitro, que é a mais utilizada em bovinos por apresentar uma série de vantagens como o baixo custo, os oócitos que se encontram no estágio de prófase I ou vesícula germinativa, são recuperados de folículos antrais e posteriormente atingem a fase de metáfase II (ZOU et al., 2001).

Para realizar a maturação de oócitos, utilizam-se meios equivalentes àqueles empregados para a produção in vitro de embriões (PIV), ou seja, meio TCM 199 acrescido de hormônios e antibióticos, conservados em temperatura de 38,5 a 39, $0^{\circ}$ durante 16 a 24 horas, em atmosfera com umidade saturada contendo 5\% de CO2 em ar (WELLS, 2005).

O uso de suplementos como o estradiol, o fator de crescimento semelhante a insulina (IGF-I), e a cisteamina, em meios de maturação, tem sido frequentemente realizado nas rotinas de clonagem por transferência nuclear, porém não há evidências científicas de que esses fatores exerçam influência positivas na maturação de oócitos, não tendo sido evidenciado nenhuma diferença na produção de animais saudáveis (PRATHER et al., 1987).

O principal fator determinante na escolha do método de maturação é feito de acordo com qual espécie se deseja reproduzir. Como por exemplo, nos casos de clonagem de animais de laboratório, opta- se pela maturação in vivo, visto que a recuperação dos oócitos é feita após a eutanásia dos animais. Em contrapartida, nos casos de bovinos, usualmente prefere-se o uso do método de maturação in vitro, pois possibilita um maior controle dos estágios de maturação, o que contradiz alguns estudos que relatam que os oócitos maturatos in vivo adquiriam maior potencial para suportar seu desenvolvimento (FULKA et al., 1998).

Para utilizar oócitos como citoplastos receptores na técnica de transferência nuclear, é necessário realizar, além da maturação dos oócitos, o procedimento de enucleação, que consiste na remoção do material nuclear (cromossomos) do citoplasma receptor, restando apenas seu conteúdo citoplasmático (KEEFER et al., 2002).

Para preparar os oócitos para o procedimento de enucleação, é necessário promover a retirada das células do cúmulus oophorus, e em seguida proceder a uma rigorosa inspeção dos oócitos com o objetivo de verificar as condições do citoplasma e a presença de 
um corpúsculo polar. Feito isto, submete-os à exposição de substâncias desestabilizadoras de seu citoesqueleto, como a fitohemaglutinina (MOGOLLÓN-WALTERO et al., 2014).

Basicamente, a técnica de enucleação é realizada com oócitos em estágio de metáfase II (M-II) e baseia-se na microaspiração do primeiro corpúsculo polar (CP), juntamente da aspiração da placa metafásica de oócitos, com o auxílio de micropipetas acopladas a micromanipuladores (DINNYÉS et al., 2002).

Quando esta técnica é realizada sem a utilização de micromanipuladores, ela é chamada de enucleação manual ou handmade cloning (HMC), a qual vem sendo cada vez mais utilizada em laboratórios visando simplificar os protocolos experimentais e promover a redução de custos (MEIRELLES et al., 2009). O princípio básico desta técnica consiste em induzir os eventos necessários da enucleação à semelhança dos métodos tradicionais, porém substituindo o uso de micromanipuladores por microlâminas que permitem a enucleação manual (JAENISCH et al., 2002).

\subsection{Obtenção e maturação das células doadoras de núcleos}

A fonte e a qualidade dos núcleos doadores utilizados para transferência nuclear representam fatores determinantes para a capacidade de desenvolvimento dos embriões reconstruídos, influenciando fortemente no seu desenvolvimento fetal pós implantação e, consequentemente contribuindo para o sucesso da clonagem em bovinos (CHAVATTEPALMER et al., 2002). A partir do nascimento do primeiro mamífero clone originado de células embrionárias em cultivo e de linhagens fetais e adultas, inúmeros centros de pesquisa dedicaram-se a investigar os mecanismos celulares envolvidos neste processo e evidenciaram que células somáticas de idades e tecidos distintos podem ser utilizadas com êxito nos protocolos de transferência nuclear (LEE et al., 2007). Sabe-se atualmente que diferentes tipos de células doadoras podem ser reprogramadas. Entretanto, o uso de fibroblastos obtidos de biópsias de feto ou de animais adultos, da pele ou do músculo, consagrou-se ao longo do tempo como o modelo celular de eleição na maioria dos programas de clonagem (CIBELLI et al., 2002).

Dentre os tipos de tecido que podem ser utilizados como doadores de núcleo, incluem-se as células epiteliais de glândula mamária, as células do cumulus, células oviductais, células da granulosa, do fígado, do útero, músculo, linfócitos e fibroblastos, demonstrando com isso uma grande variabilidade de opções (BATCHELDER et al., 2005). 
Em relação à utilização das células doadoras de núcleo, alguns autores indicam a sua aplicação diretamente após a sua coleta do animal doador (Bertolini e Bertolini, 2009), enquanto outros preconizam que a utilização destas células só deve ser feita após um período de cultivo, antes ou depois da criopreservação (LANZA, 2001).

O protocolo convencional para obtenção dos tecidos com células doadoras de núcleo de bovinos, consiste na retirada do tecido mediante a realização de biópsia em condições assépticas. Alguns autores relatam preferência pela região da orelha para retirada do fragmento. A partir daí esse tecido deve ser conservado em baixas temperaturas e deve ser transportado em condições de refrigeração, de preferência mantidos em tubos contendo meios com soro fetal bovino e sulfato de gentamicina (FAIRBURN et al., 2002). Posteriormente, em laboratório, os tecidos são clivados em pequenas seções medindo aproximadamente $1 \mathrm{~mm}$, e em seguida são acondicionados em placas de Petri até a altura de sua aderência ao fundo, e então são cobertos com meio de cultivo enriquecido com soro fetal. Finalmente, são submetidos ao cultivo em incubadoras a $39^{\circ} \mathrm{C}$ e atmosfera de $5 \% \mathrm{CO} 2$, durante 7 a 14 dias (VAJTA et al., 2003).

Os carioplastos provindos das amostras de células doadoras de núcleos podem ser cultivados em meio Dulbecco enriquecidos com $10 \%$ de soro fisiológico bovino (SFB) em temperatura de $38,5^{\circ} \mathrm{C}$ acrescidos de 5\% de CO2 (CAMPBELL et al., 2007). Após 15 dias, os fibroblastos devem ser tripsinizados e cultivados em uma nova placa, o que resultará na passagem 1. Uma vez atingida a confluência desejada, estas células podem ser ressemeadas em outras placas, e só podem ser utilizadas para transferência nuclear após três ou quatro passagens. Essas células são mantidas em confluência ou cultivadas em meio suplementado com $0,5 \%$ de soro, com o objetivo de aumentar a proporção de células em G0 e G1. Em cerca de 30 minutos antes da transferência nuclear, estas células são preparadas por tripsinização, sendo as mesmas lavadas em meio Synthetic Oviductal Fluid (SOF) tamponado com HEPES [N-(2-hydroxyethyl)- piperazine-N'-(2-ethanesulphonic acid)] (PEREIRA e FREITAS, 2009).

\subsection{Reconstrução e ativação dos oócitos receptores}

A reconstrução dos embriões consiste em uma das etapas chave da técnica de transferência nuclear e pode ser realizada por diferentes métodos, onde os principais são a microinjeção e a fusão entre as membranas plasmáticas da célula doadora e do oócito 
receptor. A fusão celular pode ser promovida por diferentes técnicas, sendo as mais importantes a eletrofusão ou eletroporação, que é um método baseado na utilização de impulsos elétricos; o uso de lipossomos, que são vesículas lipídicas, a aplicação de poetilenoglicol, e por último, o vírus Senai inativo. Dentre os métodos citados anteriormente, o de eletrofusão é o mais recomendado pelos autores para a maioria das espécies (TRECENTI e ZAPPA, 2013).

O procedimento padrão de reconstrução dos embriões após a transferência nuclear consiste na transferência do núcleo celular doador (carioplasto) para o interior de um citoplasma receptor (citoplasto). Desse modo, cada célula doadora que foi isolada individualmente após o cultivo prévio é introduzida no espaço perivitelino de um oócito enucleado. Em seguida, deve ser realizado uma estimulação com um pulso elétrico, o que resultará na fusão da célula somática com o oócito enucleado, formando um novo complexo. Além disso, esse impulso elétrico é capaz de promover uma significativa liberação de cálcio intracelular que dará início à próxima etapa do processo, a ativação, considerada por muitos autores como a etapa que necessita de mais aperfeiçoamento no procedimento da transferência nuclear e que será discutida mais adiante (ROBL, 1999).

Como mencionado anteriormente, o método de eletrofusão é o mais utilizado atualmente para a reconstrução de embriões em ruminantes, possuindo parâmetros de duração, intensidade e número de pulsos variáveis a depender da espécie em questão, do tipo de equipamento utilizado e do tipo de célula a ser fundida (GALLI et al., 2003). A modalidade de eletrofusão possui pulsos de 2 correntes, a alternada e a direta. A corrente alternada é aplicada para posicionar as membranas a serem fundidas paralelamente aos eletrodos, e é aplicada com uma frequência de 600 a $1000 \mathrm{kHz}$, voltagem de 5 a $6 \mathrm{~V}$ durante 5 a $10 \mu \mathrm{s}$ (microssegundos). Já a corrente direta, tem a função de promover a formação dos poros nas membranas, o que leva a fusão entre as células e é aplicada em três pulsos com intensidade de 0,6 a 3,6 kV/cm com duração de 30 a 250 us (CHAVATTE-PALMER et al., 2004).

Após a etapa de fusão, os embriões reconstruídos por transferência nuclear são submetidos à ativação artificial, a qual tem o objetivo de mimetizar o papel exercido pelos espermatozoides durante a fecundação (BERTOLINI et al., 2012).

Os eventos inerentes à ativação oocitária são o início das oscilações intracelulares de cálcio, a exocitose de grânulos corticais, o recrutamento de mRNAs, a formação dos prónúcleos e o início da síntese de DNA (VISINTIN et al., 2008).

A ativação dos oócitos pode ser obtida através de métodos físicos ou químicos, por técnicas que podem ou não estar diretamente ligadas aos níveis de cálcio intracelular. Dentre 
os métodos físicos, o mais utilizado é a a injeção de cálcio diretamente no citoplasma, promovendo em seguida estímulos elétricos que promoverão a liberação de concentrações intracelulares de cálcio (THIBIER, 2005).

Quanto aos meios químicos, podem ser citados a exposição ao ionóforo de cálcio A23187, que promove a entrada de $\mathrm{Ca}+2$ extracelular, o uso de iomicina, ciclohexamida e puromicina, etanol, 6- Dimetilaminopurina (6-DMAP), e o estrôncio (LEE et al. 2007).

\subsection{Cultivo e transferência de embriões reconstituídos para fêmeas receptoras}

Feitas as etapas de fusão e ativação, os embriões serão cultivados in vitro, e para isso, diversos tipos de sistemas de cultivo enriquecidos com suplementos são rotineiramente utilizados. Dentre estes componentes, os mais comumente utilizados são: soro fetal bovino, soro de cabra/ovelha em estro, albumina sérica bovina (BSA), fatores de crescimentos e vitaminas, entre outros (VARAGO et al., 2008).

Estudos envolvendo a transferência nuclear na espécie bovina, verificaram que embriões cultivados em soro fetal bovino sem cocultivo, submetidos atmosfera de três gases ( $5 \%$ de $\mathrm{O} 2,5 \%$ de $\mathrm{CO} 2,90 \%$ de N2), apresentaram melhores taxas de clivagem e formação de blastocistos quando comparados àqueles tratados em sistemas de cocultivo (KRUIP, 1997).

Em bovinos, o procedimento de transferência de embriões pode ser feito de modo cirúrgico, semi-cirúrgico ou não cirúrgico. O método cirúrgico ou laparotomia consiste em exteriorizar o corno uterino e depositar os embriões próximos à junção útero-tubárica (WILSON et al., 1995). A técnica semi-cirúrgica também pode ser chamada de semilaparoscópica e é pouco utilizada em bovinos, sendo mais aplicada em caprinos e ovinos. Basicamente, esse método associa a laparoscopia a uma pequena incisão cirúrgica dispensando a necessidade do uso de anestesia geral. Finalmente, o método não cirúrgico é bastante empregado em bovinos e consiste em depositar os embriões, por via transcervical, no corno uterino ipsilateral ao ovário, que apresente no mínimo um corpo lúteo (OGONUKI, 2002).

A etapa de transferência do embrião é consideravelmente sensível a interferências de fatores extrínsecos e ambientes, dentre eles a necessidade de expertise e entendimento dos processos biológicos e reprodutivos que envolvem os critérios de seleção de fêmeas receptoras, o manejo dos ciclos estrais, e de habilidades técnicas específicas, como a 
transferência de embrião (TE) propriamente dita, que é rotineiramente realizada no sétimo dia de desenvolvimento, após cultivo in vitro (CIV) dos embriões, de acordo com os protocolos convencionais de clonagem (TIAN et al., 2003). Entretanto, uma vez controlados os fatores técnico-biológicos anteriormente mencionados, o sucesso desta fase passa a depender exclusivamente de aspectos intrínsecos aos embriões clonados, relacionados à viabilidade dos embriões transferidos (KATO, 1998).

\subsection{Fatores que afetam o sucesso da técnica de transferência nuclear}

Embora a técnica de clonagem tenha se difundido globalmente e diversos animais clones de diferentes espécies tenham sido produzidos a partir de células somáticas em diversos laboratórios pelo mundo, a eficiência da técnica ainda é considerada baixa devido a interferência de inúmeros fatores. Além disso, são observadas amplas variações nos resultados, apesar do uso das mesmas condições de clonagem, que inclui os tipos de células, os protocolos de ativação e as práticas de cultivo dos embriões. Essas intercorrências provém de diversos fatores adversos que impactam na qualidade e na viabilidade dos embriões produzidos por transferência nuclear, desde o estágio de pré-implantação até o desenvolvimento pós-natal dos animais clonados. Dentre estes fatores, destacam-se principalmente aqueles relacionados às falhas na reprogramação epigenética, especialmente o imprinting genômico (MEIRELLES et al., 2009).

A reprogramação epigenética é um evento fundamental para descartar alterações epigenéticas adquiridas, prevenindo assim, sua transmissibilidade para a geração descendente (KATO et al., 1998). A reprogramação epigenética acontece quando o modelo de expressão de uma célula diferenciada é anulado e o novo padrão de expressão gênica embrionária é definido, no intuito de conduzir o desenvolvimento embrionário e fetal. Para tal, o núcleo transferido deve anular os genes associados à diferenciação, que foram transcritos na célula doadora original. Dessa forma, considera-se que uma reprogramação inapropriada no núcleo após a TN resultará em uma falha no desenvolvimento dos clones (CIBELLI et al., 2002).

Assim, infere-se que o processo de reprogramação epigenética é o ponto-chave capaz de determinar alterações de expressão gênica que se manifestam consecutivamente, e que dependendo do seu grau, ditam a intensidade dos problemas subsequentes, em um "efeito dominó", resultando em mudanças morfo-fisiológico-metabólicas com efeitos preponderantes na placenta, iniciadas na fase embrionária e perpetuadas e intensificadas na fase fetal e após o nascimento. Constatou-se que o nível de expressividade de determinada 
falha no início da gestação, é capaz de repercutir em menor ou maior grau em todas as etapas subsequentes, induzindo mudanças na programação metabólica pré-natal, a qual poderá afetar a função placentária, que por sua vez provocará efeitos no crescimento do concepto, levando a mudanças indesejadas no periparto, e consequentemente, comprometendo a sobrevivência até a fase adulta, como uma cascata de eventos (MIGLINO, 2004).

Hill et al. (2001) destaca a importância da fonte de células doadora de núcleo como fator capaz de influenciar na baixa eficiência da TN, uma vez que quanto menor o grau de diferenciação de uma célula, mais potencialmente ela será desprogramada pelo citoplasma receptor, o que acarretará distúrbios futuros. Alguns autores atribuem algumas disfunções no processo de clonagem ao cultivo prolongado das células doadoras, pois ele pode alterar a ploidia, estabilidade genômica e provocar modificações nas histonas pós- tradução (OGONUKI et al., 2002).

\section{CONSIDERAÇÕES FINAIS}

Diante do exposto, conclui-se que a produção de bovinos clones é um processo complexo que compreende uma série de etapas minuciosas e bastante delicadas, e que envolve uma combinação de fatores tanto biológicos como técnicos que interagem entre si. Atualmente, a clonagem animal apresenta-se como uma biotecnologia de reprodução de extrema importância econômica, e que tem gerado um forte interesse dos setores científicos e produtivos. No Brasil, a clonagem de bovinos já é uma realidade, multiplicando animais de excelência que detém características geneticamente valorizadas e contribuindo para o melhoramento genético de rebanhos.

Nesta temática, a técnica de clonagem por transferência nuclear de células somáticas se mostra como a melhor opção e é o método mais utilizado para a clonagem de animais tanto para fins zootécnicos quanto terapêuticos.

Desta maneira, pesquisas ainda necessitam ser realizadas para que melhores resultados sejam obtidos no processo de clonagem. A maior parte desses estudos deve ser direcionada principalmente no intuito de compreender os diversos mecanismos moleculares envolvidos que podem comprometer o desenvolvimento dos animais e integrar alternativas que visem simplificar os protocolos experimentais e reduzir os custos relacionados à técnica. 


\section{REFERÊNCIAS}

ALVAREZ, R. H. Fatores determinantes do sucesso de um programa de transferência de embriões em bovinos. In: Infobibos informações tecnológicas. 2008.

BATCHELDER, C. A. et al. Effect of the nuclear-donor cell lineage, type, and cell donor on development of somatic cell nuclear transfer embryos in cattle. Cloning and stem cells, v. 7, n. 4, p. 238-254, 2005.

BERTOLINI, M.; BERTOLINI, L. R. Advances in reproductive technologies in cattle: from artificial insemination to cloning. Revista de la Facultad de Medicina Veterinaria y de Zootecnia, v. 56, n. 3, p. 184-194, 2009.

BERTOLONI, L. $\mathrm{R}$ et al. Clonagem animal: a sobrevivência dos mais aptos. Revista Ciência Animal, n. 22, v. 1, p. 82-105, 2012.

CAMPBELL, K. H. S. et al. Cloning: eight years after Dolly. Reproduction in Domestic Animals, v. 40, n. 4, p. 256-268, 2005.

CAMPBELL, K. H. S. et al. Somatic cell nuclear transfer: past, present and future perspectives. Theriogenology, v. 68, p. S214-S231, 2007.

CIBELLI, J. B. et al. The health profile of cloned animals. Nature biotechnology, v. 20, n. 1, p. 13-14, 2002.

CHAVATTE-PALMER, P. et al. Clinical, hormonal, and hematologic characteristics of bovine calves derived from nuclei from somatic cells. Biology of reproduction, v. 66, n. 6, p. 1596-1603, 2002.

CHAVATTE-PALMER, P. et al. Health status of cloned cattle at different ages. Cloning \& stem Cells, v. 6, n. 2, p. 94-100, 2004.

DINNYÉS, A. et al. Somatic cell nuclear transfer: recent progress and challenges. Cloning \& Stem Cells, v. 4, n. 1, p. 81-90, 2002.

FAIRBURN, H. R.; YOUNG, L. E.; HENDRICH, B. D. Epigenetic reprogramming: how now, cloned cow?. Current biology, v. 12, n. 2, p. R68-R70, 2002.

FULKA, J. R. J. et al. Cloning by somatic cell nuclear transfer. Bioessays, v. 20, n. 10, p. 847-851, 1998.

GALLI, C.; LAGUTINA, I.; LAZZARI, G. Introduction to cloning by nuclear transplantation. Cloning \& Stem Cells, v. 5, n. 4, p. 223-232, 2003.

GURDON, J. B.; COLMAN, A. The future of cloning. Nature, v. 402, n. 6763, p. 743-746, 1999.

HEYMAN, Y.; RENARD, J. P. Cloning of domestic species. Animal Reproduction Science, v. 42, n.1-4, p. 427- 436, 1996. 
HILL, J. R et al. Bovine nuclear transfer embryo development using cells derived from a cloned fetus. Animal reproduction science, v. 67, n. 1-2, p. 17-26, 2001.

JAENISCH, R. et al. Nuclear cloning, stem cells, and genomic reprogramming. Cloning $\boldsymbol{\&}$ Stem Cells, v. 4, n. 4, p. 389-396, 2002.

KATO, Y. et al. Eight calves cloned from somatic cells of a single adult. Science, v. 282, n. 5396, p. 2095- 2098, 1998.

KEEFER, C. L. et al. Production of cloned goats after nuclear transfer using adult somatic cells. Biology of reproduction, v. 66, n. 1, p. 199-203, 2002.

KRUIP, TH. AM.; DEN DAAS, J. H. G. In vitro produced and cloned embryos: effects on pregnancy, parturition and offspring. Theriogenology, v. 47, n. 1, p. 43-52, 1997.

LANZA, R. P et al. Cloned cattle can be healthy and normal. Science, v. 294, n. 5548, p. 1893-1894, 2001.

LEE, S. L. et al. Cellular composition and viability of cloned bovine embryos using exogenetransfected somatic cells. Reproduction in domestic animals, v. 42, n. 1, p. 44-52, 2007.

MARTINEZ, D. M. A. et al. Gestaciones producidas con embriones bovinos clonados por transferencia nuclear. Archivos de medicina veterinaria, Valdivia, v. 39, n. 1, p. 59-62, 2007.

MEIRELLES, F. V. et al. Delivery of cloned offspring: experience in Zebu cattle (Bos indicus). Reproduction, Fertility and Development, v. 22, n. 1, p. 88-97, 2009.

MELLO, M. R. B. Clonagem em bovinos: uso de fibroblastos fetal e adulto como fonte doadora de núcleo. 2003. Tese de Doutorado. Universidade de São Paulo, 2003.

MIGLINO, M. A. Clonagem animal e placentação. Ciência e Cultura, v. 56, n. 3, p. 31-33, 2004.

MOGOLLÓN-WALTERO, E. M.; BOURG-DE MELLO, M. R.; BURLA-DÍAS, A. J. Clonagem de embriões bovinos a partir de células somáticas. Orinoquia, v. 18, n. 1, p. 95 104, 2014.

OBACK, B.; WELLS, D. N. Cloning cattle. Cloning \& Stem Cells, v. 5, n. 4, p. 243-256, 2003.

OGONUKI, N. et al. Early death of mice cloned from somatic cells. Nature Genetics, v. 30, n. 3, p. 253-254, 2002.

PANARACE, M. et al. How healthy are clones and their progeny: 5 years of field experience. Theriogenology, v. 67, n. 1, p. 142-151, 2007.

PEREIRA, A. F.; FREITAS, V. J. F. Clonagem em ruminantes: progressos e perspectivas atuais. Revista Brasileira de Reprodução Animal, Belo Horizonte, v. 33, n. 3, p. 118-128, 2009. 
POLEJAEVA, I. A. et al. Cloned pigs produced by nuclear transfer from adult somatic cells. Nature, v. 407, n. 6800, p. 86-90, 2000.

PRATHER, R. S. et al. Nuclear Transplantation in the Bovine Embryo: Assessment of Donor Nuclei and Recipient Oocyt. Biology of reproduction, v. 37, n. 4, p. 859-866, 1987.

PRATHER, R. S.; FIRST, N. L. Cloning embryos by nuclear transfer. Journal of reproduction and fertility. Supplement, v. 41, p. 125-134, 1990.

RIDEOUT, W. M.; EGGAN, K.; JAENISCH, R. Nuclear cloning and epigenetic reprogramming of the genome. Science, v. 293, n. 5532, p. 1093-1098, 2001.

ROBL, J. M. Development and application of technology for large scale cloning of cattle. Theriogenology, v. 51, n. 2, p. 499-508, 1999.

SILVA, T. J. C. Clonagem: o que aprendemos com Dolly?. Ciência e Cultura, v. 56, n. 3, p. 27-30, 2004.

TIAN, X. C. et al. Cloning animals by somatic cell nuclear transfer-biological factors. Reproductive Biology and Endocrinology, v. 1, n. 1, p. 98, 2003.

THIBIER, M. The zootechnical applications of biotechnology in animal reproduction: current methods and perspectives. Reproduction Nutrition Development, v. 45, n. 3, p. 235-242, 2005.

TRECENTI, A. S.; ZAPPA, V. Clonagem animal: Revisão de literaratura. Revista Científica Eletrônica de Medicina Veterinária, v.20, p.1-31, 2013.

VAJTA, G. et al. Handmade somatic cell cloning in cattle: analysis of factors contributing to high efficiency in vitro. Biology of Reproduction, v. 68, n. 2, p. 571-578, 2003.

VARAGO, F. B.; MENDONÇAS, L. F.; LAGARES, M de A. Produção in vitro de embriões bovinos: estado da arte e perspectiva de uma técnica em constante evolução. Revista Brasileira de Reprodução Animal, Belo Horizonte, v.32, n.2, p. 100-109, 2008.

VIEIRA, R. J. Biotécnicas aplicadas à reprodução bovina: generalidades. Revista Ciência Animal, Fortaleza, v. 22, n. 1, p. 55-65, 2012.

VISINTIN, J. A.; MELLO, M. R. B.; PECORA, M. Biotecnologias da reprodução animal: Clonagem e transgenia animal. Ciência Veterinária nos Trópicos, v. 11, n. 1, p. 139-144, 2008.

WELLS, D. N. Animal cloning: problems and prospects. Revue Scientifique Et Technique-Office International Des Epizooties, v. 24, n. 1, p. 251, 2005.

WILSON, J.M. et al. Comparison of birth weight and growth characteristics of bovine calves produced by nuclear transfer (cloning), embryo transfer and natural mating. Animal Reproduction Science, v. 38, n. 1- 2, p. 73-83, 1995. 
ZOU XIANGANG. et al. Production of cloned goats from enucleated oocytes injected with cumulus cell nuclei or fused with cumulus cells. Cloning, v. 3, n. 1, p. 31-37, 2001. 


\section{ASPECTO REPRODUTIVO DO JACARÉ-DE-PAPO-AMARELO (Caiman latirostris)}

\section{Bruna Kassia Nunes Eleutério}

Centro Universitário Fametro (UNIFAMETRO) - Campus Carneiro da Cunha, Fortaleza, CE Lattes: http://lattes.cnpq.br/6780600249581226

\section{Thalita Gomes Honorato}

Centro Universitário Fametro (UNIFAMETRO) - Campus Carneiro da Cunha, Fortaleza, CE Lattes: http://lattes.cnpq.br/5271822880082188

\section{Giovanna Cândido Carvalho Lima}

Centro Universitário Fametro (UNIFAMETRO) - Campus Carneiro da Cunha, Fortaleza, CE Lattes: http:/lattes.cnpq.br/1462897783689293

\section{Magida Thayane Araújo Aguiar}

Centro Universitário Fametro (UNIFAMETRO) - Campus Carneiro da Cunha, Fortaleza, CE Lattes: http://lattes.cnpq.br/5591333583797725

\section{Máyra Carvalho Petelinkar}

Universidade de Fortaleza (UNIFOR) - Centro de Ciências da Saúde, Fortaleza, CE

Lattes: http://lattes.cnpq.br/5981111350891482

\section{Fernando Paulino Alvarenga}

Universidade de Federal do Espírito Santo (UFES) - Campus Alegre, Alegre, ES

Lattes: http://lattes.cnpq.br/0289323245261247

\section{Melanie Ferreira Leite Jacintho Rabello}

Universidade de Federal de Uberlândia (UFU) - Campus Umuruama, Uberlândia, MG Lattes: http://lattes.cnpq.br/8079171297521892

\section{Victor Hugo Vieira Rodrigues}

Centro Universitário Maurício de Nassau (UNINASSAU), Centro de Saúde, Fortaleza, CE Lattes: http://lattes.cnpq.br/2226604565550002

Informações sobre o artigo:

Recebido em:

28/06/2021

Aceito em:

30/06/2021

Data de publicação:

19/07/2021

Palavras-chave:

Crocodilianos

Biologia reprodutiva

Nidificação

\section{RESUMO}

O jacaré-de-papo-amarelo (Caiman latirostris) faz parte da ordem dos crocodilianos. A reprodução desses animais é dividida por etapas, com a preparação do reprodutor, o local e material para formar os ninhos, incubar e eclodir os ovos, sendo este último um fator importante para auxiliar na conservação da espécie. Desta forma, objetivou-se neste trabalho realizar uma revisão bibliográfica com levantamento de trabalhos que dizem a respeito de reprodução de jacaré-de-papo-amarelo, pontuando sobre sua biologia, comportamento de nidificação, importância para conservação e ameaças naturais. Como resultado do estudo verificou-se que eles têm uma reprodução complexa e um comportamento de nidificação característico. É essencial o conhecimento da espécie e o entendimento da população para que haja conservação da mesma. 


\section{REPRODUCTIVE ASPECTS OF THE YELLOW CROP ALLIGATOR (Caiman latirostris)}

The broad-snouted caiman (Caiman latirostris) is part of the order of crocodilians. The reproduction of these animals is divided into stages, with the preparation of the breeder, the place and material to form nests, egg incubation, and hatchling management, this being an important factor to assist in the conservation of the species. This paper aims to perform a literature review based on updated material on reproduction of the broad-snouted caiman, specifying about its biology, nesting behavior, importance for

Keywords:

\section{Crocodilians}

Reproductive biology

Nesting conservation and natural threats. As a result of the study it was found that they have a complex breeding and characteristic nesting behavior. Knowledge of the species and understanding of the population are essential for its conservation.

\section{INTRODUÇÃO}

Os répteis fazem parte de uma classe com cerca de 7000 espécies, evoluindo constantemente e proporcionando uma enorme variação fisiológica e morfológica (ZACARIOTTI et al., 2007; SCHÚ et al., 2015). O Caiman latirostris é um crocodiliano de porte médio e que, na natureza, já foi relatado machos de três metros e meio. Já as fêmeas, são normalmente encontradas com cerca de até dois metros, onde abrangem várias bacias costeiras e agindo dentro dos ecossistemas onde estão inseridos (FERNÁNDEZ et al., 2015; MASCARENHAS, 2019).

A reprodução dos jacarés possuem etapas importantes, compreendidas como a preparação do reprodutor, do local e do material para a formação dos ninhos, incubação e eclosão dos ovos (SARKIS-GONÇALVES, 2001). Através de estudos realizados com animais em cativeiro mostrou-se que a idade aproximada do período de reprodução se inicia por volta dos cinco anos de idade (VERDADE, 2003; VILLELA, 2004). A construção dos ninhos normalmente se dá pela formação de montes compostos de substratos diversos de matéria orgânica, podendo variar por espécie e indivíduo, postos nas épocas mais secas do ano (MASCARENHAS, 2019).

A conservação da espécie pode ser caracterizada como complexa, sendo evidenciada principalmente na criação em cativeiro. O jacaré-de-papo-amarelo não se 
encontra na lista publicada pelo IBAMA de animais ameaçados de extinção, mas ainda é uma espécie bastante acometida pelo declínio populacional em locais determinados (VILLELA, 2004; NÓBREGA, 2017). A densidade populacional varia de acordo com a distribuição, podendo estar quase extinto em locais com muita ação antrópica e possuir grandes quantidades de indivíduos em áreas conservadas (VILLELA, 2004).

\section{QUEM SÃO OS JACARÉS-DE-PAPO-AMARELO?}

O Caiman latirostris (derivado do latim "latis", largo e amplo, e "rostris", focinho), conhecido popularmente por jacaré-de-papo-amarelo no Brasil, pertence à Família Crocodylidae e Subfamília Alligatoridae. É considerado um crocodiliano de porte médio, com registros de indivíduos machos medindo de dois a três metros e meio, que ocupa rios, mangues, pântanos, lagoas e áreas selvagens, estando presente em grande parte dos continentes da América Latina (MASCARANHAS JÚNIOR, 2019). Segundo Coutinho et al. (2013), estima-se que 70\% da sua distribuição global encontra-se em território brasileiro.

A alimentação da espécie jovem (Figura 1) é baseada em invertebrados e pequenos invertebrados (moluscos, artrópodes e crustáceos) e pequenos vertebrados (peixes e anfíbios). $\mathrm{Na}$ fase adulta, a dieta indica a presença de peixes maiores, outros répteis, aves e pequenos mamíferos. Sendo os moluscos itens importantes para a composição da dieta desses animais em todos os estágios de desenvolvimento (NÓBREGA, 2017).

Figura 1 - Filhotes de jacaré-de-papo-amarelo (Caiman latirostris).

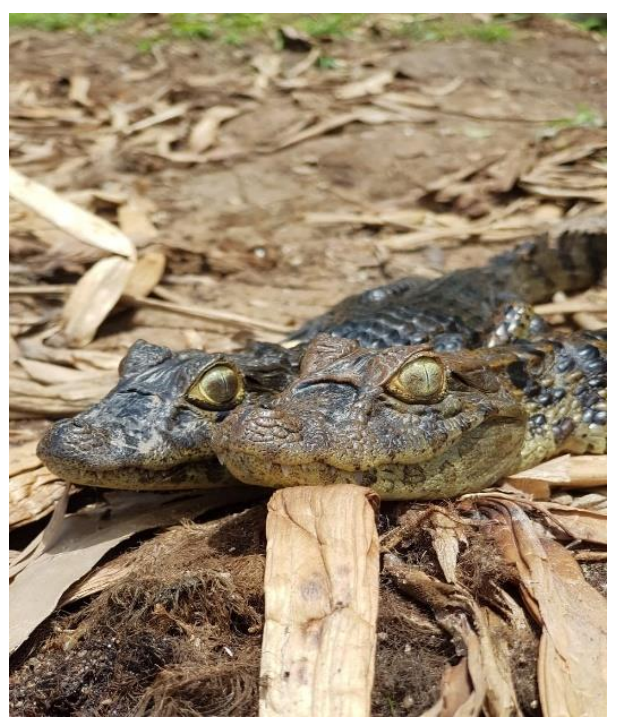

Fonte: Paulo Braga/Liar (UFRPE) 
O jacaré-de-papo-amarelo possui um importante papel na cadeia alimentar do ambiente onde vive, sendo responsável pela regulação da população de peixes, moluscos, insetos, anfíbios, répteis, mamíferos e aves aquáticas. Além disso, suas fezes servem de matéria orgânica para enriquecer as águas, fornecendo também, recursos energéticos para diversos organismos encontrados em seu habitat (ALMONACID et al., 2007; COUTINHO et al., 2013).

\section{BIOLOGIA REPRODUTIVA}

O jacaré-de-papo-amarelo apresenta um complexo comportamento reprodutivo, contando com várias fases. Para o cortejo, os grandes machos (mais dominantes) apresentam uma série de ações com o intuito de chamar a atenção das fêmeas. Várias manobras foram relatadas, como emitir sons, produzir vibrações dentro da água e elevar o próprio corpo (CUBAS, 2017; MERCON, 2019). Apenas os machos "alfa" são escolhidos pelas fêmeas, também dominantes, para a fertilização e é comum a paternidade compartilhada da prole (GRIGG, 2015).

É importante lembrar que o ciclo reprodutivo dos crocodilianos conta com a influência da sazonalidade e não apresenta ovulação em ciclos contínuos. Sendo grandes animais ectotérmicos, a evolução e retração das gônadas por ação dos hormônios está diretamente ligada com o período anual e temperatura ambiente. As fêmeas em período préreprodutivo costumam disputar por locais com "banhos de sol", favorecendo um bom desenvolvimento gonadal das fêmeas dominantes (Figura 2), sendo a influência social, também um fator importante para a reprodução (GRIGG, 2015; CUBAS, 2017; TROIANO,2018). 
Figura 2 - Ninho de jacaré-de-papo-amarelo (Caiman latirostris) em estrutura de "monte" com diversos substratos para a manutenção da temperatura

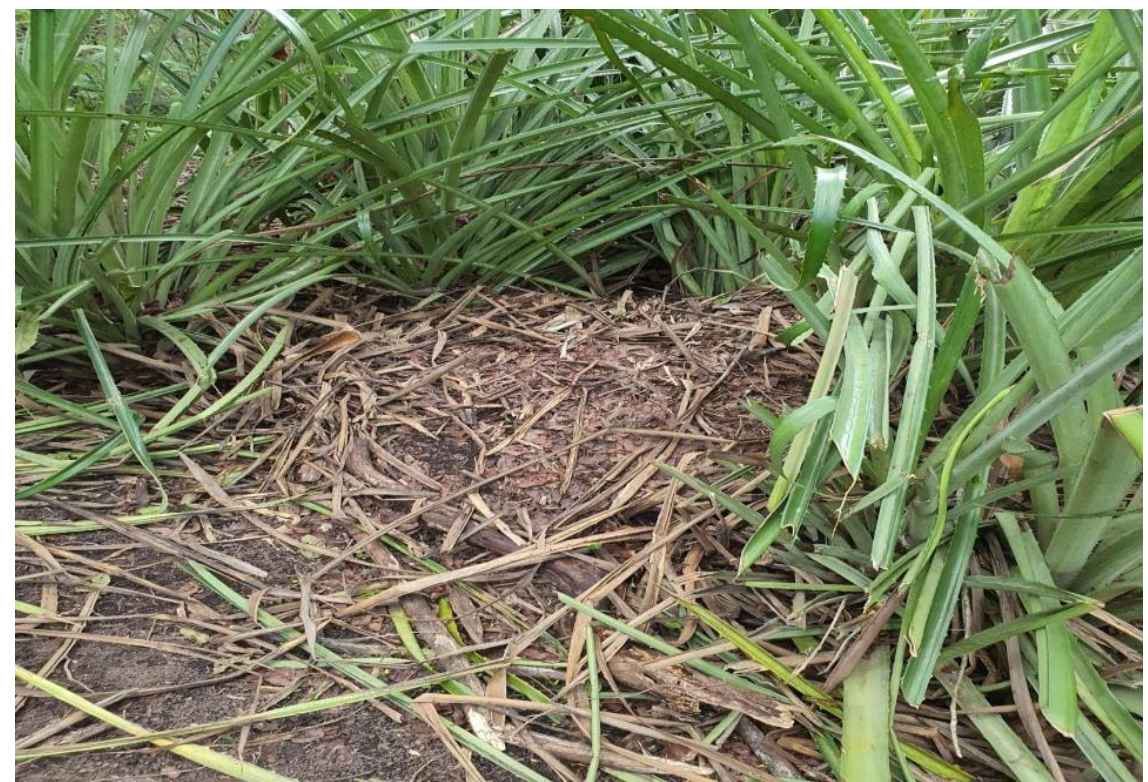

Fonte: Paulo Braga/Liar (UFRPE)

Quando jovens, os crocodilianos não diferem muito na sua anatomia reprodutiva, sendo difícil a avaliação das gônadas. Em indivíduos machos adultos em idade para a reprodução, observa-se um par de testículos arredondados próximos aos rins. Os ductos deferentes são observados ao longo da borda caudolateral do testículo, unindo-se na região da base do falo, anatomicamente situada no assoalho da cloaca vertical. O falo só é exposto no momento do acasalamento, antes disso, fica retido na cloaca. As fêmeas em idade reprodutiva, apresentam um par de ovários em localização semelhante aos testículos, ventralmente na face craniomedial dos rins (CUBAS, 2017; TROIANO, 2018).

Para a identificação de indivíduos de sexos distintos em cativeiro, pode-se fazer o uso de espéculo vaginal veterinário e protusão do órgão copulatório por compressão lateral da região cloacal, expondo o "falo" do indivíduo do sexo masculino, ou observando o órgão interno feminino (SILVA, 2018; TROIANO, 2018).

\section{COMPORTAMENTO DE NIDIFICAÇÃO}

O jacaré-de-papo-amarelo pode utilizar habitats distintos para nidificação, mostrando assim, a sua adaptação ao meio. Foi observado o uso de tapetes de vegetação flutuante no rio Paraná, além de ambientes de floresta e de savana, restinga, mata ciliar, manguezal, floresta e até em ambientes urbanizados (COUTINHO et al., 2013). 
Os ninhos apresentam uma estrutura em forma de "monte" (Figura 2), feita de matéria orgânica (folhas, galhos), monte de terra, e em caso de animais próximos a ambientes urbanos, lixo, e sempre próximo a água. Foram observados ninhos com o tamanho médio de $49 \mathrm{~cm}$ de altura x $134 \mathrm{~cm}$ de comprimento x $103 \mathrm{~cm}$ de largura. Geralmente, as fêmeas optam por fazer seus ninhos com uma distância média de até dois metros do solo para a água, promovendo assim, um excelente cuidado parental contra predadores, diferente dos outros répteis. Porém, já foram relatados ninhos que se encontravam a com até dois Km da água, demonstrando como esse animal pode se adaptar a diferentes ambientes (CUBAS, 2017; MERCON et al., 2019).

Todos os crocodilianos são ovíparos e apresentam fertilização interna. A temperatura é um fator importante para determinar o gênero dos filhotes, que não sofrem influência cromossômica, diferente de outras espécies (GRIGG, 2015; TROIANO et al., 2018). O período para a ovipostura pode ser relativo. Relata-se que nos meses entre outubro e fevereiro, o número de ovos depositados variam de 10 até 50 unidades. Porém, segundo Mercon et al. (2019), pode-se encontrar ninhos com diferentes ninhadas reunidas, ovipostos por fêmeas distintas, alcançando números de até 130 ovos. Tudo isso com influência direta da idade reprodutiva, tamanho da fêmea, oferta de alimento e condições ambientais como o clima e ciclo de chuvas.

Para a maioria dos crocodilianos, a determinação sexual é termodependente, onde em temperaturas abaixo de $28^{\circ} \mathrm{C}$ dão origem para indivíduos machos e em temperaturas acima de $30^{\circ} \mathrm{C}$, fêmeas (TROIANO, 2018). Para o Caiman latirostris a determinação sexual se dá com fêmeas nas temperaturas entre $29^{\circ} \mathrm{C}$ e $31^{\circ} \mathrm{C}$, e machos para acima de $33^{\circ} \mathrm{C}$. Os filhotes apresentam uma coloração característica amarelo-esverdeada com manchas pretas que acompanham da região rostral até a cauda. São pequenos, alcançando tamanhos entre 25 a $30 \mathrm{~cm}$. Ainda dentro do ovo, emitem sons, sinalizando para a mãe que a ruptura da casca está próxima.

Para quebrar a casca do ovo, contam com um acessório importante, o "dente de ovo". Trata-se de uma estrutura na ponta do focinho que auxiliará na quebra e saída dos ovos. Após o nascimento, a mãe apresenta um importante cuidado parental (Figura 3), diferente de outros répteis. Esse cuidado pode durar por meses (CUBAS, 2017; MERCON, 2019). 
Figura 3 - Indivíduo fêmea de jacaré-de-papo-amarelo (Caiman latirostris) protegendo o seu ninho em ambiente natural, na Estação Ecológica de Tapacurá, Pernambuco

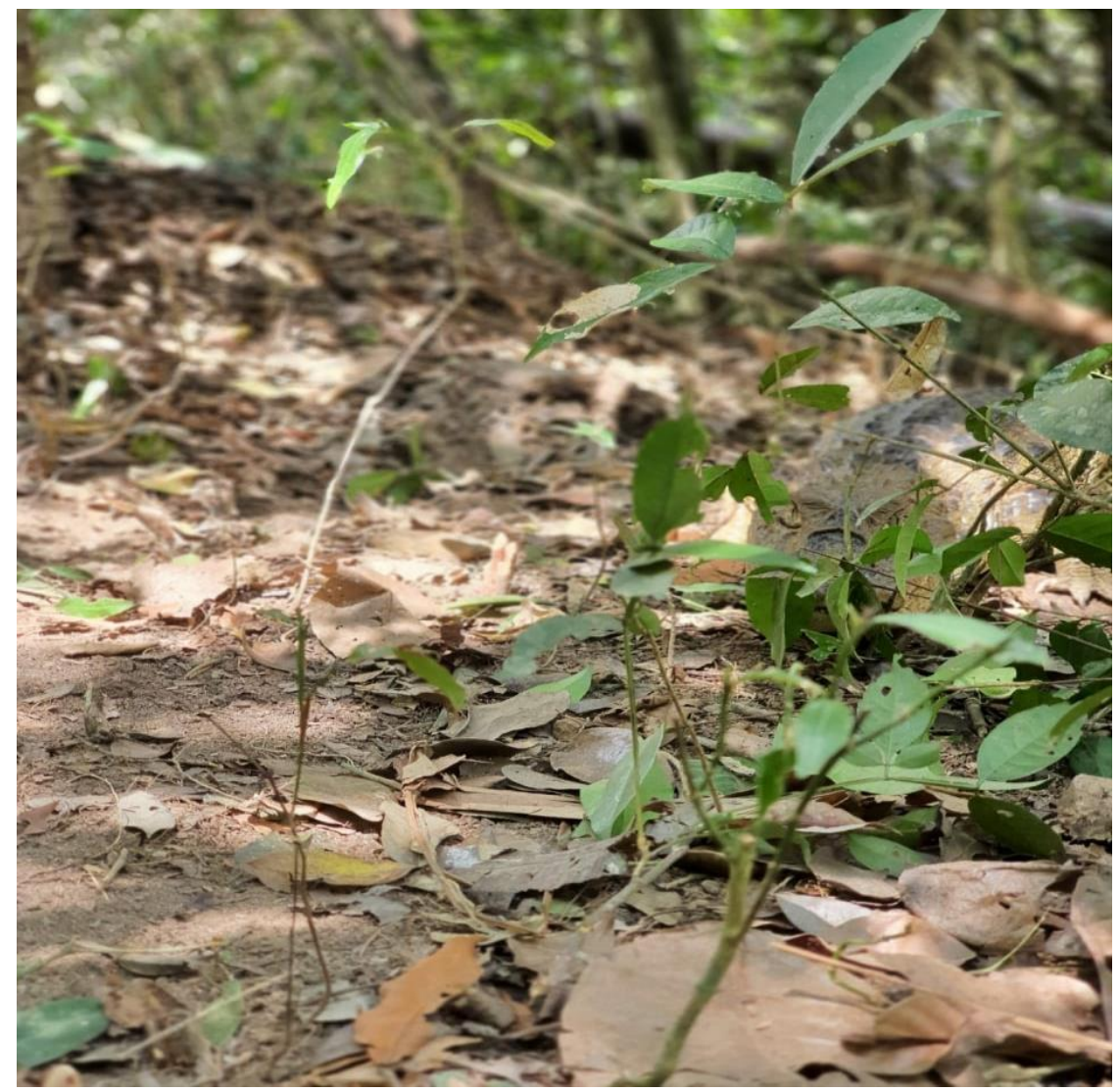

Fonte: Paulo Braga/Liar (UFRPE)

\section{IMPORTÂNCIA DA REPRODUÇÃO PARA A CONSERVAÇÃO DA ESPÉCIE}

Conhecer a ecologia das espécies é essencial para a conservação (ANDRU e QUIROZ, 2003; LUZ, 2012), e para que a mesma seja eficaz Coutinho et al. (2013) destacam algumas estratégias, como enfatizar a importância das unidades de conservação e aplicar as leis ambientais em prol do jacaré-de-papo-amarelo.

Segundo Verdade (1997), a criação em cativeiro pode promover meios bastante eficientes para a conservação do jacaré-de-papo-amarelo na natureza e também para estudos sobre saúde, bem-estar, reprodução, biologia e manejo desses animais. Esse sistema tem sido a melhor prática para a conservação e manejo do jacaré-de-papo-amarelo no Brasil, onde o método mais utilizado e que vem obtendo maior sucesso é a prática de reprodução farming que consiste no ciclo completo da vida do animal, incluindo a parte de manejo reprodutivo (ASHLEY, 1996)

Projetos de criação e manejo de espécies nativas podem ser benéficas também para evitar possíveis desequilíbrios ecológicos e danos que uma criação de espécies exóticas 
podem causar. (VERDADE, 2003) Um quesito de extrema importância, afinal, quanto maior for o tempo para os indivíduos de determinada espécie entrarem em período reprodutivo, maior o tempo de geração e menor a taxa de incremento populacional (CAUGHLEY, 1977).

Podemos citar também o caso da arara-azul, que por ter características atraentes é um dos grupos de aves mais ameaçados do mundo (GUEDES, 2004). Com isso, objetivouse marcar e monitorar os ninhos, ovos e filhotes, como também coletar os dados biológicos, fazer o mapeamento de ninhos e locais de alimentação, manejar ninhos, ovos e filhotes e também promover a educação ambiental e incentivar o turismo ecológico e a analisar o impacto deste (GUEDES, 2004).

\section{AMEAÇAS NATURAIS}

A pressão antrópica é um fator relevante nas alterações dos ecossistemas, contribuindo para a degradação do ambiente (CUBAS et. al, 2017), esse fato é consequência da superioridade que foi imposta pelo homem sobre a natureza, resultando em domínio excessivo (MARIANO et al., 2011). Segundo Peres et al. (2020), o mundo está enfrentando uma das piores crises com a perda da biodiversidade como descrito na Lista Vermelha de Espécies Ameaçadas de Extinção de 2008 (Vié et al., 2009). Quando o assunto é conservação o Caiman latirostris possui uma situação complexa (VILLELA, 2004). Mesmo que no Brasil a espécie tenha deixado de ser considerada ameaçada de extinção, atividades como desmatamento, poluição, drenagem de lagos e rios, expansão urbana e o uso intensivo de agrotóxicos vem causando a redução de habitat natural desses indivíduos, assim também causando uma baixa populacional devido às ameaças constantes pela ocorrência da espécie em áreas urbanas, assim estando ainda mais sujeito a caça que.

Segundo Filogônio et al. (2010), muitas mortes têm sido causadas por pescadores que visam evitar que suas redes de pesca sejam danificadas por esses animais durante a tentativa de se alimentar dos pescados. Como os crocodilianos têm distribuição exclusiva no ambiente aquático (Figura 4), isso acaba sendo um fator de maior pressão humana sobre o seu habitat (SIMONCINI, 2011; LUZ, 2012). 
Figura 4 - Indivíduo de jacaré-de-papo-amarelo (Caiman latirostris), na Estação Ecológica de Tapacurá, Pernambuco.

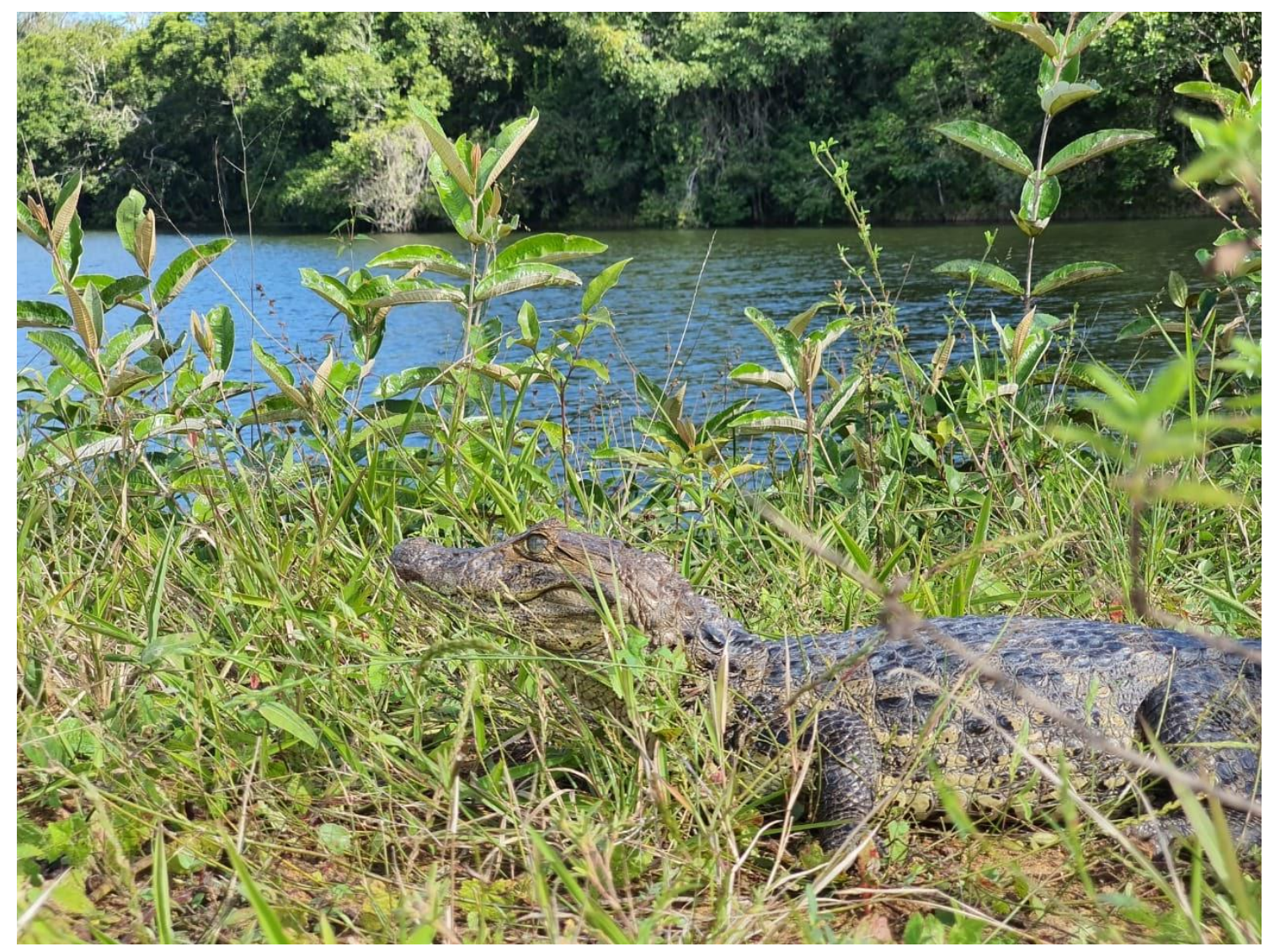

Fonte: Paulo Braga/Liar (UFRPE)

Os jacarés vêm sendo encontrados com mais frequência em esgotos, valões e áreas alagáveis, sendo cada vez mais avistados em meio às cidades onde estão sujeitos a acidentes, ataques e doenças. A caça e a exploração comercial de jacarés buscando a produção e a extração de carne e couro tem um grande impacto na redução populacional desses animais. Principalmente os mais jovens, uma vez que o aproveitamento de pele é maior nos indivíduos mais novos por não terem formado ainda os osteodermos ventrais (LEAK et al., 1987).

A poluição de lagos e rios também é um dos agravantes principais para a diminuição de população desses animais, pois além de causar a contaminação de inúmeros organismo aquáticos, também causa um enorme desequilíbrio ecológico e fisiológico, podendo ocasionar diversas doenças infecciosas ou infecções parasitárias (Merchant et al., 2018). Além disso, os crocodilianos podem acabar morrendo por inundação ou predação durante seu desenvolvimento embrionário (SIMONCINI et al., 2016). Em relação ao Caiman latirostris a estimativa é de que apenas 30 a 40\% dos ovos eclodem, devido a esses 
eventos (SIMONCINI et al., 2016). Além desses fatores, COUTINHO et al., 2013 citam que a predação dos ninhos por raposas, lagartos, quatis, aves, além do ataque por cupins, formigas, fungos e bactérias são as maiores causas de mortalidade embrionária (COUTINHO et al., 2013).

A umidade e a temperatura do ambiente podem contribuir para o surgimento de bactérias e fungos. Em um estudo realizado por Nóbrega et al. (2019), foi encontrado a presença de agentes infecciosos em ovos e ninhos de Caiman latirostris. Nos ovos foram

encontrados K. pneumoniae, Bacillus cereus, Leclercia adecarboxylata, Klebsiella ozaenae, Acinetobacter baumannii-calcoaceticus e Pseudomonas aeruginosa. Já nos ninhos foi encontrado a presença de Enterobacter cloacae, K. pneumoniae, K. ozaenae e B. cereus.

\section{CONSIDERAÇÕES FINAIS}

O jacarédepapoamarelo possui uma reprodução complexa, agindo em diversas etapas, desde ações até produção de sons, juntamente com diferenças anatômicas. Existem afinidades comportamentais entre os répteis, principalmente com crocodilianos, mas se tratando do comportamento de nidificação estes demonstram características particulares da espécie.

A etiologia se mostra essencial para efetivar a conservação. Com a criação em cativeiro é permitido o estudo da reprodução, biologia, saúde, manejo, dentre outros, garantindo melhores condições de conservação. O contato excessivo da ação antrópica com o meio ambiente vem sendo a maior ameaça à espécie. Com a degradação do ambiente caça e exploração do comércio, poluição dos rios e lagos, os crocodilianos acabam estando frequentemente em risco de desequilíbrio populacional.

O conhecimento sobre a biologia, importância ecológica e cultural, reprodução e comportamento do jacaré-de-papo-amarelo em seu ambiente natural, torna-se essencial para analisar suas características e gerir de forma segura a conservação destas populações. O contato excessivo da ação antrópica com o meio ambiente vem sendo a maior ameaça à espécie, apesar disso, o Caiman latirostris vem se mostrando um exemplo de sobrevivência e adaptação, estando fortemente presente em meios urbanos e poluídos e se adaptando a estes. Com a degradação dos hábitats, estes animais encontram-se em constante desequilíbrio populacional, lutando de maneira contundente, para a sua sobrevivência. Além de estudos sobre a espécie, é necessário o entendimento da população, que tem como um "vilão" o 
jacaré nativo. $\mathrm{O}$ ensino por via da educação ambiental aliado a reprodução em cativeiro pode facilitar a promoção de pesquisas mais eficientes sobre a conservação do jacaré-de-papoamarelo, sua reprodução, biologia e função ecológica. Desta forma, é fundamental que realizem mais estudos a respeito do assunto para compreender a dinâmica populacional da espécie, assegurando sua conservação.

\section{AGRADECIMENTOS}

Agradecemos ao Biólogo, mestre em saúde Humana e Meio Ambiente, integrante do laboratório interdisciplinar de anfíbios e répteis da UFRPE, Paulo Braga pela excelente contribuição de imagens para a presente revisão.

\section{REFERÊNCIAS}

CAMPOS, Z. \& MOURÃO, G. Caiman latirostris (broad-snouted caiman) nesting. Herpetological Review, v. 26, p. 203-204, 1995.

COUTINHO M. E. et al. Avaliação do risco de extinção do jacaré-de-papo-amarelo Caiman latirostris (Daudin, 1802) no Brasil. Biodiversidade Brasileira. v. 3, n. 1, p. 13 - 20, 2013.

CUBAS, Z. S. et al. Conservação e Bem-estar Animal. $2^{\circ}$ ed. São Paulo. Roca, p. 25, 2017.

FERNÁNDEZ, L. M. et al. Analysis of population density and distribution of Spectacled Caiman (Caiman crocodilus) in Caño Palma, Northeast Costa Rica. Herpetological Conservation and Biology, v. 10, n. 3, p. 959-968, 2015.

GRIGG, G. C. Biology and evolution of crocodylians. p. 431- 435, 2015.

KUSHLAN, J. A. \& Kushlan, M.S. Function of nest attendance in the American alligator, Herpetologica, p. 27-32, 1980.

LARRIERA, A. Caiman latirostris (broad-snouted caiman). Communal nesting. Herpetological Review, v. 33, n. 3, p. 202, 2002.

LUZ, C. da. Conservação de Caiman latirostris (Daudin, 1801): interações entre pescadores e o jacaré-de-papo-amarelo na comunidade Barra do João Pedro, no município de Maquiné, no RS. Porto-Alegre, 2012.

MADER, D. R. \& DIVERS, S. J. Current Therapy in Reptile Medicine and Surgery-E-Book. Elsevier Health Sciences, p. 79, 2013.

MARIANO, Z. F. et al. A Relação Homem-natureza e os Discursos Ambientais. Revista Do Departamento De Geografia, v. 22, p. 158-170, 2011. 
MASCARENHAS JÚNIOR, P. B. Inferências morfofisiológicas de Caiman latirostris (archosauria: crocodylia) baseadas na histologia óssea. Dissertação de Mestrado. Universidade Federal de Pernambuco, 2019.

MERCHANT, M. et al. Nest attendance patterns in the American alligator (Alligator mississippiensis), Copeia 106, v. 3, p. 421-426, 2018.

MERCON, L. et al. "Marginais" Jacarés da Mata Atlântica. ed. Vitória: Instituto Marcos Daniel, v. 1, p. 75-77, 2019.

NÓBREGA, Y. C. Avaliação da saúde de jacarés-de-papo-amarelo (Caiman latirostris) em condições in situ e ex situ no Espírito Santo, Sudeste do Brasil. Dissertação (mestrado em Ciência Animal) - Universidade Vila Velha, 2017.

PERES, M. B. et al. Avaliação do Estado de Conservação da Fauna Brasileira e a Lista de Espécies Ameaçadas: o que significa, qual sua importância, como fazer?. Bio Brasil - Revista Científica, 2020.

ROSS, J. P. Crocodiles: status survey and conservation action plan. IUCN, Gland (Suiza). SSC Crocodile Specialist Group, 1998.

RUEDA-ALMONACID, J.V. et al. Las Tortugas y los cocodrilianos de los países andinos del Trópico. Serie Guías Tropicales de Campo, Conservación Internacional, Bogotá, 2007.

SIMONCINI, M. S. et al. Avaliação de fatores associados à predação em ninhos de Caiman latirostris (Crocodylia: Alligatoridae) na Argentina. Phyllomedusa: Journal of Herpetology, v. 15, n. 2, p. 137-146, 2016.

SARKIS-GONÇALVES, F. et al. Manejo de jacarés-de-papo-amarelo (Caiman latirostris) em cativeiro. A produção animal na visão dos brasileiros. Piracicaba: Sociedade Brasileira de Zootecnia, p. 565-579, 2001.

SCHÚ, C. et al. Manejo reprodutivo de crocodilianos. Investigação, v. 14, n. 1, 2015.

SILVA, F. P. Aspectos Morfológicos Associados ao Dimorfismo Sexual. Dissertação de Pósgraduação, 2018.

TROIANO, J.C. Doenças dos Répteis. Editora MedVet, São Paulo, SP, p. v. 1, p. 26-29. 2018.

VERDADE, L. M. Cranial sexual dimorphism in captive adult broad-snouted caiman (Caiman latirostris). Amphibia reptilia, v. 24, n. 1, p. 92-99, 2003.

VERDADE, Luciano M. \& SARKIS, F. Age at first reproduction in captive Caiman latirostris (broad-snouted caiman). Herpetological Review, v. 29, n. 4, p. 227, 1998.

NÓBREGA, Y. C. et al. Biological hazard associated with bacteria from nests and eggs of Caiman latirostris (Daudin, 1802). Herpetology notes. v. 12, p. 905-908, 2019. 
SARKIS-GONÇALVES, F. et al. Manejo de Jacarés-de-Papo-Amarelo (Caiman latirostris) em Cativeiro. Herpetology Review. v. 23, p. 3, 2001.

VILLELA, P. M. S. Caracterização genética de populações de jacarés-de-papo-amarelo (Caiman latirostris), utilizando marcadores microssatélites. Dissertação (Mestrado em Ecologia de Agroecossistemas) - Escola Superior de Agricultura "Luiz de Queiroz", Universidade de São Paulo, Piracicaba, p. 114, 2004.

BULL, J. J. Sex deterrnination in reptiles. The Quarterly Review of Biology. v.55, n. 1, p. 321, 1980.

WIBBELS, T. et al. Temperature-dependent sex determination in the red-fared slider turtle, trachemys scripta. Journal of Experimental Zoology, v. 281. n.5, p. 409-416, 1988.

VILLELA, P. M. S.; Caracterização genética de populações de Jacaré-de-papo-amarelo (Caiman latirostris) utilizando marcadores microssatélites (DAUDIN, 1802). Herpetology notes, 2004.

CAUGHLEY, G. Sampling in aerial survey. Journal Wildlife.Manage. v.41, p. 605-615, 1977.

CAUGHLEY, G. \& SINCLAIR, A. R. E. Wildlife Ecollogy and Management. Boston: Blackwell Science, p. 334, 1994.

ZACARIOT'TI, R. L. et al. Semen collection and evaluation in free-ranging Brazilian rattlesnakes (Crotalus durissus terrificus). Hoboken: Wiley Subscription Services, Inc., A Wiley Company, 2007. 


\title{
AVALIAÇÃO MORFOLÓGICA DE ESPERMATOZOIDES EQUINOS CORADOS COM EOSINA-NIGROSINA E PANÓTICO RÁPIDO
}

Francisco de Assis Vieira Feitosa Moreira

Faculdade Terra Nordeste, FATENE, Caucaia, CE

\section{Michelle Costa e Silva}

Faculdade Terra Nordeste, FATENE, Caucaia, CE

Lattes: http://lattes.cnpq.br/2140592626597725

ORCID: https://orcid.org/0000-0003-3563-3812

\author{
Alan Diniz Lima \\ Faculdade Terra Nordeste, FATENE, Caucaia, CE \\ Lattes: http://lattes.cnpq.br/7381425013607892

\section{Paula Bittencourt Vago} \\ Faculdade Terra Nordeste, FATENE, Caucaia, CE \\ Lattes: http://lattes.cnpq.br/2140592626597725 \\ ORCID: https://orcid.org/0000-0003-3563-3812
}

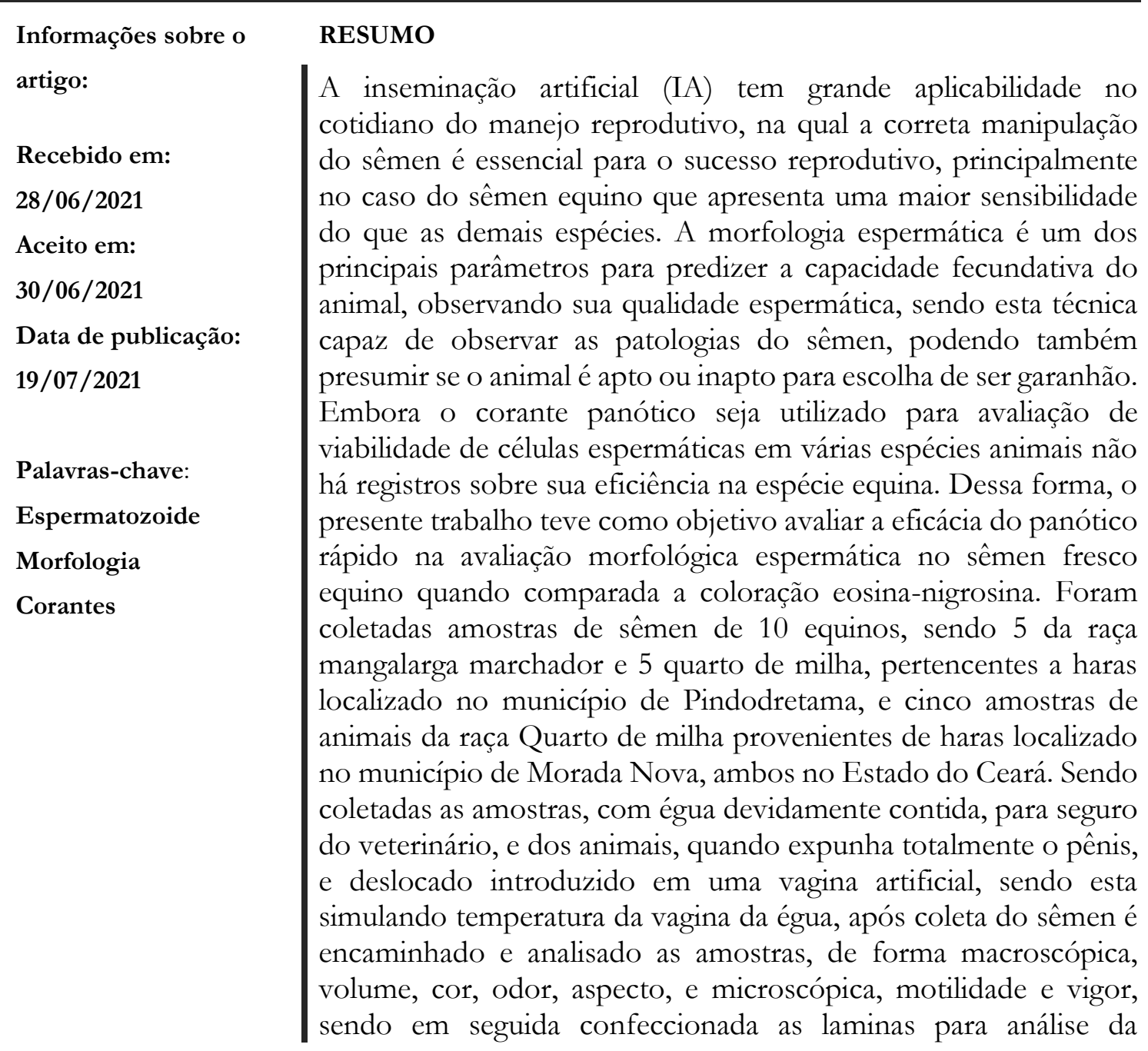


morfologia seminal. De posse dos dados foram tabulados em planilhas e analisados as medias por grupos, de forma descritiva. Dos 10 equinos utilizados, foram obtidos 2 mil espermatozoides para análise de vigor e motilidade, além da avaliação morfológica. Para cada animal foram confeccionadas duas lâminas com os corantes eosina-nigrosina, considerado o padrão ouro, e o panótico rápido, nos quais foram avaliados $100 \mathrm{SPTZ}$ por lâmina de cada corante por meio de microscopia ótica com aumento de 100x. O panótico rápido pode ser utilizado na rotina de avaliação morfológica de espermatozoides equinos, sendo uma coloração rápida, de custo acessível e eficaz na identificação de patologias das células espermáticas, podendo ser utilizada em programas de reprodução equina.

\section{MORPHOLOGICAL EVALUATION OF EQUINE SPINE EQUINE STAINED WITH EOSIN NIGROSIN AND FAST PANOTIC}

Artificial insemination (AI) has great applicability in the daily reproductive management, in which the correct handling of semen is essential for reproductive success, especially in the case of equine semen, which is more sensitive than other species. Sperm morphology is one of the main parameters to predict the fertility capacity of the animal, observing its sperm quality, being this technique capable of observing the pathologies of the semen, and it can also presume whether the animal is fit or unfit to choose to be a stallion. Although the panotic dye is used to evaluate the viability of sperm cells in several animal species, there is no record of its efficiency in the equine species. Thus, the present study aimed to evaluate the efficacy of rapid panotic in the sperm morphological evaluation in fresh equine semen when compared to eosin-nigrosine staining. Semen samples were collected from 10 horses, 5 of which were mangalarga gaiters and 5 quarter of a mile, belonging to stud farms located in the municipality of Pindodretama, and five samples of animals of the quarter mile breed from stud farms located in the municipality of Morada Nova, both in the State of Ceará. Samples were collected, with properly contained mare, for the veterinarian's insurance, and the animals, when fully exposed the penis, and moved inserted into an artificial vagina, simulating the mare's vagina temperature, after collecting the semen, it is forwarded and analyzed the samples, in macroscopic form, volume, color, odor, appearance, and microscopic, motility and vigor, then the slides were made for analysis of seminal morphology. In possession of the data, they were tabulated in spreadsheets and the means were analyzed by groups, descriptively. Of the 10 horses used, 2,000 sperm were obtained for analysis of vigor and motility, in addition to morphological evaluation. For each animal, two slides were made with the eosin-nigrosine dyes, considered the gold standard, and the fast panotic, in which 100 SPTZ per slide of each dye were evaluated using optical microscopy with a $100 \mathrm{x}$ magnification. Rapid panotic can be used in the routine of morphological 
evaluation of equine sperm, being a fast, affordable and effective stain in the identification of sperm cell pathologies, and can be used in equine breeding programs.

\section{INTRODUÇÃO}

A inseminação artificial (IA) tem grande aplicabilidade no cotidiano do manejo reprodutivo, no entanto a coleta do sêmen tem que ser realizada de maneira higiênica e sem que ocorra danos ao animal e ao veterinário, havendo a correta manipulação do sêmen que é essencial para o sucesso reprodutivo, principalmente no caso do sêmen equino que apresenta uma maior sensibilidade do que as demais espécies (OLIVEIRA et al., 2013; WOODS et al., 1990).

Para ocorrer a fecundação é necessário que o espermatozoide esteja íntegro para realizar esta função, apresentando adequado metabolismo energético, motilidade progressiva, enzimas do acrossoma, proteínas plasmáticas, distribuição de lipídeos no plasma e na membrana do acrossoma, assim como as proteínas da membrana plasmática, responsáveis por auxiliar na sobrevivência dos espermatozoides no trato feminino (AMANN e GRAHAN, 2011).

Assim, para que a inseminação artificial possa apresentar os melhores resultados na espécie equina é necessário um estudo mais amplo sobre os testes utilizados para analisar a viabilidade dos espermatozoides submetidos à refrigeração, congelação e descongelação, uma vez que após esses processos danos à integridade da membrana espermática parecem exercer papel crítico na sobrevivência do espermatozoide no trato genital da fêmea (DE ARRUDA et al., 2011).

A utilização de um único método convencional para avaliação espermática é muito limitada para predizer o potencial de fecundação objetivando a qualidade do sêmen, isto se deve às diferentes funções e componentes seminais (MAZIERO et al., 2009).

A motilidade, concentração e morfologia espermáticas são os parâmetros clássicos na avaliação de amostras de sêmen (fresco, resfriado ou congelado). Usualmente, a motilidade espermática é estimada em análise do sêmen entre lâmina e lamínula, enquanto as anormalidades espermáticas são avaliadas em esfregaços corados. Ambas as técnicas são realizadas sob uso de microscopia óptica (ARRUDA et al., 2007). Assim, a fim de avaliar a qualidade seminal em equinos, são utilizadas análises físico-químicas, testes hiposmóticos, 
avaliação de vigor e motilidade (JASKO et al., 1990), bem como também análises morfológicas das células espermáticas através de corantes específicos (ARRUDA et al., 2007).

Entre os corantes já utilizados para avaliação da morfologia espermática podem ser citados a eosina-anilina azul (VANDER SCHAAF, 1952), Spermac (OETTL, 1986), Giemsa (GRAHAM, 1996), sondas fluorescentes como o brometo de etídeo, iodeto de propidio (PI) e a aglutinina de Psiun sativun (PSA), quando associados a isotiocinato de fluroceina (FITC) (ARRUDA et al., 2007). Na rotina de avaliação espermática a coloração mais usada é a eosinanigrosina com a finalidade de avaliar os espermatozoides vivos e mortos, onde os núcleos dos espermatozoides vivos não se coram em vermelho (DOTT e FOSTER, 1972).

O corante panótico rápido tem se mostrado uma técnica rápida e bastante eficaz para a coloração e esfregaço de amostras de sêmen, permitindo a fácil identificação morfológica das células espermáticas (CHACUR et al., 2004).

Embora o corante panótico seja utilizado para avaliação de viabilidade de células espermáticas em várias espécies animais, não há registros sobre sua eficiência na espécie equina. Dessa forma, o presente trabalho teve como objetivo avaliar a eficácia do panótico rápido na avaliação morfológica espermática no sêmen fresco equino quando comparada à coloração de eosina-nigrosina.

\section{MATERIAL E MÉTODOS}

O presente experimento foi aprovado pela Comissão de Ética no Uso de Animais da Faculdade Terra Nordeste (FATENE) sob número de registro 002/2020. Para a realização do mesmo foram coletadas amostras de sêmen de 10 equinos, sendo cinco animais da raça Mangalarga Marchador, pertencentes a haras localizado no município de Pindodretama, e cinco amostras de animais da raça Quarto de milha provenientes de haras localizado no município de Morada Nova, ambos no Estado do Ceará.

Vale ressaltar que os equinos analisados possuíam manejo alimentar semelhante com ração comercial e feno, além do manejo sanitário que se encontrava em dia tanto a vermifugação como imunoprofilaxia para raiva, encefalomielite, tétano, influenza e herpes vírus.

Os animais foram avaliados clinicamente observando-se o estado geral, histórico, priorizando-se o exame físico do sistema genital (prepúcio, pênis e testículos) e posteriormente foram submetidos a exame andrológico, o qual compreendeu a avaliação clínica geral, reprodutiva e análise do sêmen. 
Os equinos foram nomeados por letras e números referentes a raça para fins de organização e distinção de qual animal era avaliado.

\section{Coleta das amostras}

Para a coleta os animais foram submetidos ao cortejo de uma égua no estro devidamente contida (com cordas aos pés sendo amarradas ao peitoral). Como medida de contenção foi utilizado um cachimbo, quando necessário. No cortejo, quando cada animal expunha totalmente o pênis foi realizada a monta, onde o pênis era desviado para uma vagina artificial, contendo água em temperatura em torno de $42^{\circ} \mathrm{C}$, simulando a temperatura da vagina da égua. Logo em seguida as amostras foram encaminhadas para processamento e análise.

\section{Processamento e análises das amostras de sêmen equino}

Cada ejaculado coletado foi analisado primeiramente quanto ao volume, cor, aspecto (leitoso, fluido, transparente, vermelho), odor (sui generis ou não), os quais foram registrados em planilhas de excel previamente impressas. Após esta análise física, as amostras de sêmen foram filtradas para diminuir a sujidade presentes, e logo em seguida analisadas para avaliação de vigor e motilidade e após confecção das lâminas.

\section{Avaliação de Vigor e Motilidade}

Com uso de luvas estéreis, de cada amostra de sêmen fresco, foi retirada uma alíquota de $5 \mu \mathrm{L}$ e colocada entre lâmina e lamínula para avaliação da motilidade $(0-100 \%)$ e vigor 0-5, à microscopia óptica nos aumentos de 10x e 40x. Em seguida, foi confeccionada outra lâmina com amostra diluída de cada sêmen com o Botusemen ${ }^{\circledR}$, na diluição de 2:1 ( $30 \mathrm{ml}$ de diluente para $15 \mathrm{ml}$ de sêmen), onde foram observadas as mesmas características seminais de motilidade e vigor.

\section{Avaliação morfológica espermática}

Para avaliação morfológica da cabeça, acrossoma e peça intermediaria dos espermatozoides foram separadas alíquotas de $10 \mu \mathrm{L}$ de cada amostra de sêmen e adicionadas de $1 \mathrm{~mL}$ de água. A partir dessas diluições, com auxílio de micropipeta semiautomática de 20 
$\mu \mathrm{L}$, a solução foi disposta em 3 lâminas para confecção de esfregaços que foram secos ao ar e logo em seguida corados pelos corantes panotico rápido e eosina-nigrosina. Após a coloração, as lâminas foram analisadas em microscópio óptico nos aumentos de 4x, 10x, 40x e 100x, sendo que para este último aumento foi utilizado óleo de imersão para uma melhor visualização e interpretação.

\section{Análise estatística}

De posse dos dados, os mesmos foram tabulados em planilhas eletrônicas para posterior análise tabular e gráficas através de uma análise descritiva que envolveu as médias dos valores obtidos por corante por grupo.

\section{RESULTADOS E DISCUSSÃO}

As amostras de sêmen foram analisadas a olho nu quanto ao aspecto, odor e coloração, apresentando aspecto leitoso, odor sui generis, coloração branca, estando dos padrões normais para a referida espécie.

Dos 10 equinos utilizados, foram obtidos 2 mil espermatozoides para análise de vigor e motilidade, além da avaliação morfológica. Para cada animal foram confeccionadas duas lâminas com os corantes eosina-nigrosina, considerado o padrão ouro, e o panótico rápido, nos quais foram avaliados $100 \mathrm{SPTZ}$ por lâmina de cada corante por meio de microscopia ótica com aumento de 100x.

\section{Avaliação de Vigor e Motilidade}

As análises de vigor e motilidade são muito importantes para avaliação da viabilidade dos espermatozoides numa amostra de sêmen. $\mathrm{O}$ vigor, expresso em escala de 0 a 5 , representa intensidade do movimento dos espermatozoides de se locomoverem de um canto para o outro (QUEIROZ, 2003), enquanto a motilidade diz respeito a porcentagem de espermatozoides moveis em amostras de sêmen (HAFEZ, 2004; CBRA, 1998), sendo este um dos parâmetros mais utilizados na análise do sêmen fresco tanto em laboratórios quanto em propriedades.

De acordo com as observações com padrões de estimativa, as amostras dos equinos nesse experimento apresentaram vigor de 2 a 4 , e percentuais de motilidade que variaram de $65 \%$ a $85 \%$. Tanto a motilidade total quanto o vigor espermático apresentaram valores 
semelhantes aos observados por Costa et al. (2014), Candeias (2010) e Oliveira (2010), os quais observaram motilidade $>70,0 \%$ e vigor $\geq 3$.

\section{Avaliação morfológica espermática}

A morfologia espermática é um dos principais parâmetros para predizer a capacidade fecundativa do animal, observando sua qualidade espermática, sendo esta técnica capaz de observar as patologias do sêmen, podendo também presumir se o animal e apto ou inapto para escolha de ser garanhão (KAVAK et al., 2004). Garanhões de alta fertilidade com constância de serviços de inseminação artificial ou monta controlada tem uma baixa frequência de patologias de morfologia seminal (ROUSSET et al., 1997).

$\mathrm{Na}$ avaliação morfológica, foram analisadas as alterações morfológicas de cabeça, peça intermediária e cauda observadas nas amostras seminais coradas nos corantes eosinanigrosina e panótico rápido.

$\mathrm{Na}$ avaliação de cabeça, as principais alterações observadas foram cabeça dupla, cabeça piriforme, cabeça estreita na base, contorno anormal de cabeça, contorno anormal de cabeça e cabeça dupla, sendo visualizadas no corante eosina-nigrosina (Fig. 01) e panótico rápido (Fig. 02).

Figura 01 - Avaliação de alterações de cabeça em espermatozoides equinos visualizadas no corante eosina- nigrosina. Cabeça dupla (A), cabeça piriforme (B) e cabeça estreita na base

(C)

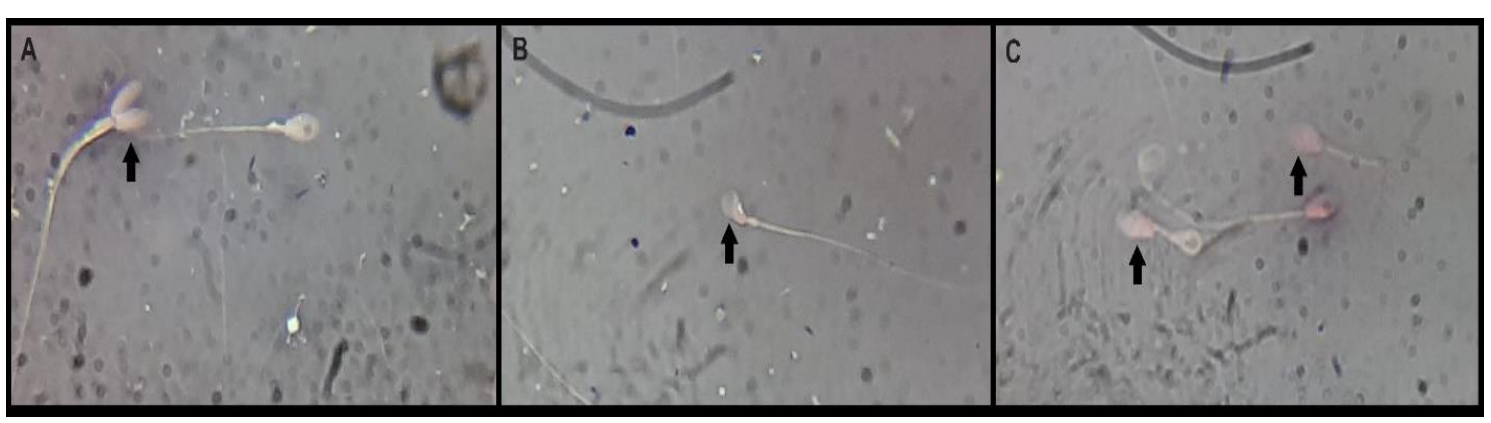

Fonte: Autores 
Figura 02: Avaliação de alterações de cabeça em espermatozoides equinos visualizadas no corante panótico rápido. Contorno anormal de cabeça (A), contorno anormal de cabeça (B) e cabeça dupla $(\mathrm{C})$

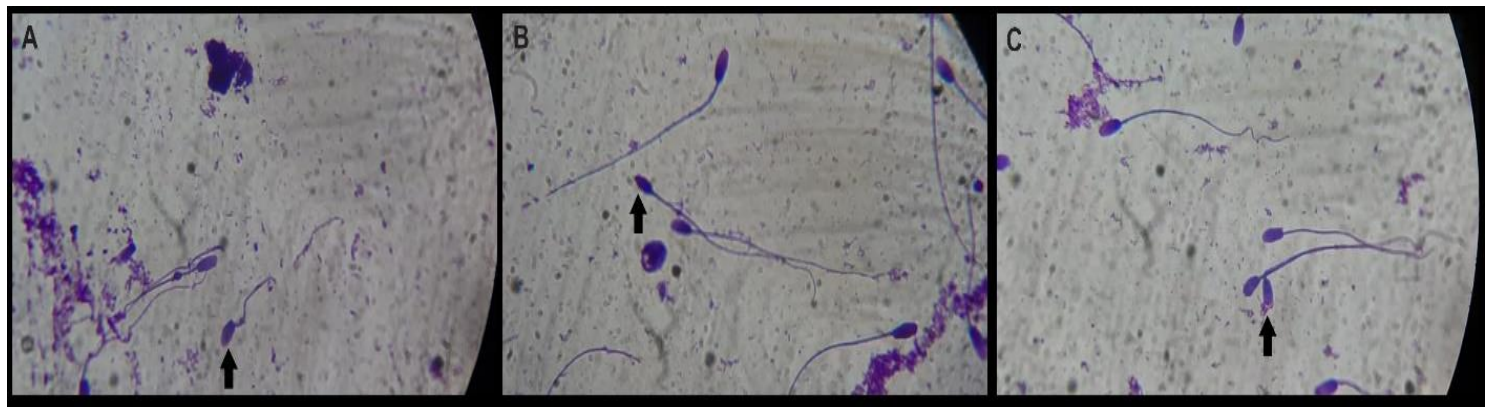

Fonte: Autores

Quanto às análises morfológicas de peça intermediária, as principais alterações visualizadas foram pseudo gota, peça intermediária estreita na base e peça intermediária em saca rolha, sendo visualizadas no corante eosina-nigrosina (Fig. 03) e panóptico rápido (Fig. 04).

Figura 03 - Avaliação de alterações de peça intermediária em espermatozoides equinos visualizadas no corante eosina-nigrosina. Pseudo gota (A e B) e peça intermediária estreita na base $(\mathrm{C})$

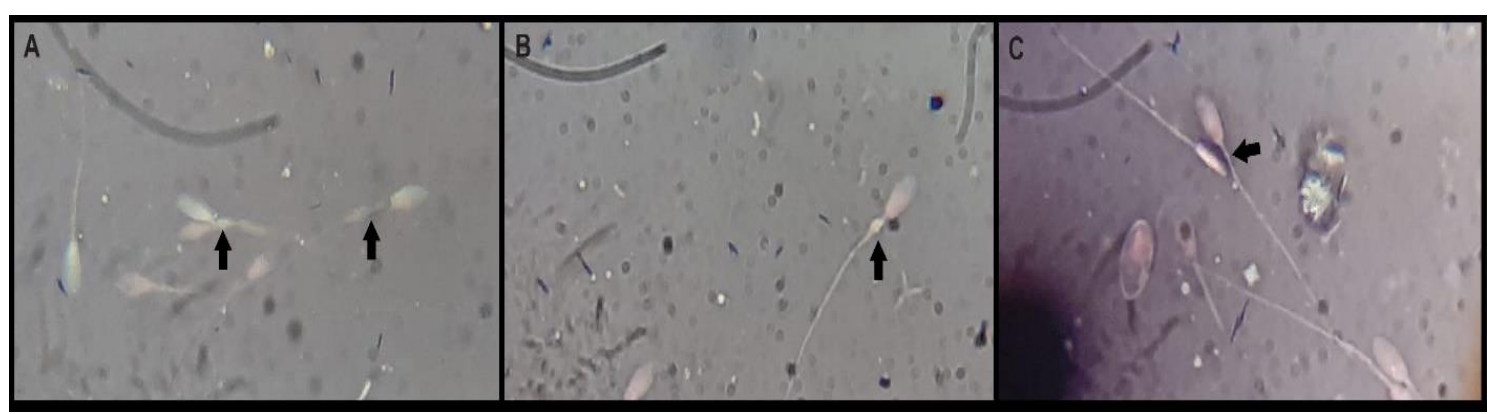

Fonte: Autores 
Figura 04: Avaliação de alterações de peça intermediária em espermatozoides equinos visualizadas no corante panótico rápido. Pseudo gota e peça intermediária em saca rolha (A) e gota distal (B)

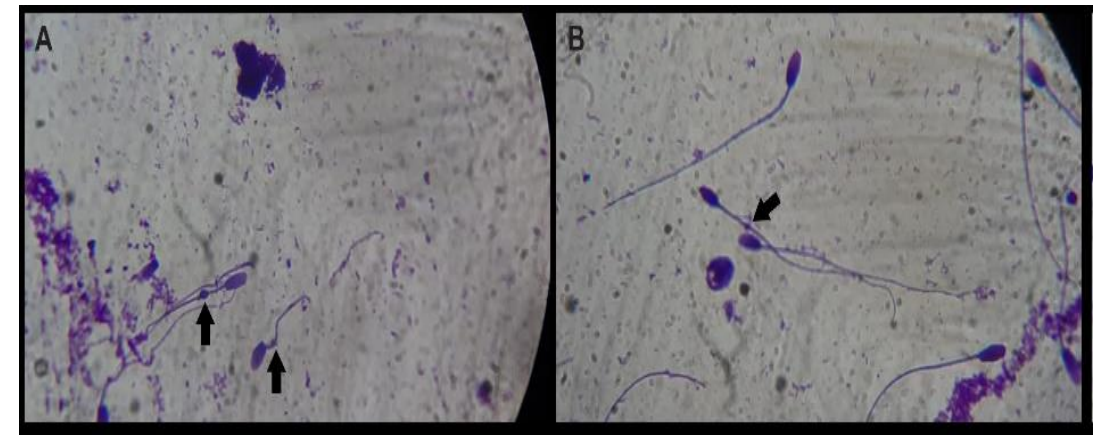

Fonte: Autores

Já com relação às alterações de cauda espermática, as principais observações foram cauda rompida, cauda enrolada e cauda fortemente enrolada, sendo visualizadas no corante eosina-nigrosina (Fig. 05) e panóptico rápido (Fig. 06).

Figura 05 - Avaliação de alterações de cauda em espermatozoides equinos visualizadas no corante eosina-nigrosina. Cauda rompida (A), cauda enrolada (B) e cauda fortemente enrolada $(\mathrm{C})$

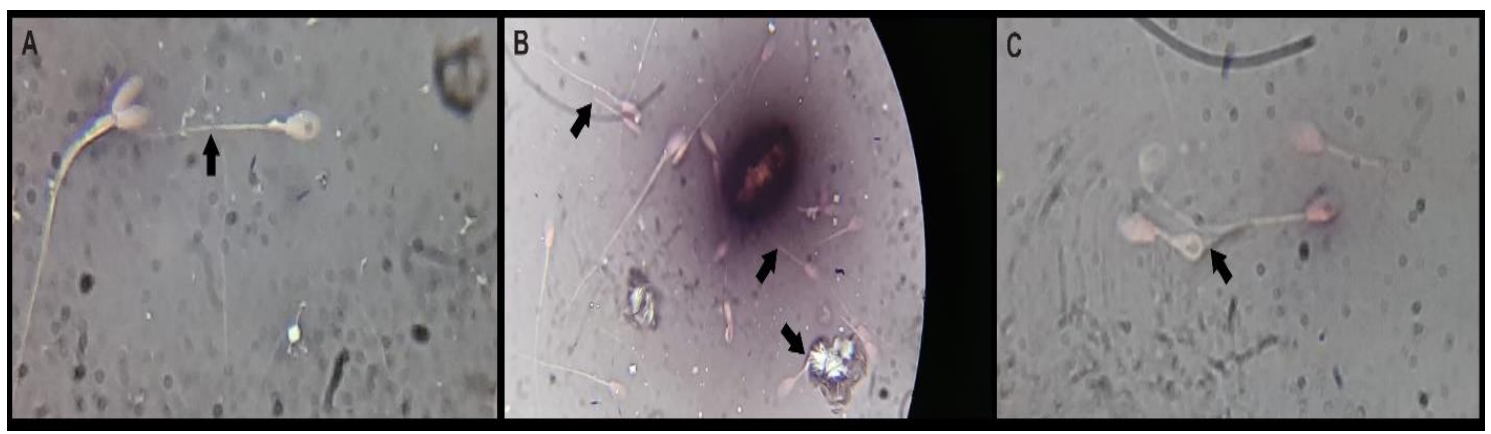

Fonte: Autores 
Figura 06 - Avaliação de alterações de cauda em espermatozoides equinos visualizadas no corante panótico rápido. Cauda rompida (A e B) e cauda fortemente enrolada (C)

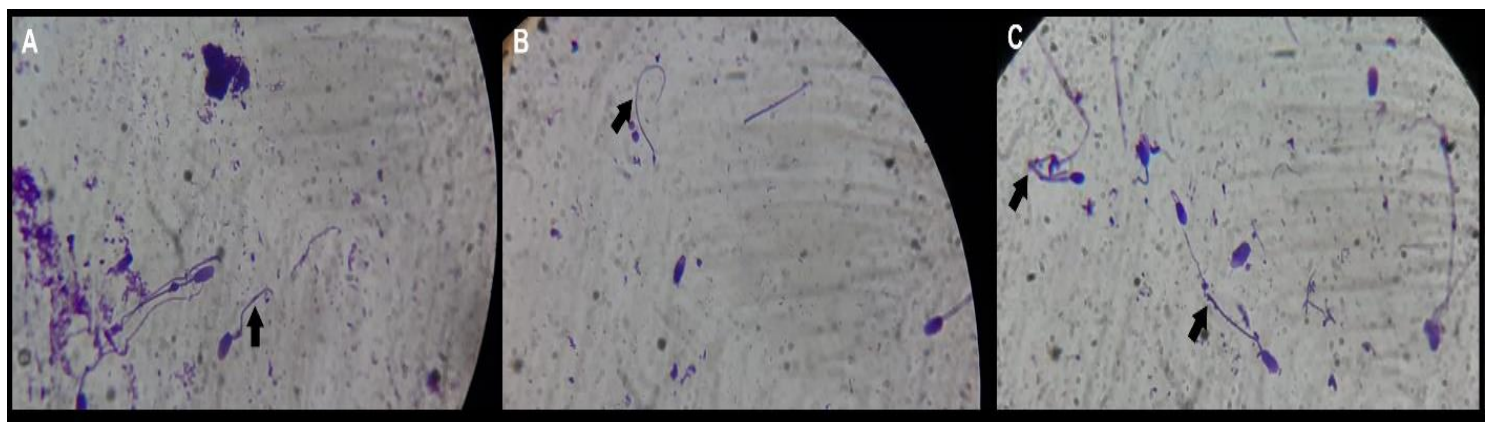

Fonte: Autores

Após a leitura das lâminas, as patologias encontradas foram catalogadas por animal em percentagem para os dois corantes. Sendo os dados encaminhados para a estatística onde foi realizada a média dos mesmos, conforme descrito nas tabelas 01,02 e 03 a seguir.

Tabela 01 - Percentual de alterações morfológicas de cabeça em amostras resfriadas de sêmen de equinos Mangalarga Marchador (MM) e Quarto de Milha (QM) coradas pelos corantes eosina-nigrosina e panótico rápido

\begin{tabular}{lcc}
\hline Animais & Eosina-nigrosina & Panótico rápido \\
\hline MM1 & $07 \%$ & $09 \%$ \\
MM3 & $25 \%$ & $10 \%$ \\
MM4 & $13 \%$ & $07 \%$ \\
MM5 & $08 \%$ & $32 \%$ \\
QM1 & $30 \%$ & $05 \%$ \\
QM2 & $04 \%$ & $12 \%$ \\
QM3 & $12 \%$ & $03 \%$ \\
QM4 & $05 \%$ & $07 \%$ \\
QM5 & $07 \%$ & $12 \%$ \\
\hline
\end{tabular}

Fonte: Dados da pesquisa 
Os valores obtidos da média no grupo dos MM foram de 17\% para o corante eosina nigrosina e de 16\% relativo ao corante panótico rápido. Já em relação ao grupo QM o valor obtido foi semelhante para os dois corantes, sendo a média de $8 \%$.

Tabela 02 - Percentual de alterações morfológicas de peça intermediária em amostras resfriadas de sêmen de equinos Mangalarga Marchador (MM) e Quarto de Milha (QM) coradas pelos corantes eosina nigrosina e panótico rápido

\begin{tabular}{ccc}
\hline Animais & Eosina-nigrosina & Panótico rápido \\
\hline MM1 & $3 \%$ & $3 \%$ \\
MM2 & $7 \%$ & $5 \%$ \\
MM3 & $5 \%$ & $3 \%$ \\
MM4 & $3 \%$ & $5 \%$ \\
MM5 & $8 \%$ & $7 \%$ \\
QM1 & $2 \%$ & $2 \%$ \\
QM2 & $3 \%$ & $5 \%$ \\
QM3 & $3 \%$ & $3 \%$ \\
QM4 & $2 \%$ & $2 \%$ \\
QM5 & $2 \%$ & $2 \%$ \\
\hline
\end{tabular}

Fonte: Dados da pesquisa

Os valores obtidos no grupo MM mostraram-se semelhantes nos dois corantes, com uma média de 5\% de alterações visualizadas. Já o grupo QM apresentou uma pequena variação onde a eosina nigrosina $(2 \%)$ nessas leituras mostrou-se inferior em relação ao panótico rápido $(3 \%)$. 
Tabela 03: Percentual de alterações morfológicas de cauda em amostras resfriadas de sêmen de equinos Mangalarga Marchador (MM) e Quarto de Milha (QM) coradas pelos corantes eosina-nigrosina e panótico rápido.

\begin{tabular}{ccc}
\hline Animais & Eosina-nigrosina & Panótico rápido \\
\hline MM1 & $09 \%$ & $12 \%$ \\
MM2 & $16 \%$ & $22 \%$ \\
MM3 & $20 \%$ & $25 \%$ \\
MM4 & $04 \%$ & $03 \%$ \\
MM5 & $25 \%$ & $31 \%$ \\
QM1 & $13 \%$ & $13 \%$ \\
QM2 & $18 \%$ & $23 \%$ \\
QM3 & $05 \%$ & $07 \%$ \\
QM4 & $09 \%$ & $11 \%$ \\
QM5 & $05 \%$ & $07 \%$ \\
\hline
\end{tabular}

Fonte: Dados da pesquisa

$\mathrm{Na}$ avaliação dos dados das patologias de cauda, foi observada variação nos dois grupos. Em relação ao MM, a média da eosina nigrosina foi de $15 \%$, enquanto do panóptico rápido foi de 19\%. No grupo QM os resultados vistos pela eosina nigrosina forma de $10 \% \mathrm{e}$ no panótico rápido $12 \%$.

Não houve diferença estatística significativa entre a média dos dados referentes aos corantes e a capacidade de visualização das patologias nas três estruturas estudadas. Vale ressaltar que não foi realizado desvio padrão e coeficiente de variação devido ao número de animais cedidos para realização do trabalho podendo haver uma margem de erro relativamente grande.

Os achados de patologias de cabeça e peça intermediária foram visualizados tanto no corante eosina nigrosina quanto no panótico rápido. Já as alterações da cauda foram observadas com maior clareza no panótico rápido, tendo uma melhor visualização do flagelo, visto que por sua capacidade tintorial tem-se uma melhor visibilidade da célula por completo, porém não diferindo espermatozoides viáveis e inviáveis sendo esta capacidade de avaliação de integridade da eosina nigrosina. 
Dessa forma, o corante panótico rápido mostrou-se eficaz, pois na avaliação de cabeça, peça intermediaria e cauda, os mesmos foram visualizados perfeitamente. Já o corante eosina nigrosina, mostrou-se como padrão a fácil visualização dos SPTZ com danos a sua integridade, onde não é perceptível no panótico, pois o corante distado no início tem capacidade de diferir com seu poder tintorial os espermatozoides com defeituosa sendo estes corados em rosa, quanto aos íntegros corados em branco conforme relatado por Foester et al. (2011).

Um estudo realizado por Arruda et al. (2015), retrata que em touros com alta fertilidade as alterações de cabeça dos espermatozoides estão entre 10 e 12\%, não excedendo $20 \%$, relata também, que não pode ultrapassar 3\% de gota proximal. Araujo e Araujo (2011), descreveram que os animais do seu estudo apresentaram defeitos de patologias com percentual de patologias acima do preconizado pela CBRA para comercialização, retratando que os animais analisados se for sub férteis os seus descendentes podem herdar esta característica.

$\mathrm{Na}$ rotina clinica dos laboratórios de patologia clínica os corantes panótico e Giemsa são os mais utilizados devido ao baixo custo e por possibilitarem a avaliação de várias células (TEIXEIRA et al., 2010; MAGALHÃES et al., 2001) devido a capacidade tintorial para avaliações características e nucleares e ainda assim uma fácil percepção e diferenciação de núcleo e citoplasma (LEME e PAPA 2010).

Por essa razão vem sendo frequentemente utilizado para a avaliação de células de linhagem espermatogênica, principalmente espermatócitos secundários e na avaliação de células testiculares em onça pintada (Panthera onça) (PAZ et al., 2003) e bovinos (BASTOS et al., 2015). Também tem sido utilizado em avaliações seminais com a análise morfológica e percentual de células espermáticas de cachorro do mato (Cerdocyun thous) (SOUZA et al., 2011). Em clínicas de pequenos animais é bastante comum a utilização desse corante para observação de citologias de líquido seminal de cães com prostatite com intuito de monitorar e prevenir a doença (STELLA et al., 2007).

O corante panótico rápido mostrou qualidade no esfregaço de sêmen equino, possibilitando a visualização das alterações morfofisiológicas do sêmen, sendo uma técnica rápida, prática e barata conforme descrito por CHARCUR et al. (2012). 


\section{CONCLUSÕES}

O panótico rápido pode ser utilizado na rotina de avaliação morfológica de espermatozoides equinos, sendo uma coloração rápida, de custo acessível e eficaz na identificação de patologias das células espermáticas, podendo ser utilizada em programas de reprodução equina.

\section{REFERÊNCIAS}

AMANN, R, P; GRAHAM, J, K. Spermatozoal Function. In: McKINNON, A.O. et al. Equine reproduction. John Wiley \& Sons, 2011. 1053-1084 p.

ARRUDA, R.P.; SILVA, D.F.; AFFONSO, F.J.; LEMES, K.M; JAIMES, J.D.; CELEGHINI, E.C.C.; ALONSO, M.A.; CARVALHO, H.F.; OLIVEIRA, L.Z.; NASCI, J. Métodos de avaliação da morfologia e função espermática: momento atual e desafios futuros. Rev. Bras. Reprod. Anim., Belo Horizonte, v.35, n.2, p.145-151, abr./jun. 2011. Disponível em: www.cbra.org.br.

BASTOS YHGB, FERREIRA CS, GOMES GM, JR KCP, GOMES LPM, PAPA FO, CRESPILHO AM. Avaliação de diferentes técnicas de coloração para esfregaços obtidos por punção de biópsia aspirativa testicular em bovinos. Revista saúde. 6 (2): p. 05-10, 2015.

BASTOS, Y. H. G. B; FERREIRA, C.S.; GOMES, G. M.; JÚNIOR, K. D. C. P.; GOMES, L.P.D. M.; PAPA, F. O.; CRESPILHO, A. M. Avaliação de diferentes técnicas de coloração para esfregaços obtidos por punção biópsia aspirativa testicular de bovinos. Revista de Saúde 06 (2): p. 05-10, 2015.

BIELANSKI, W. The evaluation of stallion semen in aspects of fertility control and its use for artificial insemination. J. Reprod. Fertil. SUPPL. 23: p. 19-24, 1975.

BIELANSKI, W., KACZMARSKI, F. 1979: Morphology of spermatozoa in semen from stallions of normal fertility. J. REPROD. FERTIL. SUPPL. 27: 39-45.

CANDEIAS L.M. 2010. Avaliação de diferentes protocolos de criopreservação de sêmen de garanhões da raça Mangalarga Machador. Dissertação de Mestrado em Medicina Veterinária, Universidade Federal Fluminense, Niterói, RJ. 105p.

CHACUR MGM, ET AL. Season influence u seminal plasma proteins in bulls. In: international congress on animal reproduction, 15. PORTO SEGURO, v. 1, 2004.

CHACUR, M.G.M et al. Influencia da estação do ano nas características do sêmen e na concentração de hormônios em touros da raça Nelore e Simental. Arq. Bras. Med. Vet. Zootec., v. 64, n.3, p 540-546. 2012.

COLÉGIO BRASILEIRO DE REPRODUÇÃO ANIMAL - CBRA. Manual para exame andrológico e avaliação de sêmen animal. 2. ed. Belo Horizonte - MG, 1998. 49p. 
CONTRI, A., VALORZ, C., FAUSTINI, M., WEGHER, L. \& CARLUCCIO, A. (2010). Effect of semen preparation on casa motility results in cryopreserved bull spermatozoa. Theriogenology, 74(3): p. 424-435, 2010.

COSTA, D.N.M., SILVA, D.A.M., BOAKARI, W.L., FERREIRA, S.B., BRANCO, M.A.C.; SOUZA, J.A.T. Eficiência dos diluidores Tris e BotuCrio ${ }^{\circledR}$ sobre os parâmetros seminais de garanhões das raças Quarto de Milha e Mangalarga Marchador. Ciênc. Anim. Bras. 15(3): p. 322-329, 2014.

DE ARRUDA, R.P.; DE ANDRADE, A. F. C; PERES, K.R.; RAPHAEL, C. F.; NASCIMENTO, J.; CELEGHINI, E. C. C. Biotécnicas aplicadas à avaliação do potencial de fertilidade do sêmen equino. Revista Brasileira de Reprodução Animal, Belo Horizonte, v.31, n.1, p.8-16, jan./mar. 2007. Disponível em: www.cbra.org.br.

DOT'T, H. M. Morphology of stallion spermatozoa. J. Reprod. Fertil. Suppl. 23: 41-46, 1975.

DOTT, H. M., FOSTER, G. C. A technique for studying the morphology of mammalian spermatozoa which are eosinophilic in a differential 'live/dead' stain. J. Reprod. Fertil. 29: 443-445, 1972.

DOWSETT, K. F., OSBORNE, H. G., PATTIE, W. A. Morphological characteristics of stallion spermatozoa. Theriogenology 22: p.463-472, 1984.

FOSTER, M.L.; LOVE, C.C.; VARNER, D.D.; BRINSKO, S.P.; HINRICHS, K.; TEAGUE, S.; LACAZE, K.; BLANCHARD T.L. Comparison of methods for assessing integrity of equine sperm membranes. Theriogenology, v.76, p.334-41, 2011.

GRAHAM, J. K. Analysis of stallion semen and its relation to fertility. Vet. Clin. North am. Equine pract. 12: p. 119-130, 1996.

HAFEZ, E. S. E. Anatomia da reprodução masculina. In: HAFEZ, E. S. E.; HAFEZ, B. Reprodução animal. $7^{\text {a }}$ ed. Barueri: Manole, p. 3-12, 2004.

JASKO, D. J., LEIN, D. H., FOOTE, R. H. Determination of the relationship between sperm morphologic classifications and fertility in stallions: 66 CASES (1987-1988). J. Am. Vet. Med. Assoc. 197: 389-394, 1990.

JASKO, D. J., LITTLE, T. V., SMITH, K., LEIN, D. H., FOOTE, R. H. Objective analysis of stallion sperm motility. THERIOGENOLOGY 30: p. 1159-1167, 1988.

LEME DP, PAPA FO. How to perform and interpret testicular fine needle aspiration in stallions. Journal of equine veterinary Science (30): 145-148, 2010.

MAZIERO, R.R.D, et al. Analise de sêmen bovino e sua relacao com a fertilidade. In: Congresso Brasileiro de Reproduçao Animal, 18, 2009. Belo Horizonte. Anais, Belo Horizonte, CBRA 2009.

OETTLE, E. E. Using a new acrosome stain to evaluate sperm morphology. Vet. Med. March: p. 263-266, 1986. 
OLIVEIRA R.R. 2010. Efeito in vitro da incorporação de colesterol à membrana plasmática de espermatozoide de jumentos (Equus asinus) da raça Pêga. Dissertação de Mestrado em Zootecnia, Universidade Federal de Minas Gerais, Belo Horizonte, MG. 109p.

OliveirA, G. C., OliveirA, B., CELEGHINI, E. C. C., FERNANDES, C. B. \& MATTOS, C. B. Criopreservação do sêmen equino: uma revisão. Revista brasileira reprodução animal, 37(1): p. 23-28, 2013.

PAZ, R. C. R.; LEME, D. P.; ZÜGE, R. M.; PESSUTI, C.; SANTOS, E. F.; BARNABE, R. C. Citologia aspirativa por agulha fina (CAAF), em testículo de onça pintada (Panthera onca), utilizada como ferramenta no diagnóstico de infertilidade. Brazilian Journ al of Veterinary Research and Animal Science 40: p.100-107, 2003.

PAPA, F. O.; ALVARENGA, M. A..; DELl'AQUA JR, J. A.; MONTEIRO,.G. A.; SANCLER-SILVA, Y. F. R., NETO, C. R. Manual de andrologia e manipulação de sêmen equino, 2014. Disponível em: www.botupharma.com.br.

QUEIROZ, V. S. (2003). Estudo do efeito das condições de manipulação do sêmen de jaguatiricas (Leopardus pardalis, Linnaeus, 1758) sobre a capacitação e a integridade morfológica e funcional dos espermatozóides. Master of Science, Universidade de São Paulo, São Paulo, Brasil.

SOUZA NP, GUIMARÃES LDA, PAZ RCR. Dosagem hormonal e avaliação testicular em cachorro do mato (cerdocyun thous) utilizando diferentes protocolos anestesicos. Arq. Bras. Med. Vet. Zootec., v.63, n.5, p. 1224-1228, 2011.

STELLA DE FERREIRA VALLE, MARINÊS BORTOLUZZI, LUCAS MARQUES COLOMÉ, JONAS LEOPOLDINO DE SOUZA. Aspectos citológicos do fluido seminal em um canino apresentando prostatite. Acta Scientiae Veterinariae. 35(3): 393-396, 2007.

TEIXEIRA LV, LOPES STA, MARTINS DB, FRANÇA RT, FIGHERA RA. Punção aspirativa por agulha fina com metódo de coleta de material para histopatologia no osteossarcoma canino. Pesquisa Veterinária Brasileira. (21): 23-32, 2001.

VALE FILHO, V.R. Subfertilidade em touros: parâmetros para avaliação andrológica e conceito geral. Caderno Tecnico de Veterinaria e Zootecnia. Belo Horizonte: F.E.P.M.V.Z. n.35, p. 81-87, ago, 2001.

VAN DER SCHAAF, A. Vitalkleuring van stieren-sperma met een oplossing van anilineblauw en eosine. Tijdschrift voor diergeneeskunde 77: 815, 1952.

VOGLMAYR, J.K et al. The effect of heating the testis on the metabolismo os testicular spermatozoa and the testis fluid. Journal of Reproduction and Fertility, London, v.21, p.335336, 1970.

VOSS, J. L., PICKETT', B. W., SQUIRES, E. L. 1981: STALLION SPERMATOZOAL Morphology and motility and their relationship to fertility. J. Am. Vet. Med. Assoc. 178: p.287-289, 1981.

WAITES, G.M.H. Temperature Regulation and Testis. In: Jonhson, A.D, GOMES, W.R; VANDERMARK, N.L. The testis. New York. Academic press. p. 241-179, 1970. 
WOODS, J., BERGFELT, D. R.; GINTHER, O. J. Effects of time of insemination relative to ovulation on pregnancy rate and embryonic-loss rate in mares. Equine veterinary journal, 22(6): p. 410-415, 1990.

Alves, S.G., Gribeiro Filho, A.L., Snoeck, P.P.N., Chalhoub, M., Bittencourt, R.F., Portela, A.P.M., Almeida, A.K., Melo, M.I.V. e Henry, M. 2005. Efeito da solução, da fixação em formol-salina e do tempo de incubação sobre os resultados do teste hiposmótico para sêmen eqüino congelado. Ciên. An. Bras., 6: 219-225.

Araújo, A.M.S.1 e Araújo, S.A.C.2. Patologias espermáticas mais comuns em garanhões da raça pônei brasileira more common sperm phatologies in brazilian pony stallions. Recibido: 31-10-08. Aceptado:16-12-08. Arch. Zootec. 60 (229): 145-148. 2011.

Rubens Paes de Arruda ,Eneiva Carla Carvalho Celeghini1, Alexandre Rossetto Garcia2, Gabriel De Carli dos Santos1, Ticiano Guimarães Leite1, Letícia Zoccolaro Oliveira1,3, Renata Lançoni 1 , Mariana de Paula Rodrigues4. Morfologia espermática de touros: interpretação e impacto na fertilidade Bull sperm morphology: interpretation and impact on fertility. Rev. Bras. Reprod. Anim., Belo Horizonte, v.39, n.1, p.47-60, jan./mar. 2015. Disponível em www.cbra.org.br. 


\section{SOBRE OS ORGANIZADORES}

\section{Victor Hugo Vieira Rodrigues}

Possui graduação em Medicina Veterinária pela Universidade Federal Rural do Semiárido (2005), mestrado em Programa de Pós-graduação em Ciências Veterinárias pela Universidade Estadual do Ceará (2010) e doutorado em Biotecnologia pela Rede Nordeste de Biotecnologia (2016). Atualmente é professor do Centro Universitário Maurício de Nassau Fortaleza, responsável pelas disciplinas de anatomia descritiva e topográfica dos animais domésticos e da disciplina de patologia geral e técnicas de necropsia. É orientador no programa de especialização do Ifope Educacional em Minas Gerais. Além disso, é membro do corpo editorial da editora in vivo e organizador dos e-books Atualidades na Saúde e Bem-Estar Animal e Atualidades e Fundamentos na Reprodução e no Desenvolvimento. Tem experiência na área de Medicina Veterinária, com ênfase em embriologia, biotécnicas da reprodução, patologia clínica e anatomia veterinária.

CV Lattes: ttp://lattes.cnpq.br/2226604565550002

\section{Aderson Martins Viana Neto}

Doutor em Zootecnia (Produção Animal - PDIZ/UFC), Mestre em Zootecnia (Produção Animal e Melhoramento Genético - PPGZ/UFC). Graduado em Zootecnia pela Universidade Federal do Ceará. Foi Professor Substituto no Departamento de Zootecnia UFC, bolsista de apoio técnico Laboratório de Fisiologia Animal - UFC (Reprodução animal, Biotecnologias da reprodução, Proteômica, Reprodução Cunícola). Estagiário do CEACLABOMAR-UFC (Carcinicultura) e na empresa Lar Antônio de Pádua (Caprinos e bovinos leiteiros). Tem experiência na área de Zootecnia, com ênfase em Produção e Reprodução Animal, Gestão da Propriedade Rural, Bioclimatoologia e Biotecnologia. Atualmente é Professor Temporário na Universidade Estadual do Ceará (FAVET/UECE).

CV Lattes: http://lattes.cnpq.br/4682104695685941

\section{Máyra Carvalho Petelinkar}

Cursando o $8^{\circ}$ semestre de Medicina Veterinária na Universidade de Fortaleza (UNIFOR) Vice-presidente do Grupo de Estudos de Animais Silvestres da Unifor (GEAS UNIFOR) Participação no Grupo de Pesquisa em Sanidade Animal.

CV Lattes: http://lattes.cnpq.br/5981111350891482 


\section{ÍNDICE REMISSIVO}

B

Biologia reprodutiva, 97

biotécnicas reprodutivas, $8,61,70$

Biotécnicas Reprodutivas, 10

Biotecnologia, 80, 127

biotecnologias reprodutivas, 7

\section{C}

ciclo estral, 50, 51, 58, 61, 63, 65, 66, 68, 69, 70 cisto, 27, 28, 29, 30, 31, 32, 33, 34, 35, 41, 57

Clonagem, 80, 93, 94, 95, 96

Compostos, 6, 22, 46, 61, 76, 80, 97, 110

E

Espermatozoide, 110

F

fertilidade, $6,12,29,34,44,48,61,64,65,66$, $116,122,124,126$
$\mathbf{H}$

humano, 6, 7, 9

M

Morfologia, 6, 9, 43, 110, 126

motilidade, 10, 110, 112, 114, 115

\section{$\mathbf{O}$}

oócito, $6,8,9,10,11,12,13,14,15,18,54,84,89$ ovariano, 9, 28, 30, 31, 46, 49, 51, 52, 53, 56, 57, 58,59

Ovário, 27, 46, 50, 53, 56

$\mathbf{P}$

Patologia, 22, 24, 41, 42, 43

$\mathbf{T}$

tratamento hormonal, 76,78

Tumor, 47 


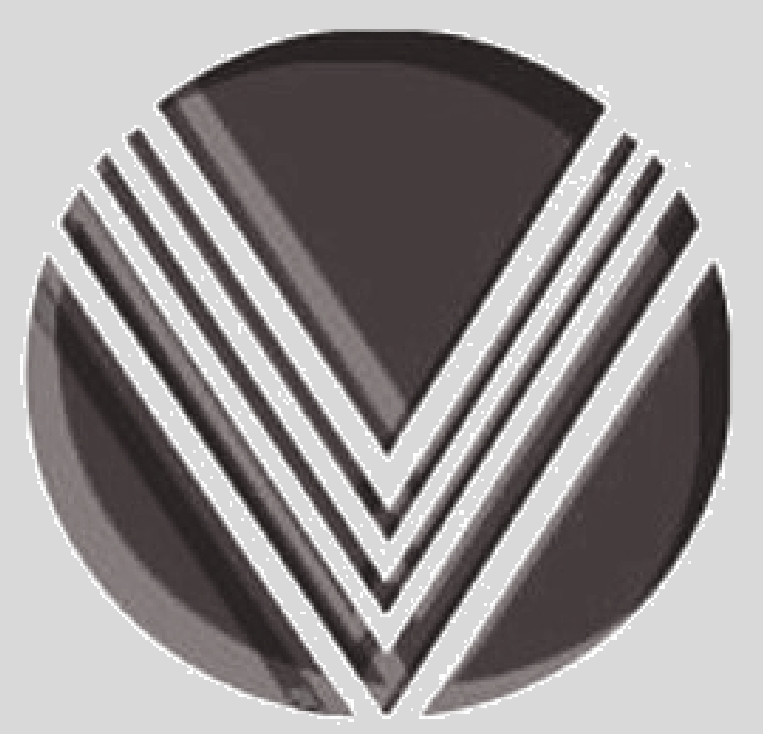

EDITORA
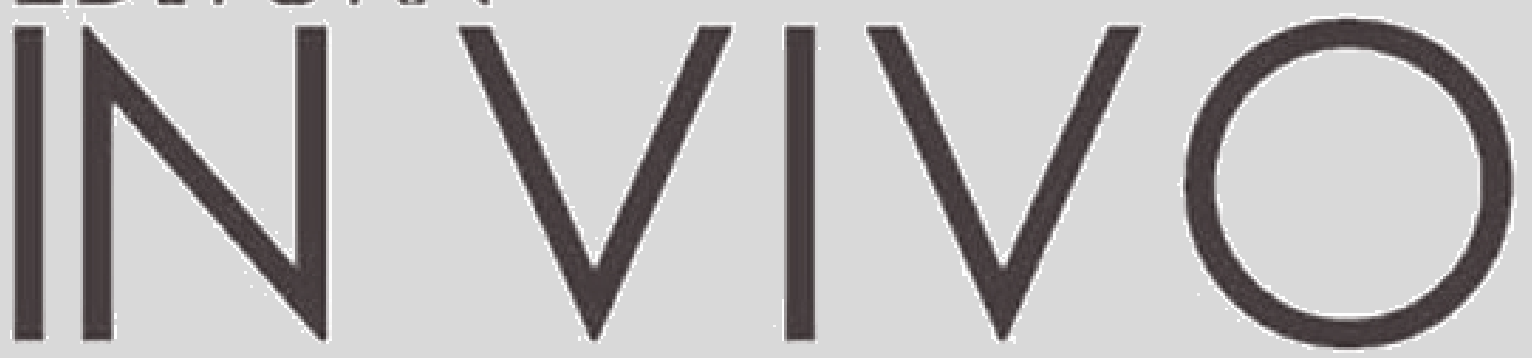

ACESSE:

www.editorainvivo.com

Avance na ciência! Venha ser In Vivo! 